\title{
CUSTO-EFETIVIDADE DA FLUORETAÇÃO DAS ÁGUAS DE ABASTECIMENTO PÚBLICO NO MUNICÍPIO DE SÃO PAULO, NO PERÍODO DE 1985-2003
}

\section{ANTÔNIO CARLOS FRIAS}

\begin{abstract}
Tese apresentada ao Programa de Pós-graduação em Saúde Pública da Universidade de São Paulo, para obtenção do título de Doutor em Saúde Pública
\end{abstract}

Área de Concentração: Serviços de Saúde Pública

Orientador: PROF. DR. PAULO CAPEL NARVAI

São Paulo 2004

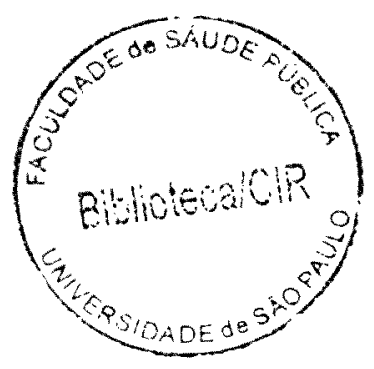




$$
45090 / 2064 \text { doe }
$$

Autorizo, exclusivamente para fins acadêmicos e cientificos, a reproduçăo total e parcial desta dissertaçăo, por processos fotocopiadores,

Assinatura:

Data. 
Caminhante, são tuas pegadas o caminho, e nada mais; caminhante, não há caminho o caminho se faz ao andar.

Ao andar se faz o caminho, e ao voltar a vista atrás vê-se a senda que nunca se voltará a pisar.

Caminhante, não há caminho há apenas sulcos no mar 
Aos meus pais,

OSWALDO \& CLEONICE

Pois me proporcionaram a dádiva divina da vida.

Para minha esposa e filhas,

MARISTELA, BRENDA, LARA e LIZ

Mulheres que preenchem minha vida de amor, dedicação,

afeto e felicidade. 
Dedico especialmente esta tese em homenagem ao

Prof. Dr. ALFREDO REIS VIEGAS (in memoriam)

Sábio mestre que dedicou sua vida a docência e a pesquisa na FSP-USP para a formação de muitas gerações de Sanitaristas, e um eterno defensor da fluoretação da águas de abastecimento público neste país. 


\section{AGRADECIMENTOS}

Ao Prof. Dr. Paulo Capel Narvai, pela amizade e a confiança depositada em mim, por sua visão de mestre que soube impor desafios sabendo do meu potencial para supera-los, e impulsionar-me a novas descobertas.

Ao Prof. Eng. Alexandre Saron, pelo companheirismo, presteza e o seu entusiasmo por esta pesquisa, além de ser fundamental dentro da SABESP pelo acesso a diversos documentos e relatórios que foram necessários para execução deste trabalho.

A Thomas G Reeves, P.E. National Fluoridation Engineer of CDC, por seu empenho e presteza no fornecimento de material sobre os sistemas de fluoretação empregados pelo CDC.

A Prof?. Maristela Vilas Boas Fratucci, por sua dedicação, pelas muitas leituras e conferências da pesquisa para que as minhas idéias pudessem ser materializadas de forma clara.

Ao Prof. Celso Zilbovicius, pela grande amizade, companheirismo, ajuda nas incansáveis traduções, nas discussões de idéias, e por absorver parte da demanda dos inúmeros trabalhos ao qual eu tive que me ausentar para dedicar a tese.

A Profa. Simone Rennó Junqueira, por sua amizade e dedicação nas leituras e discussão das idéias que foram surgindo para o desenrolar da tese.

A Prof Dra. Maria Ercilia de Araújo, pela amizade, pelo incentivo, por seus sábios conselhos em nossas conversas que foram fontes de inspiração para a condução dos trabalhos.

Ao Prof. Dr. Roberto Augusto Castellanos Fernandes, por sua paciência, seus sábios conselhos e o seu espírito terno, jovial e alegre que conduz com maestria as dificuldades da jornada. 
A Profe. Dra. Maria do Rosário Dias de Oliveira Latorre, por sua dedicação e didática das aulas, que traz a luz da compreensão questões complexas em estatística com uma sabedoria divina, por me ajudar a superar dificuldades que encontrei no campo da estatística.

Ao Prof. Dr. José Leopoldo Antunes, por sua determinação e sabedoria na condução das conversas para clarear as idéias e concretização deste trabalho.

Ao Prof. Elyseo Cícero dos Santos, por sua amizade e ajuda no esclarecimento dos periodos de instabilidade econômico-financeira que 0 Brasil enfrentou, contribuindo assim no ajuste dos cálculos econômicos da pesquisa.

A todos os Professores da Faculdade de Saúde Publica da Universidade de São Paulo e os Professores do Departamento de Odontologia Social da USP pela dedicação na transmissão de conhecimentos. 


\section{RESUMO}

Frias AC. Custo-Efetividade da fluoretação das águas de abastecimento público no município de São Paulo, no período de 1985-2003. São Paulo; 2004. [Tese de Doutorado - Faculdade de Saúde Pública da Universidade de São Paulo].

Esta pesquisa tem como objeto o custo e a efetividade de 18 anos de fluoretação das águas de abastecimento público no municipio de São Paulo no periodo de 1985 a 2003. Avalia-se a mudança do quadro epidemiológico da cárie dentária, o controle dos teores de flúor, o custo da fluoretação e o benefício proporcionado à população sendo projetado o custo-efetividade per capitalano. Para o cálculo da composição de custos da fluoretação das águas levou-se em conta: o custo de capital inicial de instalação, o custo do produto químico (ácido fluorsilicico), o custo de operacionalização do sistema (manutenção do sistema, energia elétrica e recursos humanos) e o custo de controle. Constatou-se que neste periodo a população foi exposta a teores adequados de flúor $(0,7 \mathrm{ppm})$. A ação do flúor mostrou-se eficaz, pois para a idade de 12 anos observou-se redução de $73 \%$ na prevalência de cárie dentária, sendo que em 1986 a média do índice CPO-D era de 6,47 $(6,12-6,82)$, e em 2002 foi de $1,75(1,48-2,92)$. Nesta idade-indice, $40 \%$ das crianças apresentaram CPO-D $=0$ em 2002. O custo médio per capita/ano na cidade de São Paulo foi de R\$ 0,08 (US\$ 0,03) em 2003. O custo acumulado em 18 anos de implantação do sistema de fluoretação, foi de $R \$$ 1,44 (US\$ 0,94) per capita. A análise do benefício/custo da fluoretação, apenas para o grupo etário de 7 a 12 anos, indica uma economia de custos da ordem de $\mathrm{R} \$ 348,68$ (US\$ 113,95) no serviço privado e de $\mathrm{R} \$ 83,68$ (US\$ $27,35)$ no serviço público por habitante/ano. A simulação de custos para comunidades, segundo o número de habitantes, foi de R\$ 0,46 (US\$ 0,15) para populações até 5.000 habitantes; de $R \$ 0,27$ (US\$ 0,09) para 5.001 a 10.000 habitantes; de $R \$ 0,17$ (US\$ 0,05) para 10.001 a 20.000 habitantes; de $R \$ 0,12$ (US\$ 0,04) para 20.001 a 50.000 habitantes; e de $R \$ 0,09$ (US\$ $0,03)$ para 50.001 a 100.000 habitantes. Tais valores são considerados relativamente baixos para uma intervenção de saúde pública com o impacto referido.

\section{PALAVRAS-CHAVES:}

Custo-efetividade. Custo-benefício. Fluoretação de águas. Cárie dentária. 


\section{ABSTRACT}

Frias, AC. Custo-Efetividade da fluoretação das águas de abastecimento público no município de São Paulo, no período de 1985-2003. [Costeffectiveness of fluoridation of public water supply in the city of São Paulo, in the period of 1985-2003]. São Paulo [BR]; 2004. [PhD Thesis - Faculdade de Saúde Pública da Universidade de São Paulo Brazil].

This research has as object of study the cost and effectiveness of 18 years of fluoridation of public water supply system in the city of São Paulo, Brazil during the period 1985-2003. It is evaluated the change in the epidemiological status of dental caries, control of fluoride level in the water supply, costs of fluoridation and benefits rendered to the population and costeffectiveness has been projected per capita/year. For calculation of costs of fluoridation of the public water supply the following components were taken into account:: the initial capital cost of installation, the cost of chemical product (hydrofluosilicic acid), the system operation cost (system maintenance, electrical energy and human resources) and the control cost. It has been observed that population has been exposed to appropriate levels of fluoride $(0.7 \mathrm{ppm} F)$ during this period. The addition of fluoride has been effective as, for the age of 12 years, it has been observed a decrease of $73 \%$ in the prevalence of dental caries years - the mean of the DMF index was $6.47(6.12-6.82)$ in 1986 and in 2002 the mean was $1.75(1.48-2.92)$. For this age index, $40 \%$ of the children presented DMF $=0$ in 2002 . The average cost per inhabitant/year for the year 2003 was R\$ 0,08 (US\$ 0.03). The accumulated cost for 18 years of implantation and maintenance of the fluoridation system was R\$ 1,44 (US\$ 0.94 ) per capita. The analysis of benefit-cost of fluoridation, only for the group of schoolchildren ranging from 7 to 12 years old showed an economy of R\$348.68 (U\$ 113.95) in treatment at the private clinic and R\$83.68 (US\$27.35) at the public system per habitant/year. The simulation of costs to communities according the population revealed a cost of $R \$ 0.46$ (US $\$ 0.15$ ) per inhabitant in a community with less than 5,000 inhabitants; R\$ 0.27 (US\$ 0.09) per inhabitant in communities with populations ranging from 5,001 to 10,000 inhabitants; R\$ 0.17 (US\$ 0.05) per inhabitant in communities with populations ranging from 10,001 to 20,000 habitants; R\$ 0.12 (US\$ 0.04 ) per inhabitant in communities with populations ranging from 20,001 to 50,000 inhabitants; and R\$ 0.09 (US\$ 0.03) per inhabitant in communities with populations ranging from 50,001 to 100,000 inhabitants. These values are considered relatively low for an intervention in public health that presents the related impact.

KEYWORDS:

Cost-effectiveness. Cost-benefit. Water fluoridation. Dental caries. 


\section{ÍNDICE}

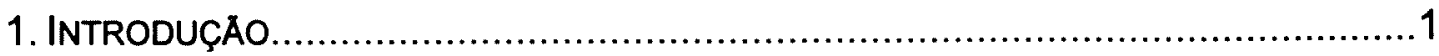

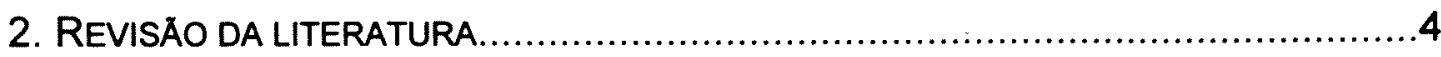

2.1 Águas de ABASTECIMENTO e FlUORETAÇAo..................................

2.2 FluoretaçAo Artificial das Águas de ABASTECIMENTO..................7

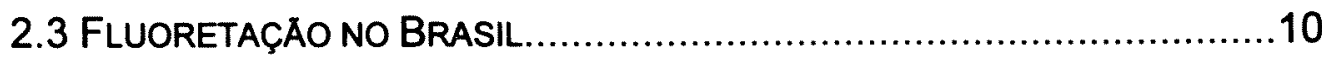

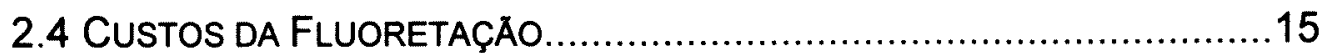

2.5 ÍNDICE CPO-D E FATORES SÓCIO-ECONÓMICOS..............................35

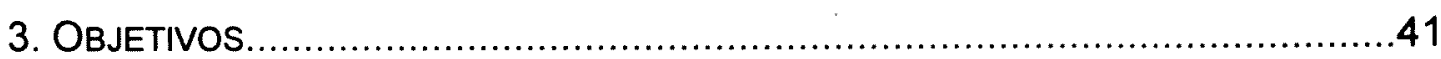

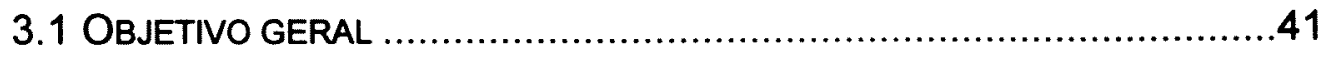

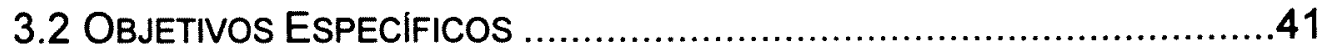

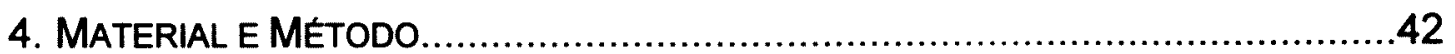

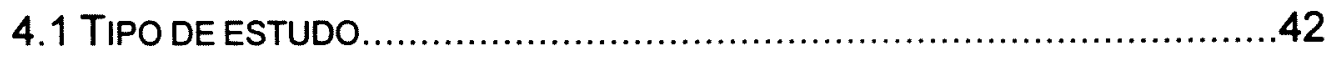

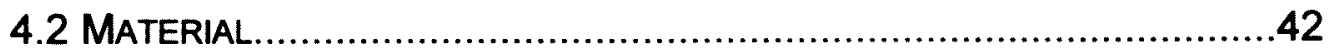

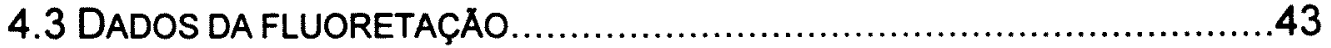

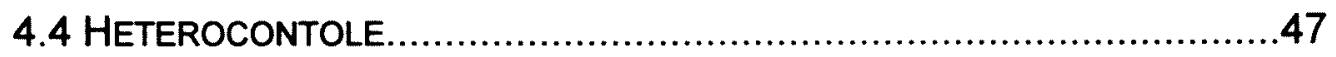

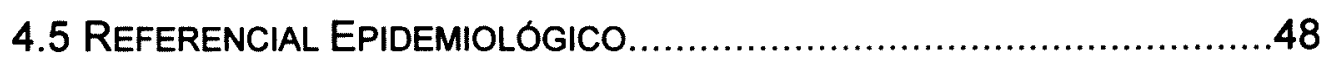

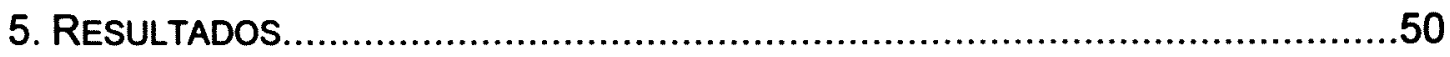

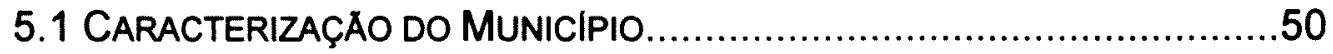

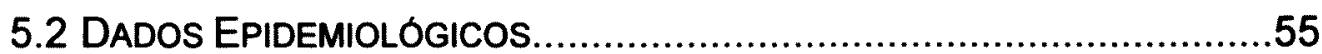

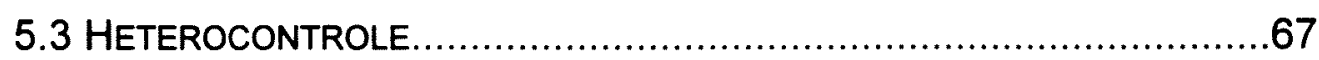

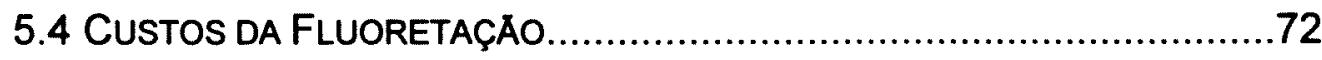

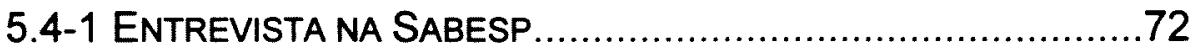

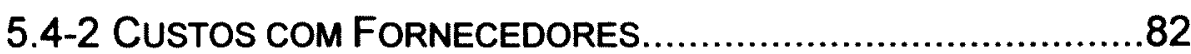




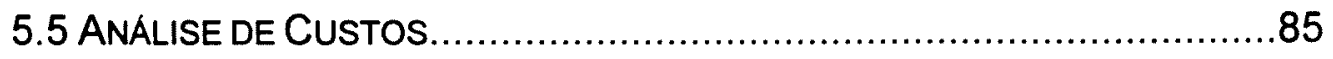

5.5-1 Custo de CAPITAL INICIAL DE INSTALAÇÃo..........................85

5.5-2 CUSTO do PRODUTO QUIMICO..........................................8

5.5-3 CUSTO DE OPERACIONALIZAÇÃo do SISTEMA.......................89

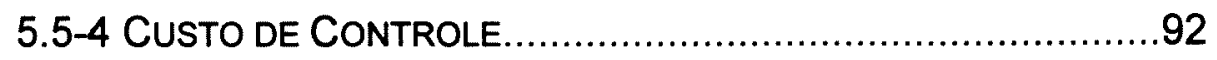

5.5-5 Custos dA FLUORETAÇÃo da ÁguA No Sistema dE

Tratamento no Municipio de Sáo PaUlo.........................92

5.6 SIMULAÇÃo dE CUSTOS PARA IMPLANTAÇÃo dE UM SISTEMA DE

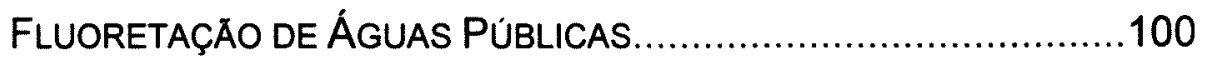

5.7 A RELAÇÃo BENEFICIO/CUSTO dA FLUORETAÇÃo............................108

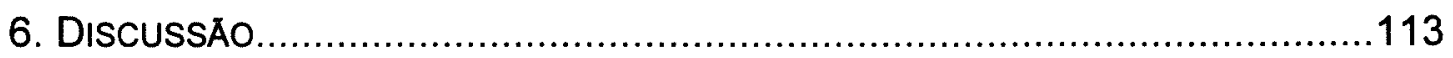

6.1 FluORETAÇÃo No MUNICIPIO de SÃo PAULO..................................114

6.2 ANÁLISE dOS CUSTOS DA FLUORETAÇÃo........................................121

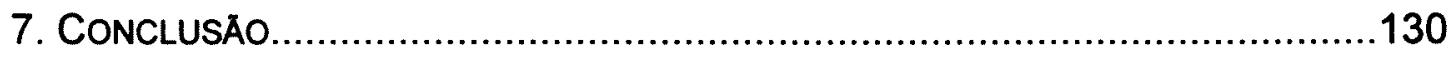

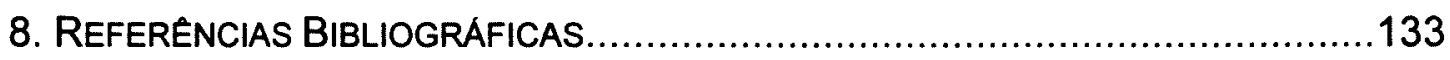

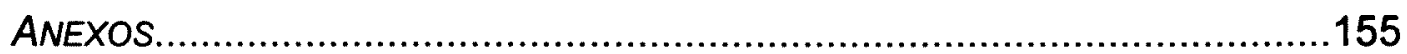




\section{INDICE DE QUADROS, FIGURAS E TABELAS}

\section{QUADROS}

Quadro-1 Componentes da equação de custo-efetividade proposto por WEINSTEIN E STASON (1977)

Quadro-2 Componentes e resultados da equação de cálculo de custos proposto por RINGELBERG et al (1992).

Quadro-3 Componentes e resultados da equação de economia de custo da fluoretação da água proposta por HADDIX (1996)

\section{FIGURAS}

Gráfico 5.1 - Média do índice CPO-D, Limite Inferior e Limite Superior do IC $\mathrm{C}_{95}$ para a média populacional, na idade de 7 anos de 1969 a 2002.

São Paulo .58

Gráfico 5.2 - Média do indice CPO-D, Limite Inferior e Limite Superior do $\mathrm{IC}_{95 \%}$ para a média populacional, na idade de 8 anos de 1969 a 2002. São Paulo.

Gráfico 5.3 - Média do índice CPO-D, Limite Inferior e Limite Superior do IC $\mathrm{C}_{95}$ para a média populacional, na idade de 9 anos de 1969 a 2002. São Paulo. 60

Gráfico 5.4 - Média do índice CPO-D, Limite Inferior e Limite Superior do $\mathrm{IC}_{95 \%}$ para a média populacional, na idade de 10 anos de 1969 a 2002. São Paulo.

Gráfico 5.5 - Média do indice CPO-D, Limite Inferior e Limite Superior do IC $\mathrm{C}_{95 \%}$ para a média populacional, na idade de 11 anos de 1969 a 2002. São Paulo. 
Gráfico 5.6 - Média do índice CPO-D, Limite Inferior e Limite Superior do $\mathrm{IC}_{95 \%}$ para a média populacional, ma idade de 12 anos de 1969 a 2002. São Paulo.

Gráfico 5.7 - Porcentagem de crianças com CPO-D = Zero, Limite Inferior e Limite Superior do $\mathrm{IC}_{95 \%}$ para a média populacional para idade de 12 anos de 1969 a 2002. São Paulo. 66

Gráfico 5.8 - Resultado do heterocontrole de flúor nas amostras das águas de abastecimento no periodo de 1990 a 2003 no município de São Paulo.

\section{TABELAS}

Tabela 5.1 - Média do Índice CPO-D e os Limites Inferiores (LI) e Limites Superiores (LS) para o $\mathrm{IC}_{95 \%}$, nas idades de 7 a 12 anos dos estudos epidemiológicos realizados no município de São Paulo no periodo de 1969 a 2002.

Tabela 5.2 - Média do Índice ceo-d nas idades de 5 a 10 anos dos estudos epidemiológicos realizados no município de São Paulo no período de 1983 a 2002.

Tabela 5.3 - Porcentagem de crianças de 12 anos livres de cárie dentária (CPO-D =0), Limite Inferior (LI) e Limite Superior (LS) da distribuição de freqüência do $\mathrm{IC}_{95 \%}$, município de São Paulo, no período de 1969 a 2002.

Tabela 5.4 - Média de consumo anual de ácido fluorsilícico e o IC $95 \%$, segundo meses dos anos no período de 1989 a 1993 na ETA

Guaraú, São Paulo 70

Tabela 5.5 - Estações de Tratamento de Água da Grande São Paulo, segundo vazão de água, consumo diário de ácido fluorsilícico, número de tanques de armazenagem e a capacidade de estocagem São Paulo, 2004 
Tabela 5.6 - Consumo anual de ácido fluorsilícico, consumo de água $\left(\mathrm{m}^{3}\right)$, consumo total de ácido fluorsilicico por volume água $\left(\mathrm{Kg} / 1000 \mathrm{~m}^{3}\right)$, média de consumo de ácido fluorsilícico, desvio padrão e $I_{95 \%}$, na ETA Guaraú no período de 1985 a 2003, São Paulo.

Tabela 5.7 - Custo anual de tratamento de água segundo componentes dos custos, ácido fluorsilícico, produtos químicos, recursos humanos, energia elétrica, transporte e outras despesas, e o volume total de água tratada nos anos de 1998 a 2003 na ETA Guaraú, São Paulo.

Tabela 5.8 - Custos de capital inicial de instalação, segundo componentes de custos para o sistema de tratamento de água do município de São Paulo, 2004.

Tabela 5.9 - Custos do ácido fluorsilícico utilizado para fluoretação do sistema de tratamento de água do município de São Paulo, 2004 .89

Tabela 5.10 - Custos de operacionalização do sistema, segundo os Custos de depreciação e manutenção dos equipamentos, incluindo energia elétrica e recursos humanos para fluoretação do sistema de tratamento de água do município de São Paulo, no período de 1998-2003

Tabela 5.11 - Composição dos custos de fluoretação das águas de abastecimento público no município de São Paulo, no período de 1998 a 2003

Tabela 5.12 - Custos de fluoretação das águas de abastecimento público no período de 1986 a 2003 no município de São Paulo. 99

Tabela 5.13 - Composição dos custos da fluoretação da água de abastecimento público para municípios, segundo o número de habitantes, 2004 
Tabela 5.14 - Média do índice CPO-D segundo idade e a porcentagem de redução da experiência de cárie dentária no período de 1986 a 1998 no município de São Paulo.

Tabela 5.15 - Média do índice CPO-D, incremento de cárie por idade e média nas faixas etárias de 7 a 12 anos de idade no período de 1986 e 1998 no município de São Paulo.

Tabela 5.16 - Equação da relação Benefício/Custo e seus componentes segundo sistema privado e público em real e dólar para avaliação do sistema de fluoretação das águas de abastecimento no município de São Paulo, 2004 
LISTA DE SIGLAS, SIMBOLOS, FÓRMULAS E ABREVIATURAS

\begin{tabular}{|c|c|}
\hline$A C D$ & - Atendente de Consultório Dentário \\
\hline ADA & - American Dental Association \\
\hline AFS & - Ácido Fluorsilícico \\
\hline AFS/dia & - Ácido Fluorsilícico por dia \\
\hline$B / C$ & - Beneficio por Custo \\
\hline BIRD & - Banco Mundial \\
\hline $\mathrm{C} / \mathrm{B}$ & - Custo por benefício \\
\hline $\mathrm{CC}$ & - Custo de Controle \\
\hline CCII & - Custo de Capital Inicial de Instalação \\
\hline$C D$ & - Cirurgião Dentista \\
\hline $\mathrm{CDC}$ & $\begin{array}{l}\text { - Centers for Disease Control and Prevention (Centro de } \\
\text { Controle e Prevenção de Doenças) }\end{array}$ \\
\hline ceo & $\begin{array}{l}\text { - Índice de dentes decíduos cariados, com extração indicada e } \\
\text { obturados }\end{array}$ \\
\hline CMI & - Coeficiente de Mortalidade Infantil \\
\hline $\cos$ & - Custo de Operacionalização do Sistema \\
\hline CPI-U & - All urban consumer price index \\
\hline CPO-D & - Índice de dentes permanentes cariados, perdidos e obturados \\
\hline CPO-S & $\begin{array}{l}\text { - Indice de superficies cariadas, perdidas e obturadas em } \\
\text { dentes permanentes }\end{array}$ \\
\hline CPQ & - Custo de Produto Químico \\
\hline CRO-SP & - Conselho Regional de Odontologia de São Paulo \\
\hline CORSAN & - Companhia Rio Grandense de Saneamento \\
\hline $\mathrm{Cr} \$$ & - Cruzeiro \\
\hline $\mathrm{Cz} \$$ & - Cruzado \\
\hline dens & - Densidade \\
\hline DMAE & - Departamento Municipal de Água e Esgoto de Porto Alegre \\
\hline ETA & - Estação de Tratamento de Água \\
\hline EUA & - Estados Unidos da América \\
\hline $\mathbf{F}$ & - Flúor \\
\hline
\end{tabular}




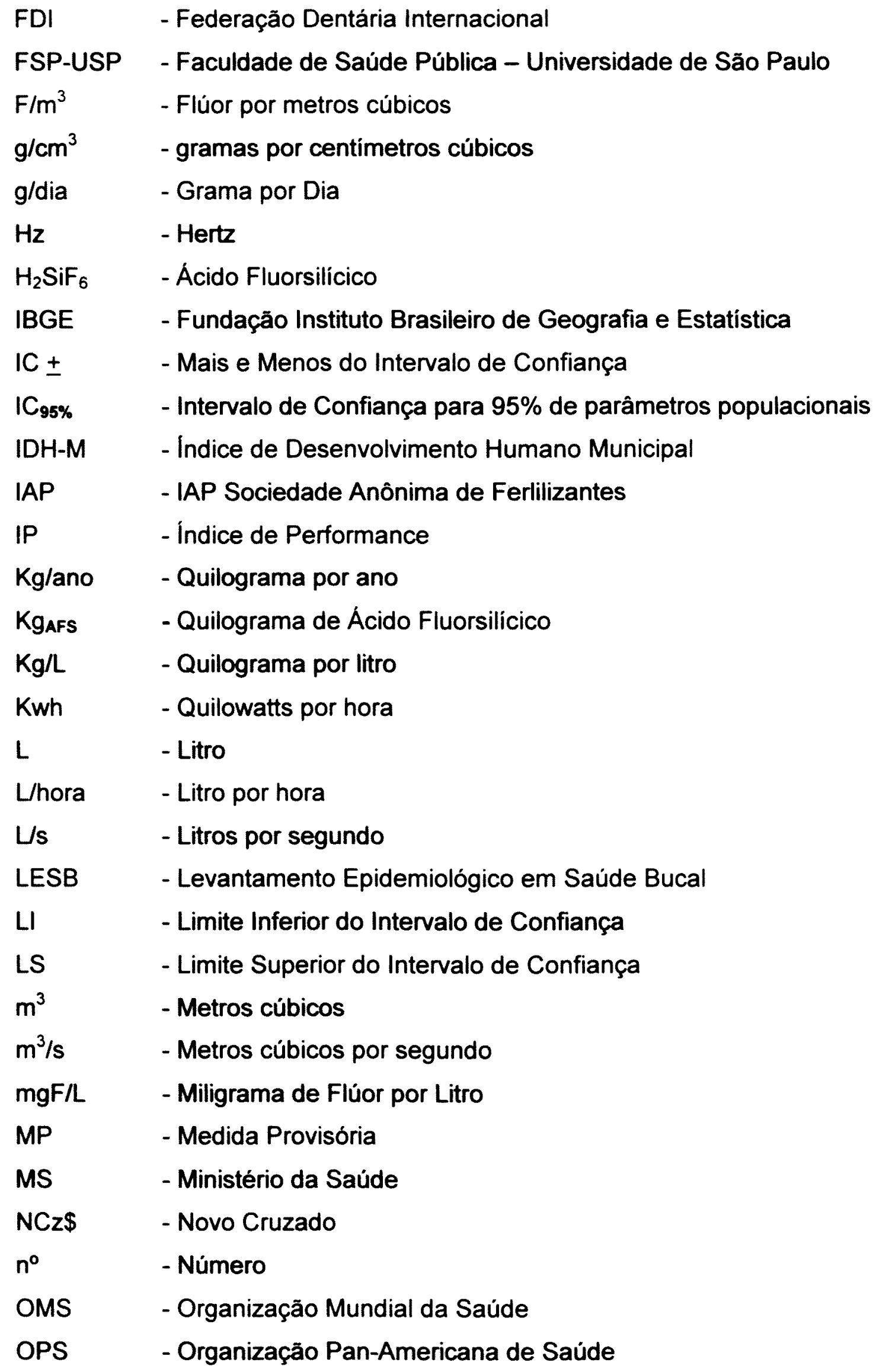




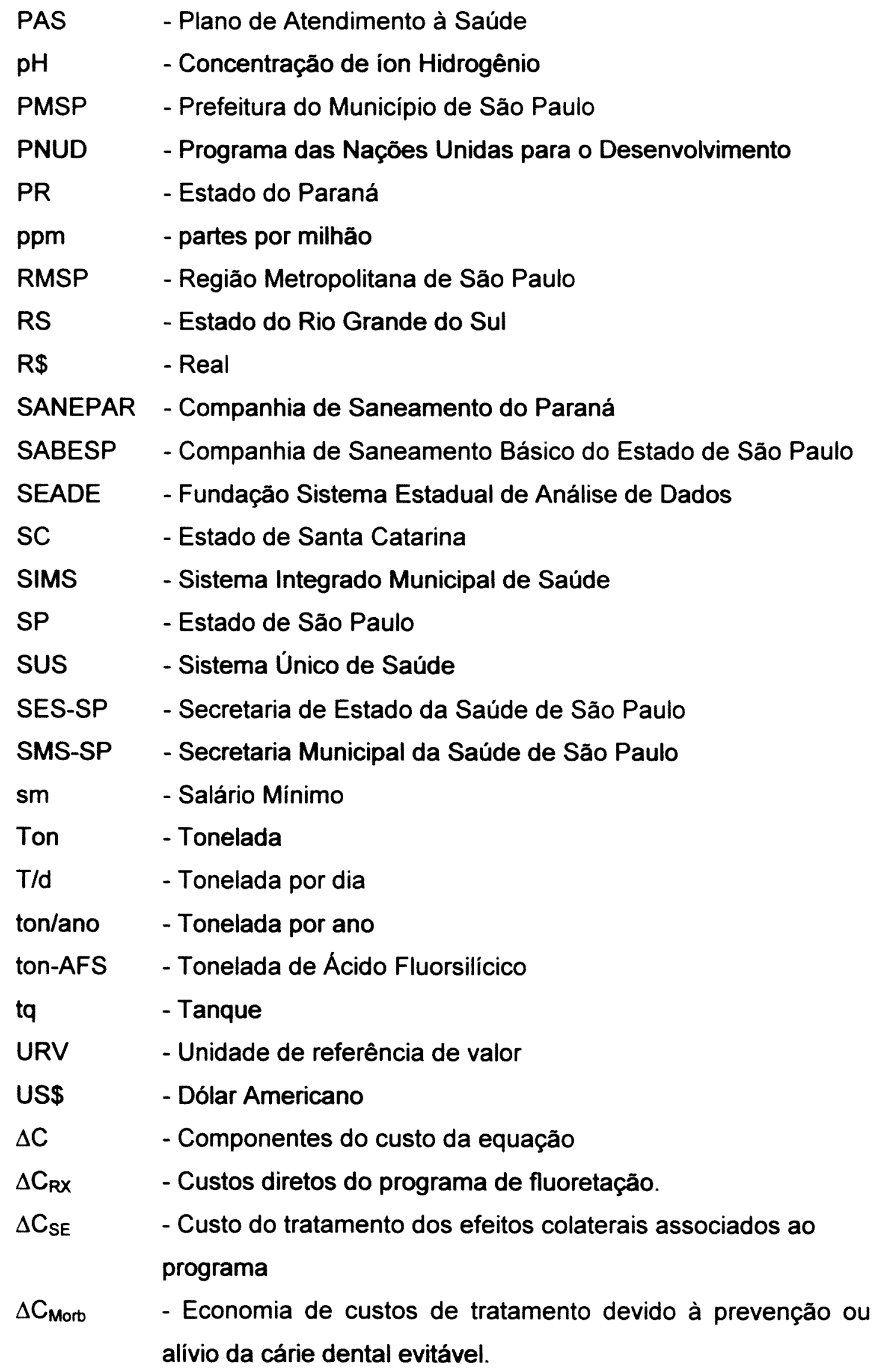


$\Delta \mathrm{C}_{\mathrm{RXLE}} \quad$ - Custos de tratamento de doenças que poderiam ter sido evitadas se o dente tivesse sido protegido pelo flúor

$\Delta \mathrm{E} \quad$ - Componentes de efetividade da equação

$\Delta Y \quad$ - Diferença na saúde bucal em locais com e sem fluoretação das águas de abastecimento

$\Delta \mathrm{Y}_{\text {Morb }} \quad$ - Ajuste na qualidade de saúde bucal devido à prevenção da morbidade associada à cárie dental não prevenida

$\triangle Y_{S E} \quad$ - Ajuste na qualidade de saúde bucal devido aos efeitos colaterais do programa de fluoretação 


\section{INTRODUÇÃO}

A fluoretação das águas de abastecimento público é uma medida "efetiva" (NEWBRUN 1996), para reduzir a prevalência de cárie em âmbito populacional, tem "baixo custo per capita" (GRIFFIN et al 2001), atingindo de forma indiscriminada e de maneira "universal" (NEWBRUN 1989), todas as pessoas abastecidas por água, além de ser "seguro" (OMS 1970), pois não causa danos à saúde quando o flúor está dentro de padrões recomendados como ótimos.

Assim, a adição do flúor na água provou ser uma medida de prevençăo da cárie dentária e, conseqüentemente, diminui as perdas dentárias na população (VIEGAS 1961). A sua não utilização, equivale a não empregar uma medida benéfica aos dentes, como demonstram pesquisas epidemiológicas realizados em vários países (AST et al 1970; HUNTER \& HENDERSON 1982; VIEGAS \& VIEGAS 1985; BATTELLINO et al 1997; FREYSLEBEN et al 2000), pois a utilização do flúor tem papel fundamental como mecanismo de diminuição da prevalência de cárie dentária.

A fluoretação das águas de abastecimento público é a medida mais ampla de promoção de saúde na área de saúde bucal, pois associa ao benefício da água tratada, o seu impacto epidemiológico na redução de prevalência de cárie dentária, que é em média de $60 \%$ (BROWN et al 1959; VIEGAS 1961; OMS 1970; RIPA 1993; SCHNAIDER FILHO et al 1992; NARVAI 1997) após 10 anos de uso contínuo. 
A fluoretação das águas de abastecimento público, embora seja tema de pesquisa em Odontologia desde a década de 40 tanto na área clínica como na área de Saúde Coletiva, ainda é um tema atual que merece pesquisa e vigilância para que se possa obter a eficiência na redução da prevalência de cárie dentária. É um método que reduz o número de dentes permanentes perdidos e o número de dentes atacados pela cárie dentária além de não depender do componente individual para sua aplicação pois, sendo o consumo de água natural, o benefício ocorre de modo involuntário.

A incorporação do flúor nas águas para o consumo humano em concentraçōes adequadas tem demonstrado eficiência, efetividade e eficácia, além de sua inocuidade para o organismo humano.

Após cerca de quatro décadas desde que se publicou o primeiro trabalho científico propondo a fluoretação das águas de abastecimento no Brasil (CHAVES et al 1953b), a medida foi finalmente implantada em São Paulo em outubro de 1985, em meio a questionamentos sobre sua segurança, eficácia, efetividade e custo-benefício (NARVAI 1997).

Desde então, pesquisas têm sido publicadas atestando a efetividade da fluoretação das águas (BROWN et al 1959; RIPA 1993) inclusive no municipio de São Paulo (NARVAl et al 2000b). Não há, até o presente, qualquer investigação cujo objetivo tenha sido analisar o custoefetividade desta medida coletiva para a prevenção da cárie dentária no municipio. $O$ objeto desta pesquisa focaliza exatamente esse aspecto, tomando como base a análise do cenário epidemiológico da cárie dentária 
entre escolares da capital e, também, problematizando aspectos relacionados com os custos da fluoretação.

Neste estudo, aborda-se o impacto epidemiológico da fluoretação das águas de abastecimento público no município de São Paulo no período de 1985 a 2003 e a mudança no perfil epidemiológico da cárie dentária, após 18 anos de implementação dessa medida, tendo como indicador de estudo a idade-índice de 12 anos e o incremento de cárie dentária em crianças de 7 a 12 anos de idade. Comparam-se os resultados de levantamentos realizados neste período com estudos anteriores, bem como identificam-se os gastos referentes aos custos de implantação e de manutenção do programa de fluoretação, estabelecendo-se a relação de custo-efetividade desta importante medida de interesse público, bem como a relação de custo-benefício da fluoretação no município de São Paulo. 


\section{REVISÃo DA LITERATURA}

\section{1 Águas de abastecimento e a fluoretação}

A água está intimamente relacionada com o desenvolvimento da vida no planeta, pois foi a partir desta que a vida originou-se e permitiu o desenvolvimento de seres unicelulares até seres vivos complexos. A manutenção da vida depende fundamentalmente da disponibilidade da água assim como o desenvolvimento de civilizações depende da utilização racional dos recursos hídricos.

Hipócrates, celebre médico que viveu há 2.500 anos, em seu artigo "Ares, águas e lugares" (apud OPS 1988), ressalta a importância da observação das doenças baseada em evidências, além das caracteristicas ambientais, da utilização da água e do comportamento das pessoas. Assim, com associação de diversos fatores, Hipócrates propõe medidas profiláticas e de cura para os enfermos:

"Quem deseja estudar corretamente a ciência da medicina deverá proceder da seguinte maneira. Primeiro deverá considerar que efeitos podem produzir cada estação do ano posto que as estações não são todas iguais. Sendo que diferem amplamente tanto em si mesma como em suas mudanças. O seguinte ponto se refere aos ventos quentes e os 
frios especialmente aos universais mas também aqueles que são peculiares em cada região em particular".

“Deverá também considerar as propriedades das águas, pois tal como estas diferem em sabor e peso também as propriedades de cada uma diferem grandemente das de quaisquer outras... Deverá considerar com o maior cuidado todas estas coisas e também aonde tem que ir os nativos para buscar água, se usam águas pantanosas e suaves, ou as que são duras e vêm de lugares altos e rochosos, ou são salobas e os aspectos (...) agora quero reafirmar que as águas, aquelas que trazem a enfermidade, e a saúde muito boa e os males e os bens que são possiveis que se originam nas águas".

Assim, Hipócrates (apud OPS 1988) ressalta a importância da água e sua relação com a manutenção da vida e da boa saúde e também como veículo de transmissão de algumas doenças. A presença do Vibrio cholerae na água de abastecimento é um fator de transmissão da cólera, assim como a presença de um componente químico na água pode causar dentes manchados ou ter, como conseqüência desejada, a diminuição de prevalência de outra enfermidade. Esta diferença entre ser causa de uma enfermidade e/ou fator de proteção de outra é, no caso do presente estudo, apenas uma questão de dosagem deste elemento quimico, o flúor.

Segundo MOORE e CORBETT (1973), a cárie acompanhou o homem desde os primórdios da civilização e, embora presente em $60 \%$ a 
$70 \%$ dos crânios, apresentava baixa freqüência e atingia individuos adultos. Segundo NARVAI (2000a), no século XIX a cárie tornou-se pandemia devido à expansão no consumo de açúcar de cana em todo o mundo ocidental. Assim, a mudança de padrōes alimentares levou a população ao convívio da dor, sofrimento e mutilação, que são conseqüências da cárie dentária.

O conhecimento de mecanismos de prevenção da cárie dentária através da utilização do flúor tem como conseqüência a mudança no quadro epidemiológico da doença. A relação do flúor com a cárie dentária, teve seu efeito comprovado a partir dos estudos iniciais de uma outra patologia, a Fluorose Dentária, doença com características endêmicas em algumas comunidades.

Segundo VIEGAS (1961), a presença de fluoretos em dentes de elefantes fossilizados foi observada pela primeira vez por Morozo (1802), e em esmalte de dentes humanos foi comprovada em 1805, por Morichini.

Em 1901 J.M. Eager médico da Marinha dos Estados Unidos, descreveu dentes manchados em habitantes de Pozzuoli, província de Nápoles na ltália e, na mesma época, esta observação foi feita pelo Prof. Stefano Chiaie, o qual atribuiu essas manchas à ingestão de água carregada de húmus vulcânico. Estes dentes foram então chamados de "Denti di Chiaie" (GANDRA 1951; BUENDIA 1996).

O cirurgião-dentista Frederick McKay observou, na cidade de Colorado Springs, a presença de dentes manchados na população desta comunidade que chamou de "esmalte mosqueado". Posteriormente, estudos 
de BLACK e MCKAY (1916) relacionaram os dentes manchados a alguma substância presente na água de consumo. McKAY (1929) relatou que as crianças que apresentavam seus dentes manchados (fluorose dentária) apresentavam acentuada diminuição de cárie dentária.

DEAN (1933) estabeleceu a relação do flúor presente nas águas de abastecimento com a ocorrência de dentes manchados (fluorose dentária). Em 1934, DEAN propôs um sistema de classificação para a fluorose dentária segundo a severidade da lesão no esmalte dentário. Segundo VIEGAS (1961), Dean e Evolve, entre 1935 e 1937, procuraram estabelecer o limite mínimo de flúor que não produzisse fluorose endêmica e ainda fosse eficiente na prevenção parcial da cárie dentária, e concluíram que o teor de flúor a ser adicionado à água de abastecimento público deveria estar em torno de $1 \mathrm{ppm}$. Com a concentração de 1ppm de fluoreto, deve-se encontrar $88 \%$ a $90 \%$ da população livre de sinais macroscópicos de fluorose dentária. Esta concentração de flúor permite a redução de dois terços, em média, dos problemas odontológicos que são representados pelo número de dentes atacados pela cárie dentária e pela extração dos primeiros molares permanentes.

\subsection{Fluoretação artificial das águas de abastecimento}

COX (1939) propôs à American Dental Association - ADA que recomendasse oficialmente a fluoretação das águas de abastecimento público. Esta recomendação ocorreria 11 anos depois, em 1950, quando já 
estavam consolidados os resultados das primeiras experiências de fluoretação controlada (ADA 1951 citado in NARVAI 2000a).

ARNOLD et al (1962) em pesquisas longitudinais realizadas no periodo de 1945 a 1954 no Estado de Michigan (EUA) nas cidades de Grand Rapids, Muskegon e Aurora e a realizada por BROWN et al (1959) no mesmo período no Canadá, nas cidades de Brandford, Samia e Strantford, compararam dados epidemiológicos relacionados à prevalência de cárie dentária em crianças numa cidade com flúor natural, em outra cidade onde o flúor foi colocado artificialmente e em uma cidade controle sem flúor em suas águas de abastecimento pủblico. Estes estudos provaram a associação do flúor com a prevenção da cárie dentária e demonstraram não haver diferença quanto ao efeito de redução de prevalência de cárie entre o flúor encontrado em mananciais (natural) e o flúor adicionado de maneira artificial na rede de água de abastecimento público.

Segundo BAKER (1948) citado por MAIER (1970), nos primórdios da humanidade a água era ingerida na forma que era encontrada na natureza; podendo ser pura e abundante, turva e escassa ou de baixa qualidade e potabilidade. As primeiras normas de qualidade estabelecidas pelo homem a respeito da água fixaram que esta deveria ser clara, insípida e inodora.

Segundo MAIER (1970), a adição de flúor na água de abastecimento foi uma "medida revolucionária", pois no tratamento de água sempre se procurou eliminar matérias nocivas da água $\mathrm{e}$ introduzir 
determinadas características a fim de alcançar os efeitos desejados. A adição de compostos fluorados não tinha nenhum benefício para o tratamento da água ou qualidade desta, mas um benefício para prevenção de cárie nas populações. À medida que foram sendo aceitos os aditivos à água tais como os compostos de alumínio, fósforo, cal e cloro, que contribuíram para a melhoria dos sistemas, foi também aceita a adição de fluoretos.

Nos anos 60, a adição de flúor na água de abastecimento já estava incorporada em muitos sistemas e em muitos paises, e era procedimento normal e habitual como parte do tratamento da água (MAIER 1965).

Desde 1958, a Organização Pan-americana da Saúde (OPS, 1975, 1987), e a Organização Mundial da Saúde (OMS, 1970, 1986), recomendam e estimulam que os paises implementem a fluoretação das águas de abastecimento público para atender a população, visto ser essa medida a mais eficaz, segura e econômica para o controle da cárie dentária.

O Centro de Controle e Prevenção de Doenças (CDC) dos Estados Unidos, ao fazer um balanço das conquistas no setor de saúde pública no século $X X$, identificou a fluoretação das águas de abastecimento público entre as dez mais importantes ações da saúde pública (CDC 1999).

O Department of Health and Human Services dos Estados Unidos da América, estabelece como meta para o ano de 2010 que $75 \%$ da população seja beneficiada pela fluoretação das águas de abastecimento 
público (CDC 2002). No ano de 2000, aproximadamente 162 milhões de pessoas $(65,8 \%)$ eram beneficiados pela fluoretação das águas naquele pais (CDC 2002).

\subsection{Fluoretação no Brasil}

O primeiro município no Brasil a fluoretar suas águas de abastecimento público foi Baixo Guandú, no Espirito Santo, em 31 de outubro de 1953, realizado pelo Serviço Especial de Saúde Pública (SESP) (VIEGAS 1961). Esta é uma data histórica pois, a partir dessa iniciativa pioneira, muitos estados e municipios adotaram a medida de prevenção como eixo de suas estratégias para enfrentar o problema da cárie dentária. A primeira capital a fluoretar suas águas foi Curitiba, em 1959 (NARVAI 2000a)

No Estado de São Paulo, a primeira cidade a fluoretar artificialmente suas águas para consumo humano foi Marilia, em 12 de dezembro de 1956 (BUENDIA 1983). No Estado de São Paulo, a Lei Estadual $n^{\circ} 4.637$, de 18 de abril de 1958 , regulamentou a fluoretação no Estado (SÃO PAULO 1958).

A cidade de São Paulo teve suas águas de abastecimento público fluoretadas em 31 de outubro de 1985 (NARVAI 1997). A empresa responsável por esta fluoretação foi a Companhia de Saneamento Básico do Estado de São Paulo (SABESP). 
A Lei Federal $n^{\circ} 6.050$ de 24/05/1974 tornou obrigatória a fluoretação das águas de abastecimento público em todo o território brasileiro "onde houver estação de tratamento de água". O Decreto Federal $n^{\circ} 76.872$ de 24/12/1974 regulamentou a lei e a portaria $n^{\circ} 635$ de 26/12/1975 e estabeleceu os padrões para operacionalização da medida (BRASIL 1976, NARVAI 2001).

Segundo a Lei Federal $n^{\circ} 6.050$ de 24/05/1974, há uma previsão de financiamento destinado à implantação do sistema de fluoretação. Como consta no Art. $2^{\circ}$ "A captação de recursos para a aquisição do equipamento e dos produtos necessários à fluoretação poderá ser feita mediante financiamento concedido por estabelecimento de crédito oficial" e no Art. $7^{\circ}$ do Decreto Federal 76.872 de 24/12/1974 destaca que "Os órgão oficiais de crédito concederão facilidades para a obtenção de financiamento destinado à instalação dos sistemas de fluoretação da água" (BRASIL. 1976).

O Decreto Federal 76.872 de 24/12/1974 destaque em seu Art. $5^{\circ}$, diz que é responsabilidade do Ministério da Saúde e das Secretarias de Saúde a fiscalização e o cumprimento das normas estabelecidas no Decreto e no Art. $6^{\circ}$ que "Os dirigentes dos órgãos responsáveis pelos sistemas de abastecimento de água ficarão sujeitos às sanções administrativas cabiveis, de acordo com o regime jurídico a que estejam submetidos, pelo não cumprimento deste decreto e de suas normas complementares." (BRASIL 1976). 
Segundo NARVAI (2000a), a fluoretação das águas "apresenta um enorme potencial de universalização e, ademais, contribui para que as pessoas tenham acesso à água tratada, talvez a mais importante ação de saúde pública". Ainda segundo NARVAI (2000a), "os principais interessados na fluoretação das águas de abastecimento público são os segmentos sociais de baixa renda, pois este grupo social é desfavorecido e desprovido de outros fatores de proteção ou com acesso marcadamente restrito". Assim, "os que mais precisam não apenas obtêm o benefício mas, neles, este fator de proteção tem maior força".

Garantir a fluoretação das águas, além do beneficio já mencionado e de seu baixo custo, é uma medida "democrática", que tem uma abrangência de $100 \%$ da população servida pela rede de abastecimento. É, conforme mencionado uma medida amparada legalmente no Brasil em âmbito nacional, desde 1974.

Água fluoretada é um direito de cidadania, mas é necessário também garantir a toda população o direito de acesso à água potável, um determinante para melhoria das condições de vida, de dignidade e de saúde geral das comunidades. Acesso à água potável é um direto do cidadão e um dever do Estado, com amparo legal na Constituição Brasileira.

Portanto, faz-se necessário um controle efetivo dos niveis de flúor das águas servidas pelas empresas distribuidoras. A vigilância das águas e seus teores de flúor (heterocontrole), deve ser parte da rotina da 
Vigilância Sanitária dos municipios. Segundo NARVAI, (1997) "não fluoretar a água ou interromper a fluoretação sem razão para isso, quando esta medida é recomendada, constitui ato juridicamente ilegal, cientificamente insustentável e socialmente injusto".

Segundos dados do Ministério da Saúde (BRASIL 2003), em 1996 , apenas $60,8 \%$ da população tinham acesso à água tratada e $43,3 \%$ da população recebiam flúor na água de abastecimento. Em 1996 onze capitais não haviam ainda implantado o sistema de abastecimento com flúor.

Segundo GANDRA (1951), no Estado de São Paulo em 1950, foram coletadas informações sobre o teor de flúor na água de 334 cidades e em 12 reservatórios da capital. Segundo a pesquisa, $82,2 \%$ da população não tinham acesso à água tratada; o valor médio da concentração de flúor nos mananciais pesquisados era de, em média, 0,0968 ppm de flúor (IC $\pm 0,0062)$. Segundo esta pesquisa, a concentração de flúor natural nos reservatórios era muito baixa para ter benefício na redução da prevalência de cárie dentária na população do estado.

CALVO (1996) fez um extenso levantamento sobre a situação das águas no Estado de São Paulo. Considerando os 625 municípios, a rede de abastecimento atingia $86 \%$ da população total e $93 \%$ da população urbanizada, sendo que 431 municípios apresentam flúor em suas águas de abastecimento. Isto representava $91,1 \%$ da população total e $91,8 \%$ da população com água de abastecimento. Segundo a pesquisa, a Sabesp fornecia água para 330 municipios $(58,9 \%$ da população total), sendo que 
97,8\% dos municípios abastecidos pela Sabesp têm sistemas de fluoretação de água. Em relação aos municipios que eram abastecidos pelas prefeituras ou companhias autônomas, 64,7 \% deles não apresentavam suas águas fluoretadas.

Segundo relatório do Conselho Regional de Odontologia de São Paulo (CRO-SP 2001), ocorreu um aumento na população servida por águas de abastecimento com flúor (94,9\%). A Sabesp é responsável pelo abastecimento de 369 municípios sendo que todos têm suas águas fluoretadas. Já as empresas autônomas são responsáveis por 276 municipios. Destes, $46,4 \%$ não são fluoretados, o que representa $5,06 \%$ da população do Estado de São Paulo não beneficiada pelo flúor em suas águas de abastecimento.

Garantir a fluoretação das águas representa, além da certeza da redução de dentes acometidos pela cárie e perda precoce destes, uma luta também pela melhoria da qualidade de vida, pois para que ocorra a fluoretação, é necessário que as águas passem pelo processo de tratamento e de cloração, propiciando assim melhores condições de saúde da população e, conseqüentemente, da qualidade de vida. Embora o custo per capita seja relativamente baixo, segundo CHAVES (1953a), uma das maiores dificuldades na implantação da fluoretação nos sistemas de abastecimento público de água é o custo inicial na compra de equipamentos, devido aos poucos recursos municipais disponiveis. Esta justificativa 
também aparece na pesquisa sobre a "Situação da fluoretação das águas de abastecimento público no Estado de São Paulo" (CALVO 1996).

Segundo PINTO (1993), "fatores econômicos sempre são responsáveis por uma interrupção no processo, em parte porque o flúor não é considerado essencial para a potabilidade da água". Nos Estados Unidos, a fluoretação das águas teve considerável avanço em sua implementação nos periodos em que houve o custeio de implantação pelo setor público (PINTO 2000).

\subsection{Custos da fluoretação}

A Associação Americana de Saúde Publica, citada por CHAVES (1986), considera que avaliação "é o processo pelo qual se determina o valor ou o nivel de sucesso na consecução de um objetivo predeterminado, incluindo quatro passos: a formulação de objetivos, a identificação de critérios de medida, a determinação e explicação do grau de sucesso e a recomendação para reajuste das atividades do programa".

A análise de custos referente à programas ou ações de saúde deverá incluir tanto os custos de natureza fixa como os custos variáveis, os encargos de capital e os encargos individuais e sociais. Esta análise deverá conter os custos diretos e indiretos. Assim, com relação à avaliação econômica de serviços de saúde, UGÁ (1995) afirma que "o custo de cada linha de ação deve ser medido pelo sacrifício do uso alternativo mais próximo dos recursos reunidos". Para melhor analisar a eficiência do método aplicado, deve-se compreender suas relações de "custo-eficácia", 
"custo- efetividade", "custo-eficiência" e "custo-beneficio", e esta avaliação se propicia em diversos niveis, desde o ideal até o real.

Segundo PEREIRA (2000), eficácia é a investigação do impacto das tecnologias em condições ideais de observação, testando em laboratório, reproduzindo condições perfeitas, e controlando as variáveis intervenientes no processo. Efetividade é a utilização de tecnologias no plano real e a avaliação de seu impacto em condições normais com influências de inúmeras variáveis individuais e sociais em grupos populacionais e seu meio ambiente ou seja, no "mundo real". A eficiência leva em conta, além do impacto de determinado programa ou ação, os recursos financeiros, os recursos humanos e os recursos materiais empregados nas tecnologias para o desenvolvimento do programa ou seja, a "parte econômica da avaliação".

Segundo UGÁ (1995), a análise de custo-beneficio "destina-se a avaliar a viabilidade econômica de projetos sociais, podendo-se aplicá-lo a um determinado programa ou a vários, para compará-los em termos de sua rentabilidade social". Esta rentabilidade social pode ter influência direta na diminuição de gastos com $\circ$ tratamento e a recuperação de doentes acometidos por agravos evitáveis ou uma ação indireta devido a melhoria da qualidade de vida e o aumento da esperança de vida da comunidade, revertendo o quadro epidemiológico na medida em que diminuem a morbidade e a mortalidade. 
WHITE et al (1989) propõem que a determinação da efetividade da fluoretação das águas de abastecimento público na prevenção da cárie dentária em uma comunidade é influenciada por, pelo menos, 3 variáveis: 0 indice de cárie dentária inicial (antes da fluoretação) e as mudanças nos padrões da doença no tempo, levando em consideração o decréscimo natural dos padrōes da doença; a mobilidade da população nesta comunidade e, finalmente, a proporção de pessoas com maior risco de cárie dentária.

WHITE et al (1989) identificam dez variáveis importantes para a identificação de custos diretos da fluoretação que são: custo político, custo trabalhista, custo quimico, custo de equipamentos, custo operacional, custo de equipamento para monitoramento do flúor, quantidade de flúor natural, nível ideal de flúor, número de pontos de injeção e custo de consultoria técnica.

1. Custo Político - para iniciar a fluoretação em uma comunidade nos Estados Unidos da América é necessária a realização de um referendo popular. Assim, são realizadas campanhas contra e a favor da fluoretação e, no final, a fluoretação é submetida a um plebiscito para sua implantação ou não na comunidade. Isto representa um custo gerado no processo de decisão de aplicar a medida.

2. Custo trabalhista - número de empregados necessários para a manutenção do sistema e seus respectivos salários, ou seja, para 
ajustar os niveis de flúor na água, para a manutenção do equipamento e para monitorar os niveis de flúor.

Segundo NIESSEN e DOUGLASS (1984), o custo trabalhista por ponto de injeção de flúor é de US\$1.000,00 ou seja, de US\$2,00/dia. GRIFFIN et al (2001), avaliaram que os custos trabalhistas variam de US $\$ 7,00$ a US $\$ 9,00$ por hora de trabalho.

3. Custo químico - envolve a escolha do produto químico (Fluoreto de Sódio, Ácido Fluorsilícico ou Fluorsilicato de Sódio), o custo do produto e a quantidade necessária a cada ano.

Segundo NIESSEN e DOUGLASS (1984), há um custo de US\$ 240,00 por ponto de injeção ou US\$ 0,66 por dia quando utiliza-se ácido fluorsilícico. Segundo NELSON e SWINT (1976), em Houston (EUA), o custo com o ácido fluorsilícico foi de US\$1.103.100,00 durante 20 anos sem ajuste, ou US\$151,11 por dia. WRIGHT et al (2001), descrevem o custo do ácido fluorsilícico em US $\$ 200,00$ por tonelada ou US $\$ 0,18$ por pessoa/ano. Para GRIFFIN et al (2001), o custo médio do ácido fluorsilicico é de US\$ 0,19 por pessoa variando segundo o volume adquirido. Assim, para o volume de um garrafão que corresponde a 15 galōes $(56,775$ litros) o custo é de US\$ 0,25; para o volume de um tonel que corresponde a 55 galões ( 285,175 litros) o custo é de US\$ 0,18 centavos; e para volumes maiores como tanques de armazenamento o custo é reduzido para US $\$ 0,11$ por pessoa beneficiada pela fluoretação. Para DOWELL (1976), o custo do 
produto sofre variação dependendo da distância entre a origem do suprimento do produto quimico e o ponto de fluoretação na comunidade.

4. Custo dos equipamentos - devem incluir: o custo de aquisição, o custo de manutenção esperado, o tempo de durabilidade do equipamento (devido à necessidade de substituição pelo tempo de uso ou por se tornar obsoleto) computando, assim, o custo da sua substituição.

Segundo NIESSEN e DOUGLASS (1984), este custo é de US\$ $6.000,00$ por ponto de injeção. Segundo MANAU et al (1987), temos US $\$ 58.333,00$ incluindo a instalação. Para HOROWITZ e HEIFETZ (1979), US\$ 0,05 por pessoa /ano.

Segundo WHITE et al (1989), o custo do capital da fluoretação tem um aumento anual na mesma proporção do aumento da população no mesmo periodo. Isto contradiz ao fato reconhecido de que há economia de escala de custo na fluoretação. Nos primeiros 10 anos, há uma redução considerável na prevalência da cárie dentária em média de $60 \%$ e, após este periodo, a redução continua ocorrendo mas em menor proporção. O custo de oportunidade de investimento do capital citado por WHITE et al corresponde ao financiamento público, que é um grande estímulo para a implantação da fluoretação (CALVO 1996; PINTO 2000). O custo de depreciação ocorre na medida em que o capital (equipamento) perde seu valor ao longo do tempo e não tem valor de revenda segundo RINGELBERG et al (1992), GARCIA (1989) e WRIGHT (2001). 
Para levar em conta os custos de capital inicial e o de depreciação, é necesário haver uma amortização bem como uma atualização pelo periodo esperado de vida útil do equipamento. Este período varia entre 10 anos segundo NIESSEN e DOUGLASS (1984), 15 anos segundo RINGELBERG et al (1992), GARCIA (1989) e WRIGHT (2001), 20 anos segundo NELSON e SWINT (1976) e MANAU et al (1987), ou 25 anos segundo CARR et al (1980).

5. Custo operacional - o custo de operacionalização da fluoretação deve ser calculado anualmente incluindo os custos de eletricidade, aluguel, seguro e custos de espaço compartilhado. "Apesar de geralmente ser difícil o cálculo e inclusão, não é apropriado excluir estes custos e estes podem ter o valor estimado" (WHITE et al 1989), podendo ser calculados a partir dos custos da estação de tratamento de água.

6. Custo do equipamento de teste para a medição do nivel de flúor ideal (monitoramento do flúor na água) - neste item de custo, inclui-se o tempo esperado de vida do equipamento e o custo de reposição do equipamento.

7. Quantidade de flúor natural - ou seja, o teor de flúor residual na água deve ser levado em conta para o cálculo de custos pois, assim contabiliza-se apenas a quantidade necessária do componente químico utilizado para atingir o nivel ideal. 
Para NIESSEN e DOUGLASS (1984) a quantidade de flúor encontrada nas águas antes do tratamento era de $0,1 \mathrm{ppm}$ de flúor natural. Para NELSON e SWINT (1976), em Houston (Texas) a quantidade de flúor natural era muito pequena para poder ser registrada. GANDRA (1951), encontrou em 12 estações de tratamento, no município de São Paulo, o correspondente a 0,1 ppm de flúor de flúor natural.

8. Nivel ideal de flúor - necessário na comunidade para atingir o maior benefício e menor risco.

NIESSEN e DOUGLASS (1984) sugerem a concentração de 1,0 ppm de flúor ao analisarem uma comunidade hipotética. RINGELBERG et al (1992) indicam 0,8 ppm de flúor para o estado da Florida (EUA). Para o Brasil sugere-se o nivel ideal de 0,7 ppm de flúor (BRASIL 1974; CALVO 1996; NARVAI 2000c).

9. Número de pontos de injeção - necessários para a fluoretação, pois há um incremento de custo devido ao aumento do número de equipamentos dependendo do número de pontos de injeção.

WRIGHT et al (2001) analisando comunidades de 1.000 habitantes, dizem que há um aumento de custo se houver de 1 a 5 pontos de injeção. Já para comunidades acima de 10.000 habitantes, não há diferença no custo com relação ao número de pontos de injeção.

10. Custo de consultoria técnica - é importante separar o custo de instalação e honorários de consultoria ou engenharia do cálculo de 
custo total pois estes valores não serão amortizados durante a vida útil do equipamento.

Segundo NIESSEN e DOUGLASS (1984) as análises de custobenefício e custo-efetividade são instrumentos analíticos que podem ser usados para avaliar as decisões de gastos públicos. Essas técnicas podem auxiliar a tomada de decisão na alocação de recursos escassos.

$\mathrm{Na}$ análise de custo-benefício é de fundamental importância, para NIESSEN e DOUGLASS (1984), elencar todos os custos tangíveis e intangiveis e que estes sejam enumerados e convertidos para um denominador comum, em geral "dólar" (referência monetária). O objetivo é maximizar o valor atual de todos os benefícios subtraindo o valor de todos os custos sujeitos a restrições especificas. Segundo estes autores, duas características da relação custo-benefício devem ser consideradas, a "largura do espaço" que é a abrangência do programa e o "comprimento do horizonte de tempo" que é o periodo no qual o programa está implantado ou foi avaliado.

DAVIES (1973) apresenta, uma fórmula para análise de custobenefício numa série de trabalhos onde a equação relaciona, no numerador, todos os custos de implantação do programa preventivo e, no denominador, as economias de tratamento ocorridas devido à prevenção das doenças:

$$
\text { Razão C/B = custo de implantação do programa preventivo }
$$


Para NIESSEN e DOUGLASS (1984), na equação de custobenefício, os benefícios tangiveis na odontologia são os relativos à economia de tratamento devido à prevenção da doença e são valorados ao preço de mercado para o tratamento de uma lesão de cárie. Já os custos indiretos ou intangiveis são excluídos da análise como vemos na equação de DAVIES (1973), e, por esta razão, os custos do programa são subestimados.

A proposta de DAVIES deve ser compreendida como um esforço teórico para produzir um indicador quantitativo de avaliação do custo-beneficio com a finalidade de tornar operacional o procedimento avaliativo. De outro modo, como quantificar e, portanto, enquadrar em fórmulas matemáticas, variáveis como "dor evitada" ou "sofrimento psíquico" decorrente de cárie ou perda dentária? Mas ao obter valores e analisá-los há que considerar sempre a subestimação desses aspectos, paradoxalmente talvez os mais significativos. Assim, tais reduções precisam ser compreendidas e seu significado devidamente considerado.

Nas análises realizadas para o cálculo do custo-benefício de programas de fluoretação de águas de abastecimento, o dimensionamento do tempo é fundamental, pois os benefícios do flúor ocorrem a longo prazo.

Propomos uma inversão na fórmula de DAVES pois, em vez de trabalharmos custo/beneficio, trabalharemos benefício/custo onde, na fórmula, o benefício é o numerador e o custo o denominador, para assim obtermos um produto, cujo resultado seja um número inteiro, facilitando a 
visualização, a mensuração, a análise e a comparação dos resultados. Se o produto for igual a 1, os beneficios têm os mesmos gastos que os custos, e se o produto for maior que 1 , conseqüentemente os beneficios são maiores que os custos empregados no programa. Se, ao contrário, o produto for menor que 1 , o programa não é viável economicamente, sendo necessário, então, levarem em conta na avaliação, outros aspectos, como o interesse social, político, cultural, dentre outros.

Enquanto a análise de custo-beneficio é usada para tomar decisões em diversas áreas e é, teoricamente a ideal, pois enquanto esta dimensiona os beneficios em valores monetários, a relação de custoefetividade é segundo NIESSEN e DOUGLASS (1984), utilizada para comparar meios alternativos para atingir os resultados esperados ou ainda, quando medir os beneficios em termos numéricos se torna mais difícil.

Sendo assim, em programas preventivos de saúde bucal, a análise do custo-efetividade é usada para determinar o custo para salvar um dente cariado, perdido ou obturado (indice CPO-D ou superficies do índice CPO-S) (HOROWITZ e HEIFETZ 1979; McCOMBIE 1979). A técnica consiste em dividir diferenças de custos de um programa pelo número de superfícies prevenidas pela cárie (não atacadas por cárie) usando uma estimativa de máximo beneficio para cada ano. Como os programas não atingem sua redução de cárie nos primeiros anos de implantação este enfoque, segundo NIESSEN e DOUGLASS (1984), superestima a efetividade nos anos que antecedem a redução máxima. 
WHITE et al (1989), analisaram a viabilidade do desenvolvimento de um programa a partir da diferença entre custo e benefício. Um programa viável apresentaria uma diferença positiva (maior que zero) entre seus benefícios e custos enquanto um programa inviável apresentaria uma relação contrária.

Ainda segundo WHITE et al (1989), para a análise da relação custo-efetividade devem ser levadas em conta algumas medidas: o aumento da permanência do elemento dental na cavidade bucal, o caso de doenças prevenidas ou identificadas, a alteração na taxa de prevalência ou incidência da doença e a melhora na qualidade de vida.

O modelo de avaliação de efetividade proposto por WEINSTEIN e STASON (1977), citado por WHITE et al (1989), apresentado no quadro 1 , coloca os custos no numerador e subtrai destes os custos econômicos relacionados aos problemas evitados pela medida. No denominador encontra-se o efeito do programa (ajustado pela doença que 0 programa não preveniu e seus efeitos colaterais). Nesta equação, a economia de tratamento é um ganho e não um efeito, por isto está no numerador e não no denominador. 
Quadro - 1. Componentes da equação de custo-efetividade proposto por WEINSTEIN E STASON (1977).

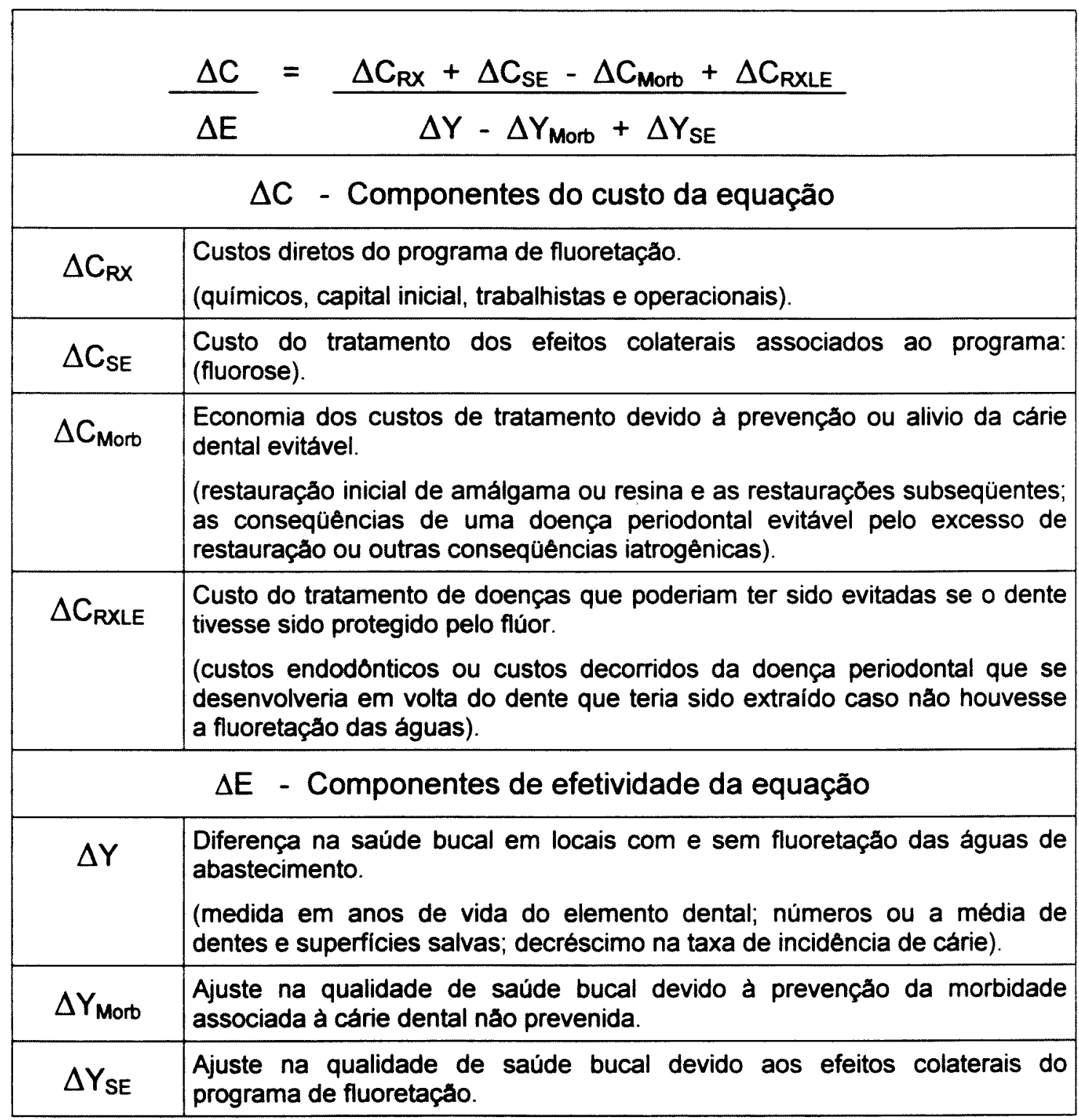

ATTWOOD e BLINKHORN (1989) realizaram um estudo de análise de custo da necessidade de tratamento em escolares de 5, 10 e 15 anos de idade comparando os dados do índice CPO-D de duas cidades (Stranraer e Annan, Escócia), respectivamente com e sem flúor, em suas águas de abastecimento público. Como resultado, observaram uma economia de $50 \%$ em média de lesões que necessitavam restauração e uma 
redução de $87 \%$ no número de dentes que necessitavam extração dentária na cidade onde havia flúor na água de abastecimento.

AST et al (1970) compararam os fatores de custos em um periodo de 6 anos em crianças residentes em Newburgh (New York), cidade fluoretada e Kingston (New York), cidade sem flúor. As crianças que ingeriram água fluoretada durante a infância necessitavam um menor tempo gasto em tratamento odontológico (duas vezes menor) que nas cidades sem flúor enquanto, na cidade sem flúor o custo de tratamento foi mais elevado bem como foi maior o custo de manutenção do tratamento devido ao incremento de cárie. Estipulando que o valor de uma restauração por superficie é de US $\$ 5,00$ e de US\$ 6,00 para uma extração, o custo inicial de tratamento é de US $\$ 13,86$ e o custo de manutenção é de US $\$ 5,18$ em Newburgh. Em Kingston, os valores são de US\$ 33,73 e US\$11,23 para tratamento inicial e de manutenção, respectivamente.

WRIGHT et al (2001) realizaram uma análise do custo-efetividade da fluoretação das águas na Nova Zelândia, tentando estabelecer uma relação entre o tamanho de uma população e o custo de implantação do sistema de fluoretação. Duas outras variáveis foram levadas em consideração: o número de pontos de abastecimento e a composição sócio-demográfica da população. Concluiram que uma população com menor condição sócio-econômica tem maior benefício da fluoretação das águas como também a população de crianças, jovens e adolescentes. Os autores concluiram também que, em populações com menos de mil 
habitantes, o custo da implantação do sistema seria muito alto, inviabilizando o método.

BIRCH (1990) relacionou o custo-efetividade do programa de fluoretação com o tamanho da população e o nivel de cárie pré-existente em três comunidades de diferentes populações $(60.000,120.000$ e 600.000 habitantes). Concluiram que há diferença de custo com relação a prevalência de carie pré-existente mesmo que as comunidades tenham tamanhos distintos.

GARCIA (1989) analisou os componentes dos custos de programas de prevenção. Custos como instalação do projeto, ampliação de construções e honorários de consultorias (gastos únicos), foram acrescidos aos custos do capital e amortizados por um período de 15 anos utilizando taxas de reajuste de $2 \%$ e $4 \%$, além de terem sido ajustados pela inflação desde 0 ano de aquisição. O fator de ajuste utilizado foi o CPI-U (all urban consumer price index). Os custos de capital apresentados foram acrescidos aos custos operacionais para obter o custo direto total por ano.

RINGELBERG et al (1992) no quadro 2 analisaram o custo da fluoretaçăo das águas em 44 comunidades da Florida (EUA) e, para tal, utilizaram a seguinte equação de custos: \{custo total / per capita\}, onde os custos totais são compostos pelos custos operacionais, e os custos de oportunidade acrescidos ao capital de depreciação. O custo total médio por ano habitante, após ajuste de $2 \%$, foi de US\$ 0,41 por pessoa/ano, e para ajuste de $4 \%$, foi de US $\$ 0,45$ por pessoa ano. O tamanho da população é 
um fator importante na composição do custo final. Assim, para comunidades de até 10.000 pessoas o custo por habitante/ano é de US\$ 2,12; para comunidades com população entre 10.000 e 50.000 habitantes o custo é de US $\$ 0,68$; e, para comunidades com mais de 50.000 habitantes, o custo médio por pessoa/ano é de US\$ 0,31 para uma taxa de ajuste de $4 \%$. Os custos médios anuais por sistema por pessoa foram de US\$1,14 e US\$1,25 para $2 \%$ e $4 \%$ de reajuste, respectivamente. 
Quadro - 2. Componentes e resultados da equação de cálculo de custos proposto por RINGELBERG et al (1992).

\begin{tabular}{|c|c|c|c|c|}
\hline \multirow{10}{*}{$\begin{array}{l}\text { Custos } \\
\text { totais }\end{array}$} & \multirow{5}{*}{$\begin{array}{c}\text { Custos } \\
\text { operacionais }\end{array}$} & \multirow{3}{*}{$\begin{array}{l}\text { Custo químico } \\
\text { Acido fluorsilícico } \\
\text { (por pessoa) } \\
\text { US\$ } 0,19\end{array}$} & $\begin{array}{c}1 \text { - Garrafão } \\
15 \text { galöes }\end{array}$ & US $\$ 0,25$ \\
\hline & & & $\begin{array}{c}\text { Tonéis } \\
55 \text { galöes }\end{array}$ & US\$0,18 \\
\hline & & & $\begin{array}{c}\text { Tanques de } \\
\text { armazenagem }\end{array}$ & US\$0,11 \\
\hline & & Custo trabalhista & $\begin{array}{l}\text { de US } \$ 7,00 \text { a } \\
\text { US } \$ 9,00 / \text { hora }\end{array}$ & \\
\hline & & $\begin{array}{c}\text { Custo de } \\
\text { operacionalização }\end{array}$ & $\begin{array}{l}\text { US } \$ 0,30 / \\
\text { pessoa }\end{array}$ & \\
\hline & \multirow[t]{3}{*}{$\begin{array}{l}\text { Custos de } \\
\text { oportunidade } \\
\text { de capital }\end{array}$} & \multirow{3}{*}{$\begin{array}{c}\text { Juros de } 2 \% \text { e } 4 \% \\
\text { sobre o } \\
\text { investimento } \\
\text { fixo inicial } \\
\text { Dólar de } 1988 \\
\text { usando o IPD - } \\
\text { (implicit price } \\
\text { deflator) }\end{array}$} & \multirow[t]{2}{*}{$\begin{array}{l}\text { Custo inicial do } \\
\text { equipamento }\end{array}$} & \multirow{3}{*}{$\begin{array}{l}\text { Custo por ponto } \\
\text { de injeção: } \\
1 \text { ponto } \\
\text { US } \$ 7.376,00 \text { - } \\
\text { US } \$ 92.061,00 \\
2 \text { a } 3 \text { pontos } \\
\text { US } \$ 6.974,00 \text { - } \\
\text { US } \$ 59.009,00 \\
\\
4 \text { pontos ou } \\
\text { mais } \\
\text { US } \$ 6.974,00- \\
\text { US } \$ 17.486,00\end{array}$} \\
\hline & & & & \\
\hline & & & $\begin{array}{c}\text { Custo de } \\
\text { instalação } \\
\text { (por pessoa) }\end{array}$ & \\
\hline & \multirow{2}{*}{$\begin{array}{c}\text { Capital de } \\
\text { depreciaçăo }\end{array}$} & $\begin{array}{l}15 \text { anos de vida útil } \\
\text { do equipamento } \\
\text { sem valor para } \\
\text { revenda }\end{array}$ & \multirow{2}{*}{$\begin{array}{c}2 \% \\
\text { US\$ } 0,09 \\
4 \% \\
\text { US\$ } 0,40\end{array}$} & \\
\hline & & $\begin{array}{l}\text { Fundo de caixa } \\
\text { para depreciação } \\
\text { (taxa de } 2 \% \text { e } 4 \% \text { ) }\end{array}$ & & \\
\hline
\end{tabular}


GRIFFIN et al (2001) analisaram a economia de custo anual comparando comunidades com e sem flúor na água de abastecimento. Os resultados mostram uma economia em tratamento dentário por pessoa / ano de US $\$ 15,95$ para comunidades pequenas e US $\$ 18,62$ para grandes comunidades. "Baseando-se nas informações disponiveis sobre efetividade, custos de fluoretação da água, incremento de cárie dentária, e custo de durabilidade das restaurações dentárias, a fluoretação das águas de abastecimento público permite uma economia de custos significativa". Para comunidades muito pequenas a fluoretação das águas não seria um método econômico segundo os resultados de GRIFFIN et al (2001), no contexto em que seu estudo foi desenvolvido.

GRIFFIN et al (2001) propõem a fórmula da evolução econômica onde se calcula o custo por pessoa, após um ano de exposição à água fluoretada baseando-se na equação de HADDIX (1996) - quadro 3 , onde o custo líquido é o resultado do custo de fluoretação, subtraindo o custo de prevenção da doença, somado às perdas de produtividade. Sendo assim, se o custo final é negativo significa que a fluoretação das águas é rentável, ou seja, econômica. 
Quadro - 3. Componentes e resultados da equação de economia de custo da fluoretação da água proposta por HADDIX (1996) .

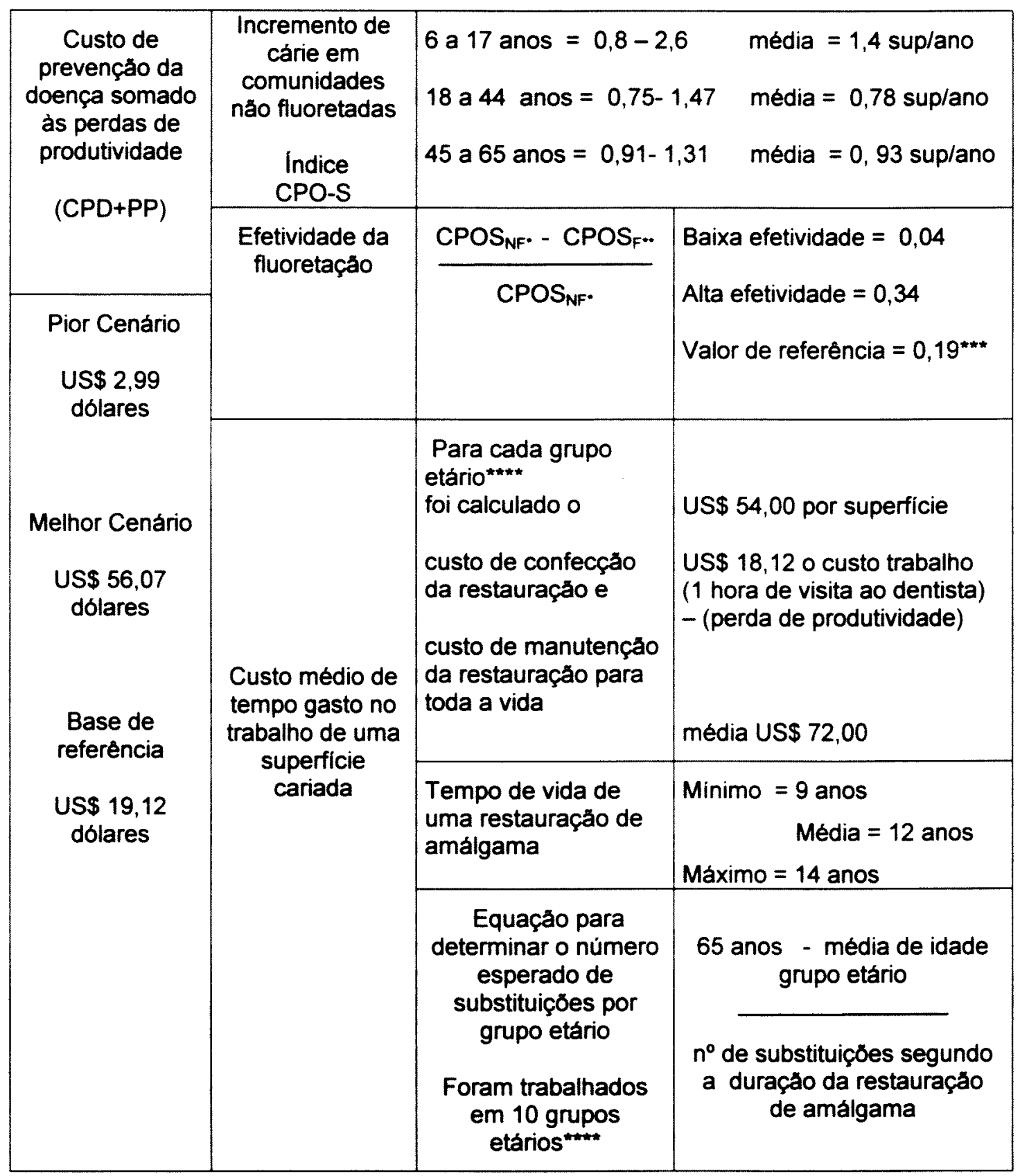

${ }^{*} \mathrm{CPOS}_{\mathrm{NF}}$ populaçăo residente em cidades não fluoretadas.

${ }^{*}{ }^{*} \mathrm{CPOS}_{F}$ populaçăo residente em cidades fluoretadas

** Numero de superfícies prevenidas pela cárie após um ano de fluoretaçăo

*** Grupos etários: $6-19 ; 20-24 ; 25-29 ; 30-34 ; 35-39 ; 40-44 ; 45-49 ; 50-54 ; 55-59 ; 60-64$. 
BARBISAN et al (1970) estimaram o custo da fluoretação na cidade de Curitiba, em 1968, em Cr\$ 0,288 por familia ano e em Cr\$ 0,06 por pessoa/ano, tendo como base que o custo da adição de flúor $\left(\mathrm{F} / \mathrm{m}^{3}\right)$ de água tratada foi de Cr\$ 0,0012 . Segundo dados do DMAE e CORSAN (companhias de saneamento e abastecimento de água), o consumo mínimo de água foi de $20 \mathrm{~m}^{3}$ mensal por familia, onde o custo por $\mathrm{m}^{3}$ de água tratada foi de Cr\$ 0,24 para a DMAE e CR $\$ 0,39$ mensal para a CORSAN. Nessas condições o custo da fluoretação representou $0,5 \%$ e $0,3 \%$, respectivamente, do custo final de tratamento de água $\left(\operatorname{Cr} \$ 0,0012\right.$ por $\left.\mathrm{m}^{3}\right)$. Na composição dos custos BARBISAN et al (1970) incluíram o produto quimico (flúor) e o gasto com energia elétrica. $O$ custo com pessoal para fluoretação não foi incluido pois, segundo os autores, não há necessidade de pessoal adicional para operar adição do flúor.

Em trabalho apresentado no $65^{\circ}$ Congresso Odontológico Mundial, da Federação Dentaria Internacional (FDI), realizado em 1977 em Toronto, Canadá, Flávio Luce, um dos pioneiros da fluoretação no Brasil, relatou que o custo da fluoretação da água, no Brasil, em 1975, fora de Cr\$ 1,00 por pessoa/ano, o que representava US\$ 0,06 (1 dólar americano equivalia a Cr\$ 15,00 em 1975). No Rio Grande do Sul, o custo seria de Cr\$ 1,50 por pessoa/ano ou US\$ 0,09 (LUCE 1977).

Estima-se que o custo relativo de aplicação de flúor esteja em cerca de R\$ 0,60 per capita/ano no Brasil (NARVAI 1997). GARCIA (1989) estimou o custo nos Estados Unidos variando de um mínimo de 
US\$ 0,12 per capita/ano, para cidades com mais de 200.000 habitantes a um máximo de US\$ 5,41 per capita/ano, para cidades com menos de 10.000 habitantes. O custo médio fica em torno de US\$ 0,51 per capita/ano. Considerando que nos Estados Unidos a inflação anual média é de 4\%, este valor seria irrisório segundo BURT (1989).

NEWBRUN (1978) apud PINTO (2000) estimou que para cada dólar empregado em fluoretação das águas, tem-se uma economia de 50 vezes em relação aos gastos com assistência em saúde bucal.

Segundo NEWBRUN (1996), o custo de fluoretação por pessoa/ano nos EUA, na década de 80 foi em média US $\$ 0,25$ podendo chegar até US $\$ 0,50$ por pessoa/ano. O custo do tratamento ocorrido com o incremento de cárie teve uma variação média de US $\$ 38,00$ a US $\$ 42,00$ por pessoa/ano.

A Secretaria de Estado de Saúde do Paraná divulgou que o custo da fluoretação das águas de abastecimento para o Estado do Paraná, no ano 2000 foi $R \$ 0,15$ por pessoa/ano e $R \$ 0,75$ por familia/ano, sendo que a população total abastecida por água fluoretada pela SANEPAR foi de 7.269 .947 pessoas. O custo total da fluoretação foi de $R \$ 1.089 .602,14$. Neste valor estão incluídos os custos da fluoretação propriamente dita e, também, os custos de controle operacional. (SESP 2003). 


\section{5 Índice CPO-D e Fatores sócio-econômicos}

$\mathrm{Na}$ saúde bucal coletiva, a busca para identificar um instrumento epidemiológico que pudesse refletir de maneira coerente o ataque da cárie dentária nas populaçōes não foi tarefa fácil, pois trata-se de uma doença multifatorial (THYLSTRUP e FEJERSKOV 1988), onde cada superfície dentária apresenta uma suscetibilidade distinta e cada tipo de dente pode refletir uma experiência de ataque de cárie distinta devido as caracteristicas anatômicas e periodo de erupção (KLEIN, PALMER e KNUTSON 1936), (THYLSTRUP e FEJERSKOV 1988). Além disto, a incidência pode variar de indivíduo para indivíduo bem como em diferentes comunidades devido a fatores sociais, econômicos, culturais, ambientais, nutricionais e de acesso aos bens e serviços.

Assim, o processo de construção de um indice que pudesse refletir a prevalência de cárie dentária de comunidades com informações consistentes e confiáveis e que pudesse um indice ser reproduzido em outras comunidades para comparações ao longo do tempo foi objeto de estudo de vários pesquisadores. ODENTHAL (1887) na Alemanha, examinou o número de dentes cariados na população e o número de indivíduos livres da doença; FENCHEL (1893), identificou o número de dentes cariados segundo sexo; GUILLERMIN (1895 - Suíça), CUNNINGHAM (1908 - Inglaterra), CAMPETELLI (1931 - Itália), TOROFREILE (1933 - Equador) e KROHN (1935 - Dinamarca) levantaram dados sobre dentes atacados por cárie e porcentagem da população livre da 
doença. MUNBLATT em 1933 separou os individuos por grupos etários considerando a idade e o número de dentes irrompidos, separando os dentes decíduos dos permanentes e definindo a "porcentagem de incidência de cárie". O autor, também fez referência sobre o número de dentes com extração indicada e o número de dentes restaurados por pessoa.

Em 1937, KLEIN e PALMER realizaram um levantamento epidemiológico de cárie dentaria em jovens índios de 35 tribos americanas e propuseram um instrumento epidemiológico para mensurar e identificar a "taxa de ataque de cárie dentária" na dentição permanente em grupos populacionais. O Índice CPO-D sugerido é composto pelo número de dentes permanentes cariados, perdidos (por cárie) e obturados em relação ao total de pessoas examinadas. Os autores também introduziram o conceito de composição percentual de cada componente do indice em relação ao CPO-D total (KLEIN e PALMER 1937).

Desde este periodo, o índice CPO-D é o instrumento utilizado em estudos epidemiológicos sobre cárie dentária, sendo o que melhor descreve as condições e a prevalência de cárie dentária em comunidades, por isso é largamente empregado em levantamentos epidemiológicos (KNTSON 1947; SCHEININ et al 1964; DURAN e DEL PASSO 1970). O índice também é utilizado para mensurar os efeitos de programas de prevenção de cárie dentária que utilizam a fluoretação das águas de abastecimento público (AST et al 1956; BROWN et al 1959; FREIRE 1961; VIEGAS e VIEGAS 1974), além de ser também uma importante ferramenta 
para o planejamento de programas de assistência odontológica (VASCONCELOS 1959; CHAVES 1986; OMS 1987, 1997; NARVAI 1998).

Para mensurar e identificar o ataque de cárie em dentes deciduos, GRUEBBEL (1944), propôs o "índice ceo". Esse índice corresponde, num indivíduo, à soma do número de dentes (decíduos) cariados ("c"), com extração indicada ("e") e restaurados ("o").

Estudos demonstraram que, a partir da década de 70 , ocorreu uma significativa redução na prevalência da cárie dentária em crianças nos paises desenvolvidos (BURT 1994; DOWER 1994; PETERSSON 1996), constatando que, acompanhado da redução da prevalência, ocorreu o fenômeno conhecido como polarização da doença, caracterizado pela concentração dos mais altos indices da cárie em pequenos grupos populacionais dentro de um mesmo país ou região (BURTON et al 1984; BURT 1994; DOWNER 1994;), ocorrendo assim uma desigualdade na experiência de cárie dentária entre as classes sociais (AL-MOHAMMADI 1997).

Alguns autores destacam que, além do uso de produtos fluoretados, o declínio da cárie dentário ocorreu, em alguns paises, devido à melhora na higiene oral (OSCARSON et al 2003), à mudança no padrão de consumo de produtos açucarados (AINAMO 1987; SHEIHAM 1991; DOWNER 1999), à melhoria nas condições de vida da população (TREASURE e DEVER 1994; PINTO 1996; WEYNE 1997; MARCENES e BONEKER 2000; NADANOVSKY 2000), ao uso de antibiótico de forma 
indireta (SHEIHAM 1984; BIRKELAND et al 2000), à mudança nos critérios de diagnósticos dos levantamentos populacionais (AINAMO 1987).

Em pesquisas populacionais realizadas no Brasil, esta redução também é verificada em 1986 e 1996 (BRASIL 1988, 1998), além de levantamentos realizados em alguns municípios que dão destaque ao fenômeno da polarização da cárie dentária, como em Santos - SP, 1995 (MANFREDINI 1996; FSP/USP 1996), Blumenau - SC, 1998 (PERES 1998) e Florianópolis - SC, 1995 (PERES 1996).

Sendo assim, outros fatores interferem no processo saúdedoença da cárie dentária além da "Tríade de Keyes" (KEYES 1962), atingindo de maneira desigual os desiguais ou, segundo FREITAS (2001) "a cárie dentária é uma doença social", sendo influenciada por variáveis sócioeconômicas, demográficas e comportamentais.

PERES et al (2000), através de um estudo em Florianópolis, relacionou possiveis fatores para a alta severidade de cárie dentária (crianças com CPO-D > $=5$ comparado com crianças com CPO-D $=0$ ) e constatou que, crianças cujas familias apresentaram renda familiar menor que $5 \mathrm{sm}$ (salários minimos), tinham 4,18 vezes mais chances de apresentar alta severidade de cárie comparada com crianças cuja renda familiar é superior a $15 \mathrm{sm}$. Outra variável significativa, no modelo final, foi a freqüência de consumo de produtos cariogênicos. Crianças que consumiam estes produtos de duas a três vezes por dia, todos os dias, tinham 4,41 
vezes maior chance de ter alta severidade de cárie quando comparadas com crianças que consumiam no máximo uma vez ao dia.

Estudo realizado por BALDANI et al (2002), nos municípios do Estado do Paraná, comparou o indice CPO-D e alguns Indicadores de Desenvolvimento Social e observou que há uma correlação entre os niveis de prevalência de cárie e os niveis de pobreza. Municípios com piores indicadores educacionais apresentaram maior prevalência de cárie e nos municipios onde havia maior porcentagem de domicilios com ligação de rede de abastecimento de água, os valores do CPO-D foram menores.

Segundo BALDANI et al (2002), a "importância deste beneficio (água tratada), apresenta-se não só como um recurso para a redução dos niveis de cárie como também para atenuar o impacto das desigualdades sócio-econômicas" pois se observa-se que "grupos especificos da população permanecem com elevada prevalência de cárie dentária e apresentam maior vulnerabilidade ao agravo em associação mais intensa a fatores de risco e à privação social" (BALDANI et al 2002).

MALTZ et al (2001) observaram que os alunos que estudam em escolas públicas no Municipio de Porto Alegre - RS, tinham maior prevalência de cárie que os estudantes de escolas privadas. Com relação aos componentes do indice CPO-S, os alunos de escolas públicas apresentaram um número superior de superfícies de dentes cariados e perdidos enquanto que os alunos da rede privada apresentaram mais superficies de dentes restauradas. Estes resultados também foram 
observados nas pesquisas realizadas no municipio de São Vicente - SP, 1996 (FSP/USP - SS/SV 1996), e no municipio de São Paulo - SP, 1996 (SES/SP - FSP/USP 1997).

Fatores de privação social também têm impacto nos niveis de saúde bucal da população adulta. FRAZÃO et al (2003), analisando os resultados do estudo exploratório em trabalhadores de escolas no Estado São Paulo, observaram que a "experiência de cárie dentária em adultos residentes em cidades com água de abastecimento público fluoretada foi menor em comparação com adultos de cidades sem este benefício" e que "pessoas com renda inferior ou igual a meio salário mínimo apresentaram mais dentes cariados e perdidos". Os autores observaram uma correlação positiva entre os indicadores de IDH e renda familiar com o número de dentes restaurados e uma correlação negativa com o número de dentes perdidos do indice CPO-D. Outros estudos também relatam que adultos que têm o beneficio de água tratada têm menor prevalência no ataque de cárie (VIEGAS e VIEGAS 1988; HUNT 1989; STAMM 1990).

SAMPAIO (1993) relacionou o uso de flúor e a menor severidade de cárie dentária. FREYSKEBEN et al (2000) destacaram que o uso de dentifricios com flúor nos programas preventivos contribuiu para a redução na prevalência de cárie. Para NARVAl et al (2000b) além destes fatores, o acesso à água de abastecimento público com níveis adequados de flúor tem papel fundamental na redução da prevalência da cárie dentária. 


\section{OBJETIVOS}

A presente investigação teve os seguintes objetivos:

\subsection{Objetivo geral:}

Estabelecer uma estimativa do custo-efetividade da fluoretação das águas no município de São Paulo, no período de outubro de 1985 a 2003.

\subsection{Objetivos especificos:}

3.2.1 - Avaliar os níveis de cárie dentária no município de São Paulo, no periodo de outubro de 1985 a 2003, abrangendo 18 anos desde a implantação da fluoretação das águas de abastecimento público, tendo como indicador os valores do índice CPO-D na idade-índice de 12 anos.

3.2.2 - Obter informações em órgãos oficiais que permitissem admitir que a população do município de São Paulo foi exposta a níveis adequados de flúor nas águas de abastecimento público no período de 1985 a 2003.

3.2.3 - Estimar o valor gasto pela Companhia de Saneamento Básico do Estado de São Paulo (SABESP) com a fluoretação das águas no município de São Paulo no período de 1985 a 2003, bem como o custo per capitalano.

3.2.5 -Estimar os custos da fluoretação em sistemas de tratamento de água em municipios de 5.000 a 100.000 habitantes e compará-los com os custos obtidos para o município de São Paulo. 


\section{MATERIAL E MÉTODO}

\section{1 - Tipo de Estudo}

Trata-se de um estudo de caso, cujo objeto é a experiência de 18 anos de fluoretação das águas de abastecimento público no municipio de São Paulo (período de 1985 a 2003).

\section{2 - Material}

Levantou-se junto a SABESP, por meio de uma entrevista estruturada e documentos fornecidos pela empresa, informações referentes:

a) ao custo do ácido fluorsilícico e dos equipamentos necessários para a incorporação do flúor na água de abastecimento na cidade, considerando todas as Estações de Tratamento de Água (ETA);

b) ao custo de manutenção e tempo de vida estimado dos equipamentos para fluoretação;

c) porcentagem da população do municipio não coberta pela rede de tratamento de água;

d) a quantidade de flúor natural da água que chega nas ETA bem como a quantidade que a SABESP incorpora para obter a concentração ideal $(0,7 \mathrm{ppm})$;

e) o volume de água consumido pela população no município;

f) as estratégias adotadas pela SABESP com relação ao controle dos teores de flúor. 
Levantaram-se dados do controle dos teores de flúor realizado pela Secretaria Municipal da Saúde de São Paulo no periodo de 1990 até 2002.

Levantaram-se informações de empresas fornecedoras de equipamentos para a instalação do sistema de fluoretação.

Buscaram-se os dados na literatura cientifica para respaldar teórica e tecnicamente a pesquisa, referente aos temas: cárie dentária, flúor, fluoretação das águas, efetividade da fluoretação, controle dos teores de flúor, instalação de sistema de fluoretação, custo da fluoretação, custoefetividade e o custo-beneficio.

\section{3 - Dados da fluoretação}

Foram utilizados alguns recursos para a obtenção dos dados:

A. Entrevista estruturada (Anexo 1)

- Foram realizadas duas entrevistas com o Eng. Alexandre Saron SABESP - ETA Guaraú em 25/10/02 e 16/08/03.

B. Entrevista Aberta

- Eng. Alexandre de A. Rodrigues, engenheiro de aplicação da DIGIMED Instrumentação Analítica (DIGICRON Analítica LTDA.) empresa de fabricação de equipamentos de controle e análise de produtos químicos, realizada em 25/08/03. 
C. Visitas

- Visitas à ETA Guaraú - para conhecer o sistema de tratamento de água, o processo de fluoretação e o controle operacional de monitoramento e dosagem do flúor, realizadas em 25/10/02 e 16/08/03.

- Visita à DIGIMED instrumentação analítica (DIGICRON Analítica LTDA.) - empresa de fabricação de equipamentos de controle e análise de produtos químicos, para a apresentação dos modelos de equipamentos para o controle de flúor: (aparelho colorímetro portátil, medidor de bancada microprocessado com eletrodo de flúor e o medidor de flúor em tempo real com saida para controle de bomba dosadora) além dos custos dos mesmos, realizada em 25/08/03.

D. Contato telefônico e por correspondência eletrônica (e-mail)

- Eng. Alexandre Saron (SABESP - ETA Guaraú).

- Sr. Osvaldo Yoshio Niida e Sr. Cicero Mirobo Rocha Filho (SABESP - Divisão de Macro Medição e Controle).

- Gerente Carlos Eduardo de Oliveira Sesso (SABESP Superintendência de Suprimentos). 


\section{E. Documentos disponibilizados}

a) SABESP

- Boletim diário de controle operacional - produtos químicos (relatório diário no qual constam informaçōes coletadas de hora em hora sobre a dosagem de produtos químicos como sulfato de alumínio, cal virgem, cloreto férrico, sulfato férrico, polieletrólito, cloro e ácido fluorsilícico, com valores médios diários, além dos valores máximos e mínimos encontrados).

- Boletim diário de controle operacional - laboratório (relatório diário com informaçōes dos dados das análises, realizadas de hora em hora, referentes a: $\mathrm{pH}$, potencial zeta laser, turbidez, cor, cloro residual livre, flúor, metais, alcalinidade e nome do técnico responsável pelas análises, bem como o relatório da contra prova dos testes, incluindo o horário da coleta com valores médios, máximo, e minimo diários.

- Relatório de monitoramento do sistema produtor integrado da Região Metropolitana de São Paulo - mensal (relatório mensal com dados das análises realizadas diariamente dos testes químicos, teor de flúor, análises bacteriológicas, resultados da média mensal dos valores máximos e mínimos encontrados, o desvio padrão da distribuição de freqüência das análises, o intervalo de confiança para $95 \%$ de parâmetros e o limite inferior e superior. A partir destes dados e com cada um dos resultados da 
análise dos produtos é realizada uma curva "t de student" obtendo assim a probabilidade de atendimento aos padrões. Todos os resultados são multiplicados entre si e deste resultado se aplica a raiz à nona obtendo o índice de performace (IP) dos resultados mensais.

- Controle de estoque de produtos químicos (relatórios diários do estoque, das entradas, consumo e devolução, segundo cada um dos produtos químicos utilizados para o tratamento de água, além de conter também neste relatório a leitura dos tanques de estoque dos produtos e um relatório das empresas, com as quantidades de cada produto que foi descarregado na ETA, além do $n^{\circ}$ da nota fiscal correspondente).

- Dados sobre o volume de água tratada em $\mathrm{m}^{3}$ na ETA Guaraú, de 1974 até 2003 (dados anuais), dados mensais do consumo em toneladas de ácido fluorsilícico de nov/1985 até dez/2003 e a relação entre $\mathrm{Kg}$ de flúor para cada $1.000 \mathrm{~m}^{3}$ de água tratada por ano.

- Relatório mensal da operação - custo mensal (relatório dos custos dos produtos químicos utilizados e volume correspondente: sulfato de alumínio, cal virgem, cloro líquido, ácido fluorsilícico, polieletrólitos, cloreto férrico e sulfato férrico). Também são apresentados os gastos com pessoal: salários e encargos, gastos com energia elétrica (os custos e o consumo mensal em $\mathrm{kWh}$ ), os 
custos de despesas internas e os custos de transportes. Tem-se assim o custo total da água aduzida, o volume de água tratada e o custo para cada $1.000 \mathrm{~m}^{3}$ de água mensal (relatórios de janeiro de 1998 a dezembro de 2003).

b) Fornecedores

- DIGIMED Instrumentação Analítica (DIGICRON Analitica LTDA.) - documentos técnicos sobres os equipamentos, o manual para o uso de eletrodos de flúor e o manual do analisador on-line de flúor. Também foi levantado o custo médio de uma bomba dosadora de vazão de água.

- POLICONTROL Instrumentos de Controle Ambiental, Industrial e Comercio Ltda. - documento técnico sobre equipamento de dosagem dos teores de flúor.

\section{4 - Heterocontrole}

Para aferir o teor de flúor adicionado às águas na cidade, foram solicitados dados à Secretaria Municipal da Saúde de São Paulo (SMS-SP) sobre a vigilância sanitária (heterocontrole) do flúor nas águas de abastecimento, considerando os diversos pontos do território do municipio. A SMS-SP dispunha dessas informaçōes para o período de 1990 a 2003.

A finalidade era comparar os dados disponiveis do controle dos teores de flúor realizados pela SABESP e os dados da SMS-SP; verificar períodos de níveis abaixo do recomendado (falta de efetividade) ou acima do 
recomendado (risco a saúde); observar o possivel impacto no aumento dos custos da fluoretação decorrente da falta do produto no mercado, pois como o Ácido Fluorsilícico $\left(\mathrm{H}_{2} \mathrm{SiF}_{6}\right)$ é subproduto da indústria de fertilizantes, sua produção tende a ser sazonal.

\section{5 - Referencial Epidemiológico}

Analisaram-se os dados epidemiológicos relativos à cárie dentária disponiveis para o periodo anterior a fluoretação (17 anos) (1969 até 1986) e nos 16 anos posteriores à fluoretação das águas de abastecimento público no município de São Paulo (1986 até 2002) para avaliar a mudança no quadro epidemiológico ocorrida antes e depois de iniciada a fluoretação.

Para analisar a situação da cárie dentária na população paulistana, no período do estudo, foram utilizados dados epidemiológicos produzidos por diferentes pesquisas, a saber:

A) - Índice CPO-D, índice de ataque e número de dentes irrompidos. Comportamento em escolares do Município de São Paulo, São Paulo, 1970 (SOUZA 1970);

B) - Caracteristicas epidemiológicas da cárie dental na dentição permanente de escolares do grupo etário de 7 a 14 anos no Estado de São Paulo. São Paulo, 1987 (Municipio de São Paulo, dados de 1980 - 1982) (ROSA 1987);

C) - Levantamento epidemiológico de cárie dentária em escolares no municipio de São Paulo, 1984 (SÃO PAULO 1985); 
D) - Levantamento epidemiológico em saúde bucal. Brasil, zona urbana, 1986 (BRASIL 1988);

E) - Levantamento epidemiológico de cárie dentária - Brasil, 27 capitais, 1996 (MINISTÉRIO DA SAÚDE 1996);

F) - Levantamento epidemiológico da cárie dentária, oclusopatias e fluorose dentária, em crianças de 5 a 12 anos de idade, em escolas públicas e privadas do município de São Paulo, 1996 (SES-SP/FSP-USP 1997);

G) - Levantamento epidemiológico em saúde bucal: Estado de São Paulo, 1998 (SES-SP/FSP-USP 1999);

H) - Condições de saúde bucal no Estado de São Paulo em 2002 (SES-SP/FSP-USP 2002).

Com base nos dados epidemiológicos proporcionados por esses estudos de base populacional, a comparação permitira a projeção da mudança do quadro epidemiológico, a efetividade da fluoretação das águas de abastecimento público sobre a cárie dentária. 


\section{RESULTADOS}

\subsection{Caracterização do Municipio}

Em 1554 foi fundado o povoado denominado São Paulo de Piratininga. Em 22/03/1681 o povoado foi elevado à categoria de sede da Capitania. Elevando-se à categoria de Provincia em 16/12/1815 (SEADE 2003).

O município está situado na região leste do Estado de São Paulo e sudeste do Brasil. Ocupa, segundo o Instituto Brasileiro Geográfico e Cartográfico (IBGC), uma área territorial de $1.509 \mathrm{Km}^{2}$. Segundo o Censo Demográfico-1970, a cidade de São Paulo contava com uma população de 5.924.615 habitantes. Em 1980 apresentava 7.114.258 habitantes e, em 1991, a cifra era de 9.646.185 habitantes (IBGE 1970, 1980, 1991). Em 2000 a cidade de São Paulo contava com uma população de 10.398.576 habitantes (SEADE 2003).

Observa-se uma diminuição no crescimento demográfico de São Paulo na última década, em comparação com as décadas anteriores, de $70 / 80$ e $80 / 91$. A taxa de crescimento anual da população no período de 1991/2000 foi de $0,91 \%$ ao ano, (SEADE 2003).

O Índice de Desenvolvimento Humano Municipal (IDH-M) é um indicador que agrega os indices de longevidade (esperança de vida ao nascer), índice de educação (número médio de anos de estudo e a taxa de analfabetismo da população acima de 15 anos) e a renda familiar per capita, 
classificando os municipios em uma escala de 0 a 1. Em 2000 o IDH-M do municipio era de 0,841 valor que, segundo o PNUD (Programa das Nações Unidas para o Desenvolvimento), representa uma cidade com alto desenvolvimento humano (acima de 0,800).

A taxa de analfabetismo na população acima de 15 anos na cidade era $4,9 \%$ em 2000, de acordo com a Fundação SEADE (2003). No Brasil, em 2000, esta taxa foi de 13,1\% segundo o IBGE (2003).

A renda dos responsáveis pelos domicílios na cidade de São Paulo, em 2000, sem nenhum rendimento ou com rendimento de até 1 salário mínimo (sm) era de 16,84\%; entre os que tem rendimentos superior a $1 \mathrm{sm}$ e até $3 \mathrm{sm}$ refere-se a $23,22 \%$; com rendimento superior a $3 \mathrm{sm}$ e até 5 sm representa $17,92 \%$; com mais de 5 e até $10 \mathrm{sm}$ equivale a $20,95 \%$, e com rendimento que maior que 10 salários mínimos é de $21,07 \%$. 0 rendimento médio dos responsáveis pelo domicílio era de $R \$ 1.478,69$ em julho de 2002 (SEADE 2003). Estes dados refletem uma grande desigualdade na distribuição de renda na cidade.

O município de São Paulo é a maior cidade do país em população, desenvolvimento econômico e geração de renda. Apesar disto, apresenta forte desigualdade social e desequilibrio na distribuição de renda, refletindo o que ocorre em âmbito nacional.

Segundo o BIRD (Banco Mundial), o Brasil é o país mais desigual da América Latina e está entre os dez mais desiguais do planeta. Estes dados são obtidos através do índice Gini (escala de $0-1$ ), que mede 
a desigualdade social. Nos anos 90 , o índice Gini para o Brasil era 0,59, já em 2002 ele diminuiu para 0,57. Apesar da pequena queda na última década, esta não teve impacto significativo para a mudança do quadro de desigualdade social, e para alteração no desequilibrio na distribuição de renda.

O municipio de São Paulo apresenta características gerais de morbidade e mortalidade que permitem situá-la na denominada "transição epidemiológica", uma vez que padrões epidemiológicos típicos das regiōes menos desenvolvidas do país coexistem com perfis de morbi-mortalidade que se assemelham ao de paises desenvolvidos (NARVAI 2001).

Um dos indicadores de saúde utilizados para refletir a melhoria ou a piora nas condições básicas de vida é o Coeficiente de Mortalidade Infantil (CMI), que mede o número de óbitos na população menor de um ano e tem como denominador o total de nascidos vivos naquela cidade no ano especifico (base 1.000 nascidos vivos). Em 1970, o CMI na cidade era de 89,5\%; em 1980 o CMI era de 50,6\%; em 1990 o CMI era de 30,9\%o; em 2000 o CMI era de 15,8\%; e em 2002 o CMI era de $15,1 \%$ segundo dados da Fundação SEADE (2003). A mortalidade infantil teve uma queda expressiva na última década reduzindo-se pela metade, porém não ocorrendo de forma uniforme por toda a cidade. Há regiōes onde o CMI é menor que $6 \%$ enquanto que, em regiões mais periféricas, atinge $24 \%$ o óbitos; refletindo assim a grande desigualdade nas condiçōes de vida e no 
acesso aos serviços de saúde nas diferentes regiões da cidade de São Paulo (PMSP 2003).

Em relação ao acesso da população à água tratada, dados mostram que em $1980,94 \%$ da populaçăo recebiam este beneficio e $44 \%$ dos domicilios tinham ligações da rede de esgoto, segundo a SABESP (2003). Em dezembro de 1994 houve um aumento da população com acesso à água tratada, atingindo $100 \%$ e $80 \%$ dos domicílios com coleta de esgoto. No ano $2002100 \%$ da população tinham água tratada e $90 \%$ dos domicilios apresentavam coleta de esgoto (SABESP 2003).

Segundo dados da Fundação IBGE sobre o saneamento no Brasil em 2000 (IBGE 2004), o município de São Paulo é o que tem melhor cobertura da rede de abastecimento de água no país. A capital paulista apresenta $98,6 \%$ da população com acesso a rede de abastecimento público de água e $87,2 \%$ com acesso a rede de esgoto. Muitos distritos administrativos apresentam uma cobertura de $99,9 \%$ da população com acesso a rede de água sendo, que apenas em três distritos, a taxa de cobertura é inferior a $90 \%$, são eles Anhangüera (86,5\%), Parelheiros $(59,3 \%)$ e Marsilac $(0,95 \%)$.

Segundo os dados do IBGE, $1,4 \%$ da população não têm acesso a água tratada correspondendo a aproximadamente 149.092 habitantes no município de São Paulo, em 2000 (IBGE 2004). 
No tocante ao aspecto dos serviços de saúde, o município contava, em 2000, com 15.889 leitos do SUS (Sistema Único de Saúde), uma relação de 1,53 leitos por mil habitantes.

Apesar do Sistema Único de Saúde - SUS ter sido implantado no Brasil a partir da Constituição de 1988 (BRASIL 1988), com a reorganização hierárquica das responsabilidades e atribuições das esferas federal, estadual e municipal no tocante as ações, ao acesso da população, à organização dos serviços, ao estabelecimento de prioridades, ao financiamento, como também à participação da população através dos conselhos de saúde e das conferências de saúde, a cidade de São Paulo apenas conseguiu municipalizar os serviços de saúde em 2002 e restabelecer os princípios doutrinários do SUS. Devido a gestões municipais anteriores que apresentaram políticas antagônicas de saúde, criando um sistema paralelo de saúde (PAS - plano de atendimento à saúde), trazendo marcas profundas para a saúde na cidade de São Paulo, o municipio deixou de receber financiamento federal e estadual para o setor. Neste período, três modelos de assistência na área da saúde coexistiam, o sistema do PAS, gerenciado por cooperativas; o SIMS (Sistema Integrado Municipal de Saúde), órgão da Secretaria Municipal de Saúde, além da Secretaria Estadual de Saúde que gerenciava quase que metade dos postos de atenção básica, o Programa de Saúde da Familia "QUALIS", além de alguns hospitais de atenção terciária. 
Com relação a recursos físicos e segundo dados da Secretaria Estadual de Saúde (SES), o município de São Paulo contava, no ano 2000, com 462 Unidades de Saúde de atenção básica e 769 equipamentos odontológicos instalados. Com relação a recursos humanos, o municipio contava com 1.343 cirurgiões dentistas (CD), 511 atendentes de consultório dentário (ACD) e 26 técnicos em higiene dental (THD) trabalhando em unidades de saúde municipais ou estaduais. Os dados de indicadores de avaliação e produtividade em 1998 mostraram que 12,15\% da população tiveram acesso à assistência odontológica e $14,19 \%$ da população de 0 a 14 anos de idade foram cobertos por procedimentos coletivos (SES-SP 2002).

\subsection{Dados Epidemiológicos}

Serão descritos a seguir os levantamentos epidemiológicos em saúde bucal referentes à cárie dentária, realizados em escolares no periodo de 1969 a 2002, no municipio de São Paulo. Os indices utilizados foram o CPO-D e ceo-d e seus componentes referentes à condição de cárie dentária. Todos os estudos são transversais, realizados a partir de amostras de escolares nas idades de 5 a 14 anos, porém nem todos os estudos pesquisaram todas as faixas etárias.

Estes estudos foram realizados em distintos momentos históricos visando atender diferentes necessidades com distintos pesquisadores e/ou órgãos governamentais e universidades valendo-se de diferentes delineamentos amostrais e metodologias para obtenção dos dados. 
O recurso metodológico de utilizar levantamentos de dados epidemiológicos ocorridos no período anterior a fluoretação (17 anos) (1969 até 1986) e nos 16 anos posterior a fluoretação das águas de abastecimento público no municipio de São Paulo (1986 até 2002) é uma estratégia de análise para a pesquisa, primeiro para observar a mudança no quadro epidemiológico ocorrido antes da fluoretação e após a fluoretação das águas no município. Segundo WHITE et al (1989), a determinação da efetividade da fluoretação das águas na prevenção da cárie dentária é influenciada pelo indice de cárie dentária no momento da fluoretação e as mudanças nos padrões da doença no tempo, levando em consideração o decréscimo natural dos padrões da doença, e a proporção de pessoas com maior risco de cárie dentária.

Na Tabela 5.1 são apresentados os dados da média do indice CPO-D nas idades de 7 a 12 anos nos estudos epidemiológicos realizados no município de São Paulo no período de 1969 a 2002 e o Intervalo de Confiança para $95 \%\left(\mathrm{IC}_{95 \%}\right)$ da média de parâmetros populacionais segundo o Desvio Padrão da amostra.

Nos Gráficos 5.1 a 5.6 são apresentadas as médias do índice CPO-D e o IC $95 \%$ nas diferentes pesquisas realizadas no período de 1969 a 2002 no municipio de São Paulo nas idades de 7 a 12 anos respectivamente. 
Tabela 5.1 - Média do Indice CPO-D e os Limites Inferiores (LI) e Limites Superiores (LS) para o IC $95 \%$, nas idades de 7 a 12 anos dos estudos epidemiológicos realizados no município de São Paulo no período de 1969 a 2002.

\begin{tabular}{cccccccccc}
\hline IDADE & $\mathbf{1 9 6 9}$ & $\mathbf{1 9 8 0}$ & $\mathbf{1 9 8 2}$ & $\mathbf{1 9 8 4}$ & $\mathbf{1 9 8 6}$ & $\mathbf{1 9 9 6}^{\mathbf{a}}$ & $\mathbf{1 9 9 6}^{\mathbf{b}}$ & $\mathbf{1 9 9 8}$ & $\mathbf{2 0 0 2}$ \\
\hline $\mathbf{7}$ & - & 2,18 & 2,12 & 2,12 & 2,07 & 0,24 & 0,46 & 0,30 \\
LI - LS & & $2,14-2,22$ & $2,07-2,17$ & - & $1,93-2,22$ & $0,15-0,33$ & $0,30-0,62$ & $0,16-0,44$ \\
$\mathbf{8}$ & 2,60 & 3,11 & 2,99 & 2,96 & 2,70 & 0,53 & 0,89 & 0,51 & - \\
LI - LS & $2,37-2,83$ & $3,07-3,15$ & $2,94-3,04$ & - & $2,56-2,84$ & $0,40-0,66$ & $0,68-1,10$ & $0,31-0,71$ \\
$\mathbf{9}$ & 3,43 & 3,86 & 3,59 & 3,56 & 3,59 & 0,75 & 1,12 & 1,05 & - \\
LI - LS & $3,18-3,68$ & $3,81-3,91$ & $3,53-3,65$ & - & $3,42-3,75$ & $0,59-0,91$ & $0,92-1,32$ & $0,77-1,33$ \\
10 & 4,47 & 4,59 & 4,43 & 4,13 & 4,11 & 1,15 & 1,34 & 1,12 \\
LI - LS & $4,14-4,80$ & $4,52-4,66$ & $4,35-4,51$ & - & $3,88-4,34$ & $0,94-1,36$ & $1,10-1,58$ & $0,85-1,39$ \\
11 & 4,91 & 5,82 & 5,44 & 5,20 & 5,17 & 1,56 & 1,85 & 1,61 \\
LI - LS & $4,41-5,41$ & $5,73-5,91$ & $5,34-5,55$ & - & $4,85-5,49$ & $1,28-1,84$ & $1,55-2,15$ & $1,27-1,95$ \\
12 & 6,91 & 7,03 & 6,44 & 6,25 & 6,47 & 2,06 & 2,28 & 2,06 \\
LI - LS & $6,12-7,70$ & $6,92-7,14$ & $6,31-6,57$ & - & $6,12-6,82$ & $1,85-2,27$ & $1,88-2,68$ & $1,58-2,54$ & $1,48-2,02$ \\
\hline
\end{tabular}

Fonte: 1969 - SOUZA (1970); 1980 - 1982 - ROSA (1987); 1984 - Secretária Municipal da Educaçăo SP,(1984); 1986 - Ministério da Saúde (1988); $1996^{a}$ - Séc. Estado da Saúde / Fac. Saúde Pública (1997); $1996^{b}$ Ministério da Saúde (1996); 1998 - Séc. Estado da Saúde / Fac. Odontologia USP (1999); 2002 - Séc. Estado da Saúde (2002) 
Gráfico 5.1 - Média do índice CPO-D, Limite Inferior e Limite Superior do $I_{95 \%}$ para a média populacional, na idade de 7 anos de 1969 a 1998. São Paulo.

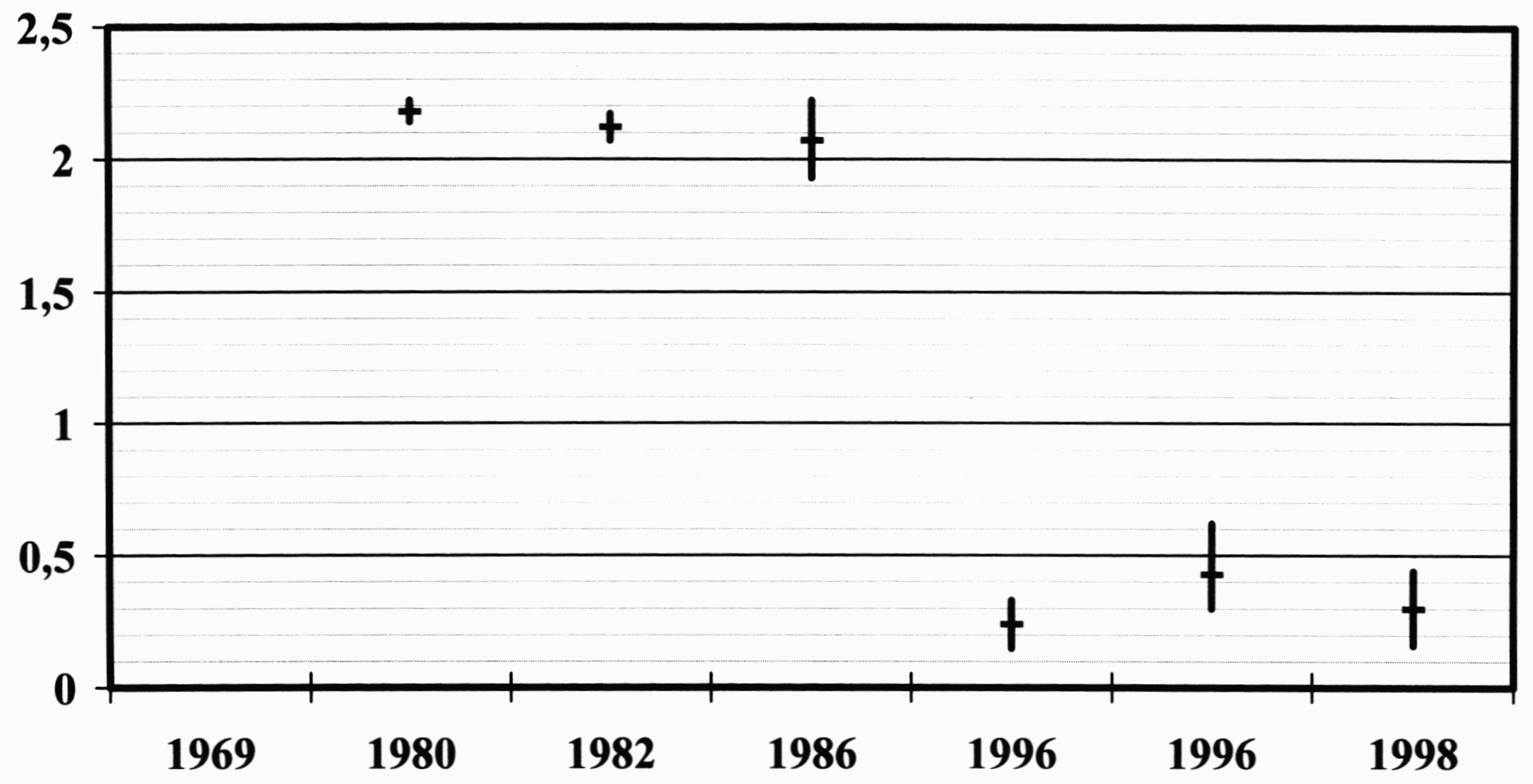


Gráfico 5.2 - Média do índice CPO-D, Limite Inferior e Limite Superior do $\mathrm{IC}_{95 \%}$ para a média populacional, na idade de 8 anos de 1969 a 1998. São Paulo.

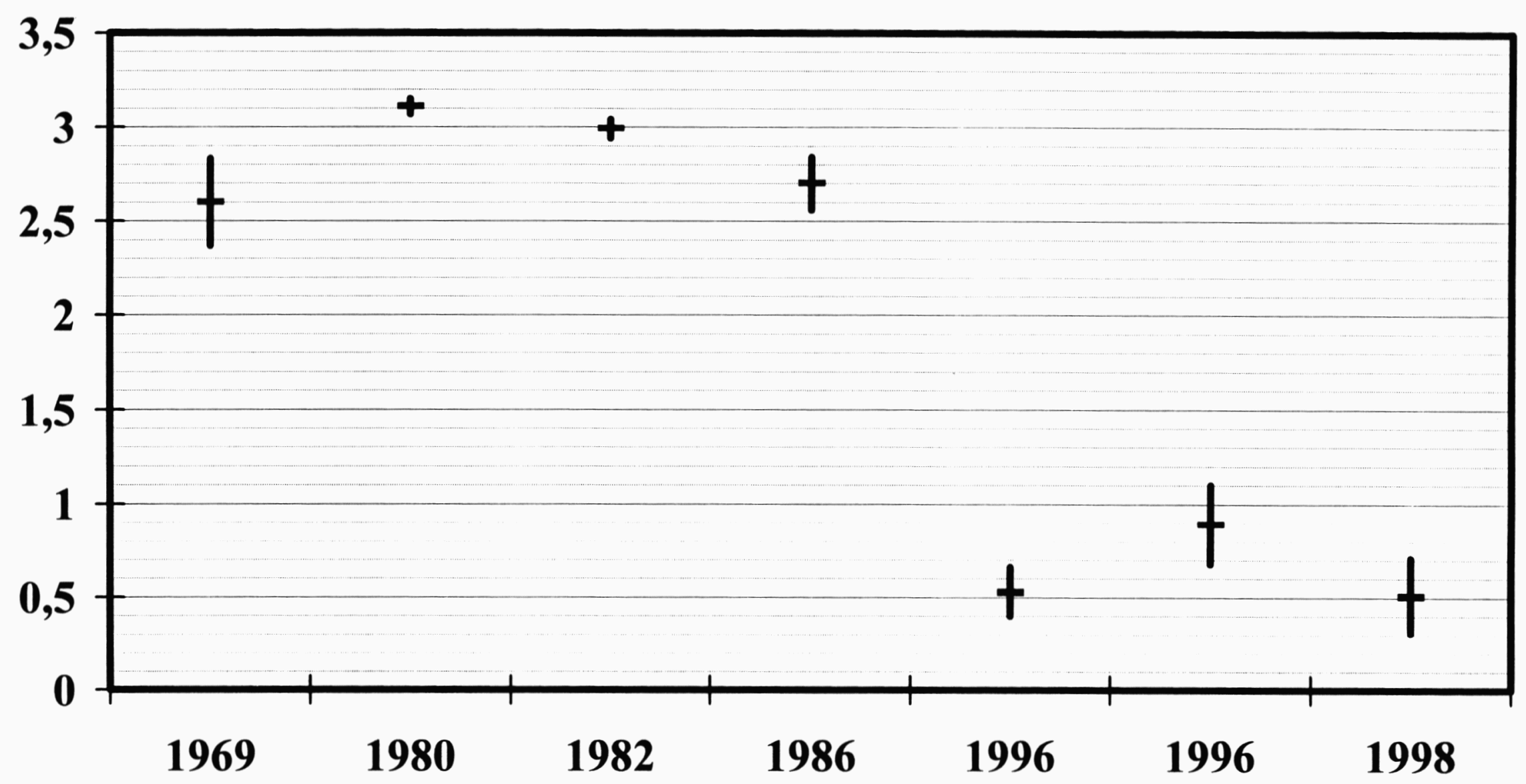


Gráfico 5.3 - Média do índice CPO-D, Limite Inferior e Limite Superior do $\mathrm{IC}_{95 \%}$ para a média populacional, na idade de 9 anos de 1969 a 1998. São Paulo.

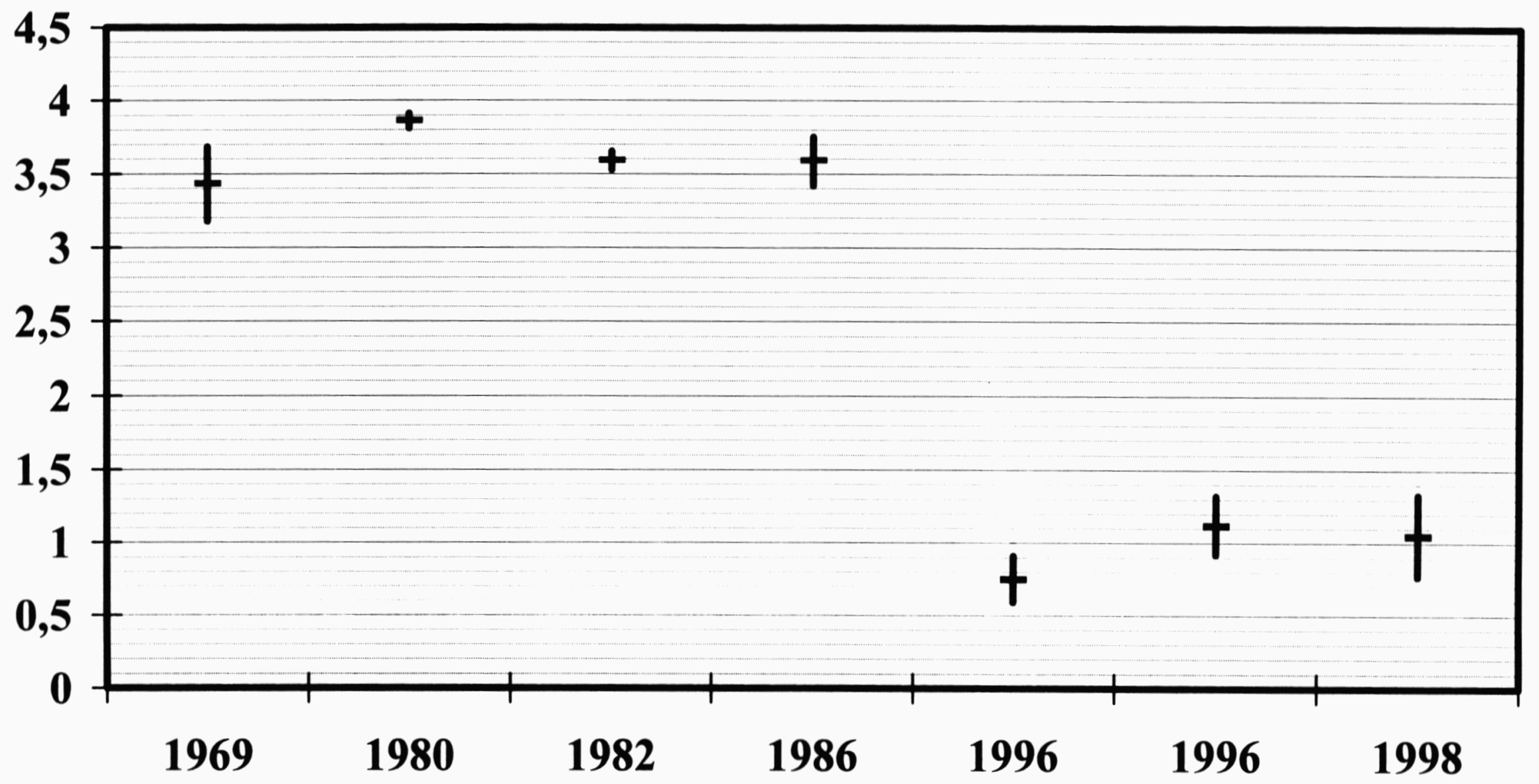


Gráfico 5.4 - Média do índice CPO-D, Limite Inferior e Limite Superior do IC $95 \%$ para a média populacional, na idade de 10 anos de 1969 a 1998. São Paulo.

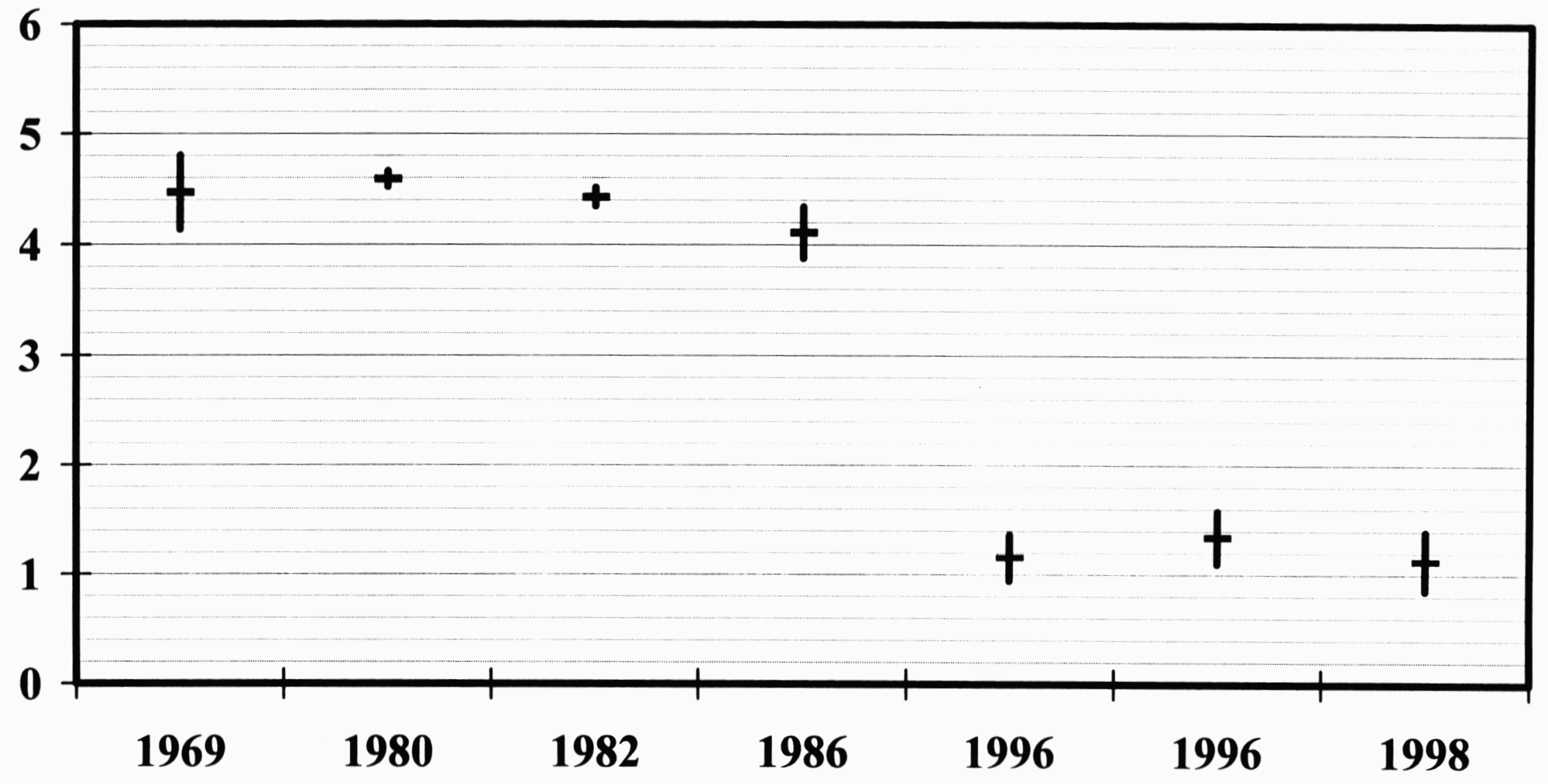


Gráfico 5.5 - Média do índice CPO-D, Limite Inferior e Limite Superior do $\mathrm{IC}_{95 \%}$ para a média populacional, na idade de 11 anos de 1969 a 1998. São Paulo.

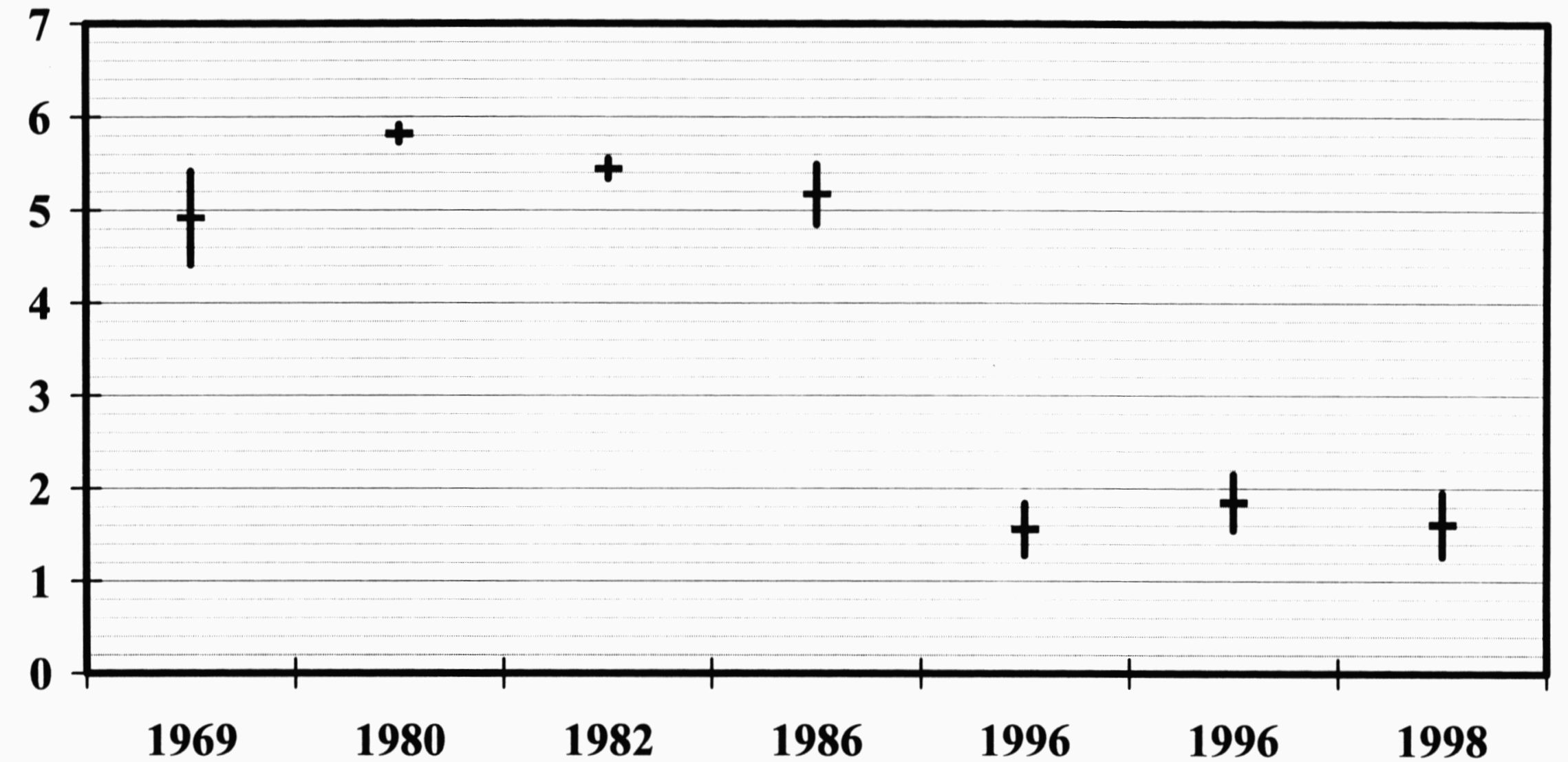


Gráfico 5.6 - Média do índice CPO-D, o Limite Inferior e Limite Superior do IC $_{95 \%}$ para a média populacional, na idade de 12 anos de 1969 a 2002. São Paulo.

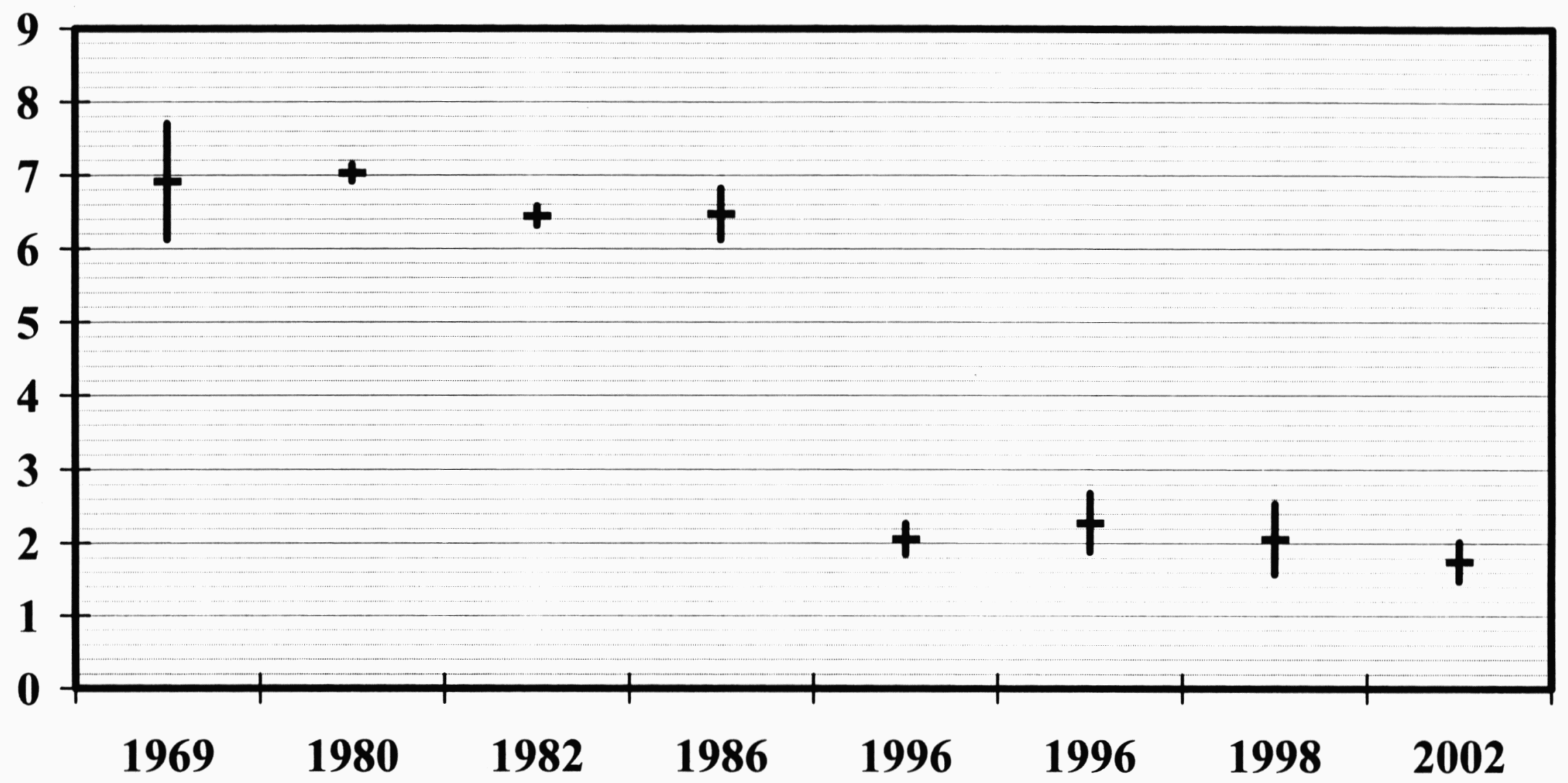


Na Tabela 5.2 são apresentados os dados da média do indice ceo-d nas idades de 5 a 10 anos nos estudos epidemiológicos realizados no municipio de São Paulo no período de 1983 a 2002.

Tabela 5.2 - Média do Índice ceo-d nas idades de 5 a 10 anos dos estudos epidemiológicos realizados no município de São Paulo no período de 1983 a 2002.

\begin{tabular}{cccccc}
\hline IDADE & $\mathbf{1 9 8 3}$ & $\mathbf{1 9 9 6}^{\mathbf{a}}$ & $\mathbf{1 9 9 6}^{\mathbf{b}}$ & $\mathbf{1 9 9 8}$ & $\mathbf{2 0 0 2}$ \\
\hline 5 & 5,22 & 1,70 & & 1,55 & 1,81 \\
6 & 5,27 & 1,45 & 2,14 & 1,59 & \\
7 & 5,23 & 1,96 & 2,52 & 1,67 & \\
8 & 4,12 & 2,09 & 2,28 & 2,19 & \\
9 & 3,03 & 1,81 & 2,13 & 1,58 & \\
10 & 2,56 & 1,29 & 1,62 & 1,04 & \\
\hline
\end{tabular}

Fonte: 1983 - Secretaria Municipal da Educaçăo SP,(1984); 1996ª - Sec. Estado da Saúde / Fac. Saúde Pública (1997); $1996^{\mathrm{b}}$ Ministério da Saúde (1996); 1998 - Sec. Estado da Saúde / Fac. Odontologia USP (1999); 2002 - Sec. Estado da Saúde (2002).

Na Tabela 5.3 são apresentados os dados da porcentagem de crianças de 12 anos de idade livres de cárie dentária (CPO-D =0) e o Intervalo de Confiança para $95 \%\left(\mathrm{IC}_{95 \%}\right)$ de parâmetros populacionais segundo o Desvio Padrão da amostra, nos estudos epidemiológicos realizados no município de São Paulo no período de 1969 a 2002. 
Tabela 5.3 - Porcentagem de crianças de 12 anos livres de cárie dentária (CPO-D = 0), Limite Inferior (LI) e Limite Superior (LS) da distribuição de freqüência do $I_{95 \%}$, município de São Paulo, período de 1969 a 2002.

\begin{tabular}{cccccc}
\hline 12 anos & 1969 & 1986 & $1996^{\star}$ & 1998 & 2002 \\
\hline $\begin{array}{c}\% \text { com } \\
\text { CPO-D }=\mathrm{O}\end{array}$ & 4,12 & 5,1 & 39,8 & 43,2 & 39,75 \\
LI - LS & $1,32-9,65$ & $3,26-7,69$ & $35,55-44,16$ & $34,72-51,99$ & $33,82-45,94$ \\
\hline
\end{tabular}

Fonte: 1969 - SOUZA (1970); 1986 - Ministério da Saúde (1988); $1996^{a}$ - Sec. Estado da Saúde / Fac. Saúde Pública (1997); 1998 - Sec. Estado da Saúde / Fac. Odontologia USP (1999); 2002 - Sec. Estado da Saúde (2002).

O gráfico 5.7 apresenta a porcentagem de crianças livres de cárie dentária na dentição permanente $(C P O-D=0)$ e $\circ I C_{95 \%}$ na idade de 12 anos nos levantamentos epidemiológicos realizados na cidade de São Paulo no período de 1969 a 2002. 
Gráfico 5.7 - Porcentagem de crianças com CPO-D = Zero, Limite Inferior e Limite Superior do IC $95 \%$ para a média populacional, na idade de 12 anos de 1969 a 2002. São Paulo.

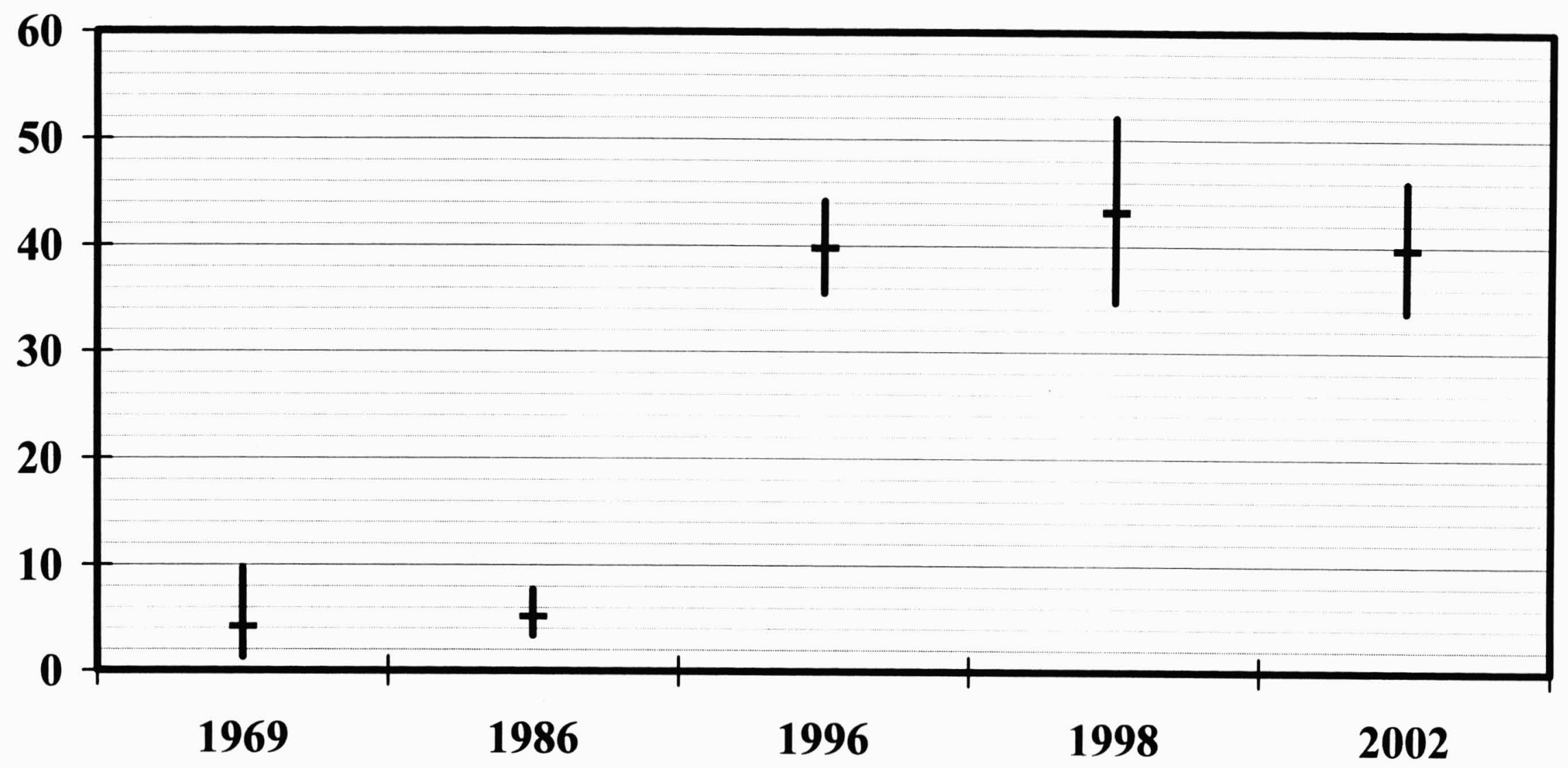




\subsection{Heterocontrole}

A Lei Federal $n^{\circ} 6050 / 74$ tornou obrigatória a fluoretação das águas de abastecimento público em todo o território brasileiro (BRASIL 1976). No Estado de São Paulo a Resolução SS-250/95, de 15/8/95, estabeleceu que, para os municipios do Estado de São Paulo, as águas tratadas para abastecimento público devem conter $0,7 \mathrm{mg}$ de flúor por litro (0,7 ppm), sendo aceitável uma variação no teor de 0,6 a $0,8 \mathrm{mgF} / \mathrm{L}$ onde teores abaixo ou acima deste intervalo caracterizam a água como "fora do Padrão de Potabilidade" (SÃO PAULO 1995).

Segundo MAIER (1971), a eficácia preventiva da fluoretação das águas de abastecimento público, em relação à cárie dentária, depende da continuidade da medida ao longo do tempo. Para CHAVES et al (1953), a interrupção permanente faz cessar os benefícios; a adição de pequenas quantidades do produto torna a medida inócua e a adição de quantidades excessivas de flúor pode causar fluorose dentária.

Para NARVAI (2001), é indispensável um controle permanente da fluoretação das águas de abastecimento público.

Este controle dos niveis de flúor nas águas de abastecimento público pode e deve ser realizado por dois métodos: "o controle operacional, realizado pela empresa de tratamento de água, integrado ao conjunto de procedimentos de controle da operação nas estações de tratamento de água $(E T A)$ e o "heterocontrole, realizado pelos órgãos de vigilância sanitária do poder executivo, com o objetivo de assegurar que o produto oferecido ao 
consumo da população atenda aos dispositivos legais e não apresente riscos à saúde humana" (NARVAl 2000c).

A empresa responsável pelo tratamento e distribuição de água na cidade de São Paulo é a SABESP e, assim, o controle operacional dos niveis de flúor na água de abastecimento é realizado nas Estações de tratamento de água através de três métodos diferentes. O primeiro método é realizado através de um medidor digital on-line ligado diretamente à bomba de dosagem onde é realizado o controle contínuo dos niveis de flúor. $O$ segundo método ocorre através de medições a cada hora durante as 24 horas do dia por meio de um sistema digital com eletrodos de ions seletivo. O terceiro método de controle se dá através de uma análise diária realizada em um laboratório central, cujos resultados são apresentados através de documento diário, "Boletim diário de controle operacional - Laboratorial" e de um relatório mensal de controle da qualidade da água (cloro, $\mathrm{pH}$, cor, turbidez, metais, teste bacteriológico e o flúor), o "Monitoramento de Sistema produtor integrado da RMSP".

O heterocontrole é realizado no municipio de São Paulo desde janeiro de 1990 pela Prefeitura Municipal de São Paulo através da Secretaria Municipal da Saúde (SÃO PAULO 1990; SCHNEIDER FILHO et al 1992), quando eram coletadas amostras mensais em 60 pontos distribuídos pelo território do município, em 1993 passaram a ser 62 pontos, em 1997 foram observados 63 pontos e em 2001 a coleta de água para análise se deu em 62 pontos da capital. Após as análises quimicas, os resultados são enviados 
para o nivel central da SMS-SP onde os dados são analisados e um relatório é elaborado (NARVAI 2001; SÃO PAULO 2001, 2002, 2003, 2004).

Os resultados do heterocontrole realizado no município de São Paulo no período de 1990 a 1999 foram analisados por NARVAI (2001), e nos anos de 2000 a 2003 foram obtidos através dos relatórios municipais (SÃO PAULO 2001, 2002, 2003,2004). O gráfico 5.8 apresenta os dados das condições das amostras segundo a fluoretação da água no municipio de São Paulo no período de 1990 a 2003. As amostras foram classificadas segundo os teores de flúor (teor aceitável na faixa de 0,6 a 0,8 mgF/L (ppm), e teor inaceitável acima ou abaixo desta faixa).

Gráfico 5.8 - Resultados do heterocontrole de flúor nas amostras das águas de abastecimento no período de 1990 a 2003 no município de São Paulo.

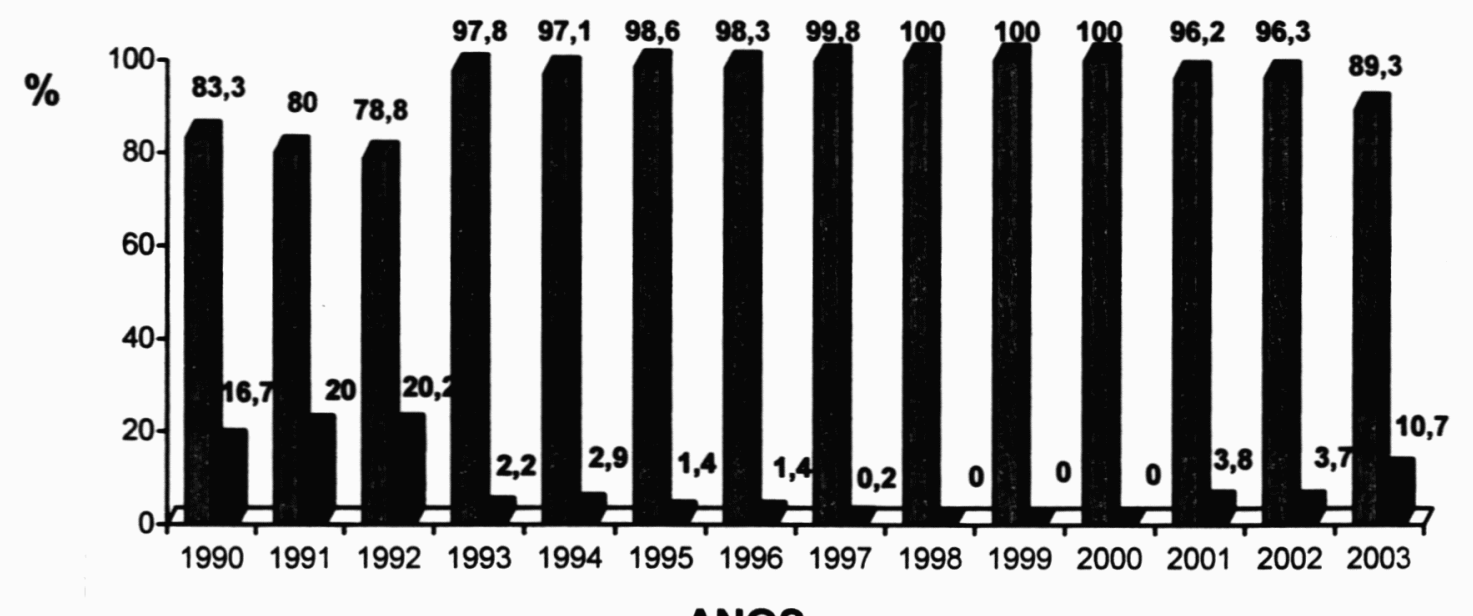

ANOS

Aceitável

D Inaceitável

Fonte: NARVAI 2001; SÃO PAULO 2001, 2002, 2003, 2004. 
A tabela 5.4 apresenta os dados referentes ao consumo de ácido fluorsilicico na Estação de Tratamento de Água Guaraú nos meses de fevereiro a junho no periodo de 1988 a 1993, a média de consumo anual e os limites inferior e superior segundo intervalo de confiança de $95 \%$. Estes dados foram retirados do ANEXO 2, onde há dados do volume de água tratada da ETA Gruaraú de 1974 a 2003 e o consumo de flúor de 1985 a 2003.

Tabela 5.4 - Média de consumo anual de ácido fluorsilicico em toneladas, e

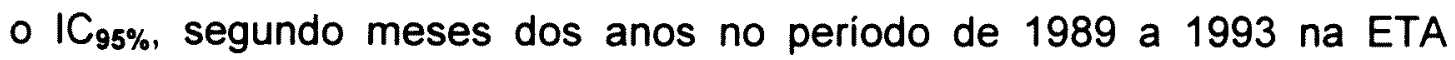
Guaraú, São Paulo.

\begin{tabular}{|c|c|c|c|c|c|c|c|c|}
\hline \multirow[b]{2}{*}{ ANO } & \multicolumn{5}{|c|}{ Meses } & \multirow[b]{2}{*}{ Julho } & \multirow{2}{*}{$\begin{array}{c}\text { Média de } \\
\text { consumo } \\
\text { anual }\end{array}$} & \multirow[b]{2}{*}{ LI - LS } \\
\hline & Fever. & Março & Abril & Maio & Junho & & & \\
\hline 1988 & 231 & 219 & 237 & 231 & 232 & 223 & 230,4 & $218,6-240,2$ \\
\hline 1989 & 236 & 221 & 70 & 246 & 257 & 230 & 231,8 & $203.1-260.4$ \\
\hline 1990 & 234 & 233 & 134 & 148 & 274 & 246 & 238,8 & $211,1 \cdot 265,8$ \\
\hline 1991 & 245 & 183 & 134 & 235 & 266 & 273 & 257,8 & $226,3-289,3$ \\
\hline 1992 & 248 & 40 & 162 & 288 & 303 & 180 & 242,3 & $200,0-285,0$ \\
\hline 1993 & 265 & 307 & 304 & 277 & 282 & 279 & 291,3 & $268.2 \cdot 314.3$ \\
\hline
\end{tabular}

Fonte: Relatório Consumo AFS na ETA Guaraủ 2003. 
Pode-se observar na tabela 5.4 que a população servida por água de abastecimento no município de São Paulo foi beneficiada, entre 1985 e 2003, pelo flúor. Embora tenham ocorrido problemas identificados nas amostras colhidas pelo heterocontrole realizado pela SMS-SP, estes resultados são confirmados através dos dados de flúor na ETA Guaraú pois, nos periodos de 1989 e 1992, ocorreram, em alguns meses do ano, menor adição do ácido fluorsilícico. Este fato ocorreu devido à entressafra da indústria de fertilizantes ocasionando falta do produto no mercado, levando a SABESP a diminuir a colocação de flúor em quantidade necessária no sistema. Após a correção destas falhas, os teores de flúor passaram a estar dentro dos valores aceitáveis em mais de $96 \%$ das amostras no período de 1993 a 2002.

Segundo a SABESP, havia escassez de AFS no mercado no periodo de entressafra da produção de fertilizantes e por isto as empresas fornecedoras não estavam entregando o produto na quantidade necessária para a fluoretação das águas nos niveis recomendados. As empresas fornecedoras, Elekeiros, IAP, Coperbrá e Fosfertil, alegaram que, além dos periodos de entressafra, a produção de fertilizantes havia diminuído no Brasil nos últimos anos devido à crise econômica no Governo Fernando Collor de Melo como também devido à importação de fertilizante a um custo menor (SILVA 1992). 
Segundo NARVAI (2001), devido ao fato das amostras examinadas no heterocontrole estarem acima de $93 \%$ no nivel considerado ótimo, a população esteve efetivamente exposta à ação preventiva do flúor.

\subsection{Custos da fluoretação}

\subsubsection{Entrevista na SABESP}

A Região Metropolitana de São Paulo (RMSP) conta com 8 (oito) sistemas interligados de abastecimento de água sendo que 5 (cinco) destes sistemas são destinados ao abastecimento da cidade de São Paulo.

Todos os sistemas utilizam, como componente quimico para a fluoretação das águas, o ácido fluorsilicico.

$\mathrm{Na}$ Tabela 5.5 estão relacionados os oito sistemas de abastecimento de água da grande São Paulo (os cinco primeiros sistemas abastecem a cidade de São Paulo). O quadro apresenta informações referentes a: vazão de água em metros cúbicos por segundo $\left(\mathrm{m}^{3} / \mathrm{s}\right)$; quantidade de ácido fluorsilícico consumida por dia ( $T / d$ - toneladas/dia), quantidade e tamanho de cada tanque de armazenamento, além da capacidade de estocagem do produto no próprio sistema de abastecimento.

A SABESP tem um depósito central de armazenamento e distribuição dos produtos utilizados no processo de beneficiamento da água. Cada ETA envia para a central de distribuição uma planilha diária contendo o controle de estoque de cada produto, a quantidade recebida dos mesmos 
e quantidade consumida por dia. Com estas informaçōes é realizado o controle logistico da distribuição do estoque regulador para as ETA.

Tabela 5.5 - Estações de Tratamento de Água da Grande São Paulo, segundo vazão de água, consumo diário de ácido fluorsilicico, número de tanques de armazenagem e capacidade de estocagem. São Paulo, 2004.

\begin{tabular}{|c|c|c|c|c|}
\hline ETA & $\begin{array}{c}\text { Vazão da água } \\
\mathrm{m}^{3} / \mathrm{s}\end{array}$ & $\begin{array}{c}\text { AFS } \\
\text { T/d }\end{array}$ & $\begin{array}{l}\text { Tanques arm. } \\
\text { Capacidade tq }\end{array}$ & $\begin{array}{c}\text { Estocagem } \\
\mathrm{m}^{3}\end{array}$ \\
\hline Guaraú - & & & $12 \mathrm{tq}$ & \\
\hline Cantareira & $33 \mathrm{~m}^{3} / \mathrm{s}$ & $10 \mathrm{~T} / \mathrm{d}$ & $50 \mathrm{~m}^{3}$ & $600 \mathrm{~m}^{3}$ \\
\hline Guarapiranga - & & & $12 \mathrm{Tq}$ & \\
\hline Alto da Boa Vista & $14 \mathrm{~m}^{3} / \mathrm{s}$ & $4,45 \mathrm{~T} / \mathrm{d}$ & $25 \mathrm{~m}^{3}$ & $300 \mathrm{~m}^{3}$ \\
\hline \multirow[t]{2}{*}{ AltoTietê } & & & $3 \mathrm{Tq}$ & \\
\hline & $9,5 \mathrm{~m}^{3} / \mathrm{s}$ & $2,75 \mathrm{~T} / \mathrm{d}$ & $50 \mathrm{~m}^{3}$ & $150 \mathrm{~m}^{3}$ \\
\hline \multirow[t]{2}{*}{ Rio Grande } & & & $2 \mathrm{Tq}$ & \\
\hline & $4,5 \mathrm{~m}^{3} / \mathrm{s}$ & $1,10 \mathrm{~T} / \mathrm{d}$ & $30 \mathrm{~m}^{3}$ & $60 \mathrm{~m}^{3}$ \\
\hline \multirow[t]{2}{*}{ Rio claro } & & & $2 \mathrm{Tq}$ & \\
\hline & $4 \mathrm{~m}^{3} / \mathrm{s}$ & $1,00 \mathrm{~T} / \mathrm{d}$ & $50 \mathrm{~m}^{3}$ & $100 \mathrm{~m}^{3}$ \\
\hline \multirow[t]{2}{*}{ Ribeirão da Estiva } & $0,5 \mathrm{~m}^{3} / \mathrm{s}$ & - & - & - \\
\hline & $500 \mathrm{~L} / \mathrm{s}$ & & & \\
\hline \multirow[t]{2}{*}{ Alto Cotia } & $0,9 \mathrm{~m}^{3} / \mathrm{s}$ & - & - & - \\
\hline & $900 \mathrm{~L} / \mathrm{s}$ & & & \\
\hline \multirow[t]{2}{*}{ Baixo Cotia } & $0,6 \mathrm{~m}^{3} / \mathrm{s}$ & - & - & - \\
\hline & $600 \mathrm{~L} / \mathrm{s}$ & & & \\
\hline São Paulo & $65 \mathrm{~m}^{3} / \mathrm{s}$ & $19,30 \mathrm{~T} / \mathrm{d}$ & - & $1.210 \mathrm{~m}^{3}$ \\
\hline
\end{tabular}


A Estação de Tratamento de Água de Guaraú é uma das maiores estações de tratamento de água da América Latina com capacidade de vazão de água de $33 \mathrm{~m}^{3} / \mathrm{s}$. em média diária. A estação consome aproximadamente 10 toneladas de Ácido Fluorsilícico (AFS) por dia e tem capacidade de estocagem cerca de $600 \mathrm{~m}^{3}$. A densidade do produto corresponde a $1,27 \mathrm{~g} / \mathrm{cm}^{3}$ AFS sendo que a concentração $\cong 25 \%$; totalizando um gasto diário de $7,874 \mathrm{~m}^{3}$ representando uma autonomia de trabalho de 76 dias sem reposição dos estoques nesta ETA.

A Estação de Tratamento de Água de Guarapiranga ou Alto da Boa Vista apresenta uma capacidade de vazão de água de $14 \mathrm{~m}^{3} / \mathrm{s}$. Em média a estação consome 126 litros por hora, o que representa 4,45 T/d de AFS e tem capacidade de estocagem de $300 \mathrm{~m}^{3}$ em 12 tanques, divididos em 4 módulos de 3 tanques. $O$ gasto diário é de $3,504 \mathrm{~m}^{3}$ por dia representando uma autonomia de trabalho de 86 dias sem reposiçăo dos estoques nesta ETA.

A Estação de Tratamento de Água do Alto Tietê apresenta uma capacidade de vazão de água de $9,5 \mathrm{~m}^{3} / \mathrm{s}$. em média. A estação consome 90 litros por hora o que representa $2,74 \mathrm{~T} / \mathrm{d}$ de AFS e tem capacidade de estocagem de $150 \mathrm{~m}^{3}$ em 3 tanques. $O$ gasto diário é de $2,158 \mathrm{~m}^{3}$ por dia representando uma autonomia de trabalho de 70 dias sem reposição dos estoques nesta ETA.

A Estação de Tratamento de Água do Rio Grande apresenta em média uma capacidade de vazão de água de $4,5 \mathrm{~m}^{3} / \mathrm{s}$. A estação 
consome 36 litros por hora o que representa $1,10 \mathrm{~T} / \mathrm{d}$ de AFS e tem capacidade de estocagem de $60 \mathrm{~m}^{3}$ em 2 tanques. $O$ gasto diário é de 0,864 $\mathrm{m}^{3}$ por dia, o que representa uma autonomia de trabalho de 70 dias sem reposição dos estoques nesta ETA.

A Estação de Tratamento de Água do Rio Claro apresenta uma capacidade de vazão de água de $4,0 \mathrm{~m}^{3} / \mathrm{s}$. Em média, a estação consome 36 litros por hora o que representa 1,00 T/d de AFS e tem capacidade de estocagem de $50 \mathrm{~m}^{3}$ em 2 tanques. O gasto diário é de $0,787 \mathrm{~m}^{3}$ por dia representando uma autonomia de trabalho de 127 dias sem reposição dos estoques. A ETA do Rio Claro abastece apenas uma pequena parte da cidade de São Paulo e é abastecida pela interligação dos sistemas.

$\mathrm{Na}$ cidade de Săo Paulo consome-se, por dia aproximadamente em média, 19,3 toneladas de do ácido fluorsilícico $\left(\mathrm{H}_{2} \mathrm{SiF}_{6}\right)$ sendo que, segundo informaçōes dos relatórios de controle das estações de tratamento de água, a quantidade de flúor natural vinda dos rios e mananciais que abastece as ETA é cerca de 0,1 ppm de flúor, tornando-se necessária a adição de 0,6 ppm para se obter uma concentração final ideal de 0,7 ppm de flúor na água.

A adição do AFS na água de abastecimento é realizada no final do processo, quando a água já está tratada, clorada e com o pH corrigido. A fluoretação das águas é realizada através de um sistema de bombas dosadoras que têm um mecanismo digital de controle interligado com os sinais de vazão da rede. Assim, quando diminui o fluxo de vazão da água no 
sistema, a bomba dosadora diminui a quantidade do produto adicionado à água, mantendo constante a dosagem correta do flúor.

O controle de dosagem de todos os produtos químicos é realizado em um laboratório dentro da ETA com intervalos de hora em hora durante todo o dia. A análise do flúor é feita através de um sistema digital com eletrodos de íns seletivos. Este método de análise é específico e preciso na aferição da dosagem. Esta metodologia utilizada é recomendada e preconizada pela "Standard Methods" (APHA, 1985). Os dados referem-se ao "Boletim diário de controle operacional - Laboratorial" realizado na ETA Guaraú. No relatório constam as mediçōes realizadas de hora em hora de todos os produtos químicos, inclusive o flúor; o valor máximo e mínimo verificado e a média do dia, além do nome do técnico responsável pelos testes.

Além deste controle na ETA, a SABESP realiza um controle de contra prova diariamente em toda as estaçōes. As amostras coletadas são enviadas para um laboratório central onde são realizados os testes de Cloro, $\mathrm{pH}$, cor, turbidez, presença de metais como ferro, manganês e aluminio, teste bacteriológico e a quantidade de ín flúor presente. Os dados são apresentados com as médias das amostras coletadas, os limites mínimos e máximos encontrados e seu desvio padrão. A partir destes dados e com cada um dos resultados da amostra, é realizada a curva "t de student", obtendo assim a probabilidade de atendimento aos padrões. Todos os resultados são multiplicados entre si e o produto se aplica a raiz à nona 
obtendo índice de performace (IP). Este valor é emitido por um relatório mensal para cada ETA. Em agosto de 2002 e outubro de 2002 respectivamente, o valor médio encontrado na ETA Guaraú para o ácido fluorsilícico foi $0,70 \mathrm{ppm}$ e $0,71 \mathrm{ppm}$ com probabilidade de atendimento aos padrões de 99,9 e 99,3 respectivamente. O IP correspondente a estes meses foi de 99,9. Estes resultados observados são enviados para a Secretaria Municipal de Saúde.

A ETA Guaraú também possui um analisador contínuo de flúor digital (on-line). Este aparelho faz a medição automática e contínua, alterando os dados de acordo com a vazão e possibilitando ao operador verificar no visor qualquer alteração do flúor no sistema. O operador também realiza o teste no laboratório através dos eletrodos. Este aparelho, além de realizar a medição continua, também controla a dosagem de flúor na bomba dosadora.

Estes funcionários do laboratório da SABESP trabalham 36 horas semanais no regime de turnos e o salário médio é de $R \$ 1.500,00$ (não incluindo os benefícios). Há também um rodizio entre funcionários por todas as áreas de trabalho da ETA para que estes tenham conhecimentos sobre as etapas de tratamento de água bem como também sobre as áreas de trabalho da Estação de Tratamento, ocorrendo treinamento interno para os operadores. O tempo médio gasto pelos técnicos da ETA para a análise do flúor é de 15 minutos. 
A ETA Guaraú produz um relatório mensal de despesas de gastos com produtos químicos (Sulfato de alumínio, Cal virgem, Cloro liquido, Ácido fluorsilícico, Polieletrólito, Cloreto férrico e Sulfato férrico) e outros gastos (gastos com pessoal, energia elétrica, compras internas e transporte), tendo como resultado final o custo total da água aduzida, o total de água tratada por mês e o custo final de $1.000 \mathrm{~m}^{3}$ de água tratada na ETA.

A compra do AFS se processa por meio de licitação pública, ocorrendo anualmente. A compra é centralizada pela SABESP para toda as ETA e o produto é fornecido por indústrias de fertilizantes localizadas no municipio de Cubatão. Há duas indústrias responsáveis pelo fornecimento do AFS, a Fosfertil (Empresa do Grupo Ultra Fértil) e a Copebrás.

Desde a implantação do sistema de fluoretação, nenhum dos tanques de armazenagem ou bomba dosadora do ácido fluorsilícico foram trocados, passando por manutenção preventiva periodicamente e manutenção reparadora quando necessário. Como o sistema foi implantado há mais de 17 anos, o custo de instalação inicial dos equipamentos já se diluiu ao longo dos anos.

Outras despesas como compra de equipamentos, tanques de armazenagem, bombas dosadoras de flúor, medidores digitais, despesas com treinamento e atualização dos funcionários, despesas de laboratórios e manutenção do sistema não puderam ser dissociados dos gastos totais de toda a rede de abastecimento. 
A tabela 5.6 apresenta o total de consumo de ácido fluorsilícico (AFS), o volume de água consumida em metros cúbicos $\left(\mathrm{m}^{3}\right)$, a relação de AFS por $1.000 \mathrm{~m}^{3}$ de água nos anos de 1985 a 2003, a média de consumo mensal, o desvio padrão e o $I_{95 \%}$, na Estação de Tratamento de Água Guaraú.

A tabela 5.7 apresenta os custos anuais de tratamento de água na ETA Guaraú no período de 1998 a 2003, o volume total de água tratada e a relação de custo em $R \$$ para cada $1.000 \mathrm{~m}^{3}$ de água tratada. A composição final do custo está estratificada segundo: Ácido Fluorsilícico (consumo em toneladas, o custo do flúor o custo por tonelada); Produtos Químicos (sulfato de alumínio, cal virgem, cloro líquido, polieletrólito, cloreto férrico e sulfato férrico); Recursos Humanos (custos com salários e encargos trabalhistas); Energia Elétrica (kWh e o custo); Transporte e outras despesas (despesas internas da ETA). Também é apresentada a relação percentual de cada componente do custo em relação ao custo total do tratamento de água. 
Tabela 5.6 - Consumo anual de ácido fluorsilícico, consumo de água $\left(\mathrm{m}^{3}\right)$, consumo total de ácido fluorsilicico (AFS) por volume água $\left(\mathrm{Kg} / 1000 \mathrm{~m}^{3}\right)$, média de consumo de ácido fluorsilícico, desvio padrão e o $\mathrm{IC}_{95 \%}$, na ETA Guaraú no período de 1985 a 2003, São Paulo.

\begin{tabular}{|c|c|c|c|c|c|c|}
\hline ANO & $\begin{array}{l}\text { AFS } \\
\text { (Ton.) }\end{array}$ & $\begin{array}{l}\text { Volume } \\
\text { água }\left(\mathrm{m}^{3}\right)\end{array}$ & $\begin{array}{c}\text { AFS } \\
\left(\mathrm{Kg} / 1000 \mathrm{~m}^{3}\right)\end{array}$ & $\begin{array}{c}\text { Média } \\
\text { consumo } \\
\text { Mensal (AFS) }\end{array}$ & $\begin{array}{l}\text { Desvio Padräo } \\
\text { do consumo } \\
\text { (ATS) }\end{array}$ & $\mathcal{L} I-\mathcal{L} S$ \\
\hline $1985^{\star}$ & 360 & 634.106 .706 & 0,57 & 180,0 & 1,0 & $178,6-181,4$ \\
\hline 1986 & 2.323 & 728.049 .783 & 3,19 & 193,6 & 19,7 & $182,4-204,7$ \\
\hline 1987 & 2.737 & 829.085 .938 & 3,30 & 228,1 & 8,4 & $223,3-232,8$ \\
\hline 1988 & 2.765 & 871.203 .015 & 3,17 & 230,4 & 13,8 & $222,6-238,2$ \\
\hline 1989 & 2.781 & 895.180 .016 & 3,11 & 231,8 & 50,6 & $203,1-260,4$ \\
\hline 1990 & 2.865 & 917.960 .822 & 3,12 & 238,8 & 47,9 & $211,1-265,8$ \\
\hline 1991 & 3.093 & 945.452 .654 & 3,27 & 257,8 & 55,6 & $226,3-289,3$ \\
\hline 1992 & 2.908 & 959.560 .278 & 3,03 & 242,3 & 75,4 & $200,0-285,0$ \\
\hline 1993 & 3.495 & 1.000 .999 .412 & 3,49 & 291,3 & 23,0 & $278,2-304,3$ \\
\hline 1994 & 3.494 & 1.038 .264 .615 & 3,37 & 291,2 & 22,8 & $278,3-304,1$ \\
\hline 1995 & 3.745 & 1.057.707.271 & 3,54 & 312,1 & 35,0 & $292,3-331,8$ \\
\hline 1996 & 3.743 & 1.053 .538 .830 & 3,55 & 311,9 & 19,6 & $300,8-323,0$ \\
\hline 1997 & 3.685 & 1.047 .106 .323 & 3,52 & 307,1 & 40,2 & $284,3-329,8$ \\
\hline 1998 & 3.502 & 1.037 .797 .978 & 3,37 & 291,8 & 27,6 & $276,2-307,5$ \\
\hline 1999 & 3.734 & 1.045 .568 .497 & 3,57 & 311,2 & 27,4 & $295,6-326,7$ \\
\hline 2000 & 3.703 & 1.019 .521 .640 & 3,63 & 308,3 & 31,3 & $290,6-326,1$ \\
\hline 2001 & 3.658 & 958.124 .617 & 3,82 & 304,8 & 29,7 & $288,0-321,6$ \\
\hline 2002 & 3.670 & 1.005 .514 .451 & 3,65 & 305,8 & 19,7 & $294,7-317,0$ \\
\hline 2003 & 3.664 & 996.385 .844 & 3,68 & 305,3 & 34,0 & $298,3-312,2$ \\
\hline
\end{tabular}

Fonte: Relatório Consumo AFS na ETA Guaraú 1985-2003 .

* 1985 meses de novembro e dezembro. 
Tabela 5.7 - Custo anual de tratamento de água, segundo componentes dos custos, ácido fluorsilícico, produtos químicos, recursos humanos, energia elétrica, transporte e outras despesas, e o volume total de água tratada nos anos de 1998 a 2003 na ETA Guaraú, São Paulo.

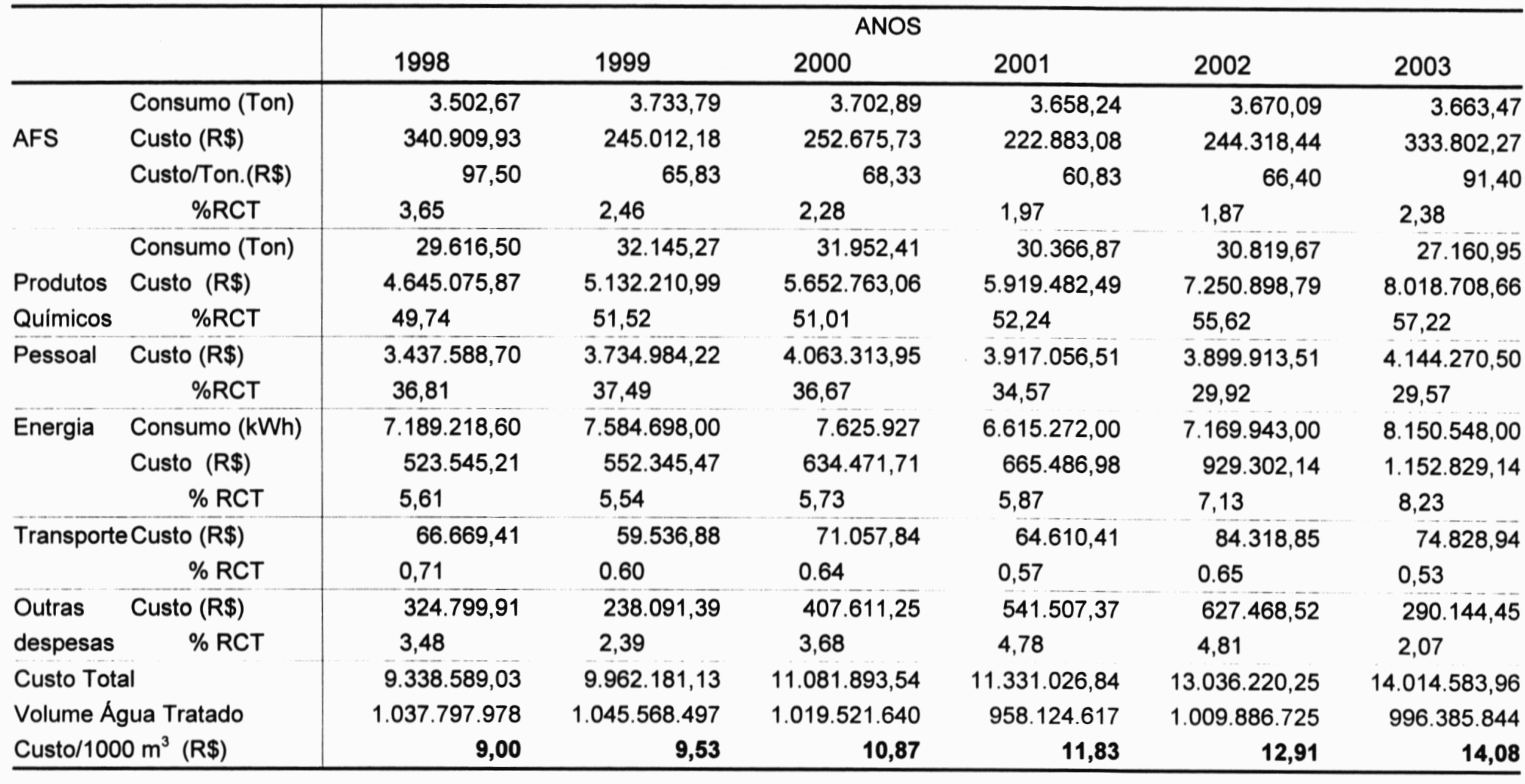




\subsubsection{Custos com fornecedores}

Como observado na tabela 5.7, o custo do AFS comprado pela SABESP no período de 1998 a 2003 obteve uma variação média por ano de R\$ 60,83 a R\$ 97,50 por tonelada. Segundo o Manual da OPS - OMS, nos EUA, na década de 70 , o custo do AFS a uma concentraçăo de $20 \%$ era de US $\$ 40,00$ a tonelada (OPS-OMS, 1975). No ano de 1986, nos EUA, o custo do AFS variava de US $\$ 30,00$ a US $\$ 150,00$ por tonelada (CDC, 1991), sendo que o custo do AFS poderia ser duplicado ou até triplicado algumas vezes devido ao custo de transporte do produto quimico do fornecedor até a estação de tratamento. $O$ custo poderia ter também uma redução devido ao volume adquirido pois, quanto maior a quantidade comprada, menor o custo do produto e do transporte, embora sejam necessários um local adequado e tanques próprios para o armazenamento (CDC, 1991).

Na composição dos custos de fluoretação também deve-se incluir os custos fixos de instalação do sistema (WHITE et al 1989), o custo dos tanques de armazenamento do ácido fluorsilicico, que varia de R\$ $2.000,00$ para tanques de $50 \mathrm{~m}^{3}$ de AFS, R\$ $1.200,00$ para $30 \mathrm{~m}^{3}$, $R \$ 1.000,00$ para tanque de $25 \mathrm{~m}^{3}$ de AFS e R $\$ 400,00$ para tanque de $10 \mathrm{~m}^{3}$ e para tanque de $100 \mathrm{Kg}$ de AFS, US $\$ 60,00$ (OPS-OMS 1975). A bomba dosadora varia de US $\$ 400,00$ a US $\$ 600,00$ (OPS-OMS 1975), e de US $\$ 1.200,00$ a US $\$ 4.000,00$ (CDC 1991). O custo da bomba dosadora com controle de 4 a $20 \mathrm{~mA}$ e com uma vazão de AFS de 3,6 Lhora tem um custo de R\$4.000,00 (DIGIMED 2003) e a bomba dosadora automática com 
micro processador com motor de $60 \mathrm{~Hz}$ e 40 bar e vazão de 1,3 a 2 Lhora, apresenta custo médio de $\mathbf{R} \$ 2.200,00$ (SABESP 2003).

O custo de controle do nivel de flúor também é importante no processo, tanto o controle do flúor natural que chega na água para ser tratada como a concentração de flúor após o tratamento, que deve estar no nivel ideal, ou seja, $0.7 \mathrm{mg}$ de flúor por litro de água. Há três modelos de medidores de flúor: o medidor de flúor colorimétrico portátil, da empresa DIGIMED - modelo DM C4, que tem um custo variando entre $R \$ 2.000,00 \mathrm{e}$ $\mathrm{R} \$ 3.000,00$; o medidor de flúor de bancada com eletrodos da empresa DIGIMED - modelo DM-21 + DMI-FL + DME-R21, que apresenta um custo de $R \$ 6.345,00$ e, finalmente, o medidor de flúor do tipo on-line que, além de realizar o controle contínuo do nível de flúor, também está ligado com a bomba dosadora, regulando a saída da dosagem de flúor continuamente; o medidor da empresa DIGIMED - modelo AI-FL3 tem um custo de R\$24.700,00. O medidor cololimétrico apresenta variação de custo entre US\$ 470,00 e US $\$ 795,00$ (OPS-OMS 1975), e de US $\$ 800,00$ a US\$1.000,00 (CDC 1991). Já o medidor de ion-seletivo apresenta custo médio de US\$1.200,00 a US $\$ 3.000,00$ (CDC 1991).

Outro custo no processo de fluoretação refere-se aos eletrodos de íon-sensível para dosagem de fluoreto da empresa DIGIMED - modelo $\mathrm{DMI}$ - FL, que têm um custo de $\mathrm{R} \$ 2.000,00$, tendo um tempo de vida útil que varia de 1 a 2 anos conforme o uso. Nos EUA o custo dos eletrodos varia de US $\$ 150,00$ a US $\$ 295,00$ (OPS-OMS 1975) e de US $\$ 400,00$ a 
US\$ 450,00 segundo o CDC (1991), com tempo de utilidade variando de 1 a 3 anos, onde a média geralmente é de 1 ano e seis meses dependendo do uso (CDC 1991). Sendo assim, o custo do eletrodo será incorporado, ano a ano, ao custo final da fluoretação. 


\subsection{Análise de custos}

Para a análise de custos do sistema de fluoretação das águas do município de São Paulo utilizaram-se os dados referentes aos anos de 1998 e 2003 da ETA Guaraú (tabela 5.7), os custos foram atualizados para o ano base de 2003 tendo como índice de correção monetária o IPC/FIPE Índice de Preços ao Consumidos, da Fundação Instituto de Pesquisa Econômica / USP (IPC/FIPE 2004).

A composição dos custos totais foi estratificada segundo, quatro itens: Custo de Capital Inicial de Instalação, Custo dos Produtos Químicos, Custo de Operacionalização do Sistema e o Custo de Controle.

\section{5-1 Custo de Capital Inicial de Instalação}

O Custo de Capital Inicial de Instalação será composto pelos: custos de equipamentos (bombas dosadoras, tanques de armazenamento, equipamentos de controle e testes de dosagem); custos de instalação dos equipamentos e o custo de consultoria técnica. A composição final do Custo de Capital Inicial de Instalação, embora tenham sido desembolsados no momento de implantação do sistema, serão divididos por 20 anos, ou seja, o tempo de vida útil dos equipamentos. Este período de vida útil dos equipamentos varia entre 10 anos segundo NIESSEN e DOUGLASS (1984), 15 anos segundo RINGELBERG et al (1992), GARCIA (1989) e WRIGHT (2001), 20 anos segundo NELSON e SWINT (1976) e MANAU et al (1987) ou 25 anos segundo CARR et al (1980). Segundo dados da Sabesp, os equipamentos instalados apresentam 18 anos de uso e estão em ótimo 
estado de conservação devido à realização de manutenção preventiva rotineira e manutenção corretiva quando necessário.

Os Custos de Instalação dos Equipamentos representam cerca de $80 \%$ a $90 \%$ dos custos do equipamento, segundo o $\operatorname{CDC}(1991,1995)$. Sendo assim, utilizaremos como base para o cálculo do custo de instalação a porcentagem de $85 \%$ do valor dos equipamentos.

Os Custos de Consultoria Técnica representam $15 \%$ dos custos de capital inicial de instalação segundo o $\operatorname{CDC}(1991,1995)$ e, portanto, após o resultado final dos custos, estes serão acrescidos de $15 \%$ referente à consultoria técnica.

Devido à grande instabilidade econômica que se abateu no pais nas duas últimas décadas, com mudanças da moeda, variação constante do cambio em relação ao dólar e períodos de inflação anual com valores muito elevados, optou-se por utilizar os valores dos equipamentos praticados no mercado no momento atual, ou seja, no ano de 2003.

\section{Equipamentos:}

- Bombas dosadoras a $\mathrm{R} \$ 4.000,00$ cada. São necessárias duas bombas por ponto de fluoretação pois, segundo BUENDIA (1996), enquanto uma bomba está em uso, a outra fica na reserva, invertendo-se para manutenção e evitando, assim, a não fluoretação do sistema em caso de 
manutenção. Há cinco ETA que abastecem a cidade de São Paulo, totalizando o custo das bombas em $R \$ 40.000,00$.

- Tanques de armazenamento do ácido fluorsilicico: a Sabesp possui nas 5 ETA três tamanhos diferentes de tanques, com volumes de armazenamento diferentes. $O$ tanque de $50 \mathrm{~m}^{3}$ com custo de $\mathrm{R} \$ 2.000,00$ cada (a Sabesp dispõe de 17 tanques de $50 \mathrm{~m}^{3}$ totalizando $\mathrm{R} \$ 34.000,00$ ). $\mathrm{O}$ tanque de $25 \mathrm{~m}^{3}$ com custo de R\$1.000,00, (a Sabesp conta com 12 tanques de $25 \mathrm{~m}^{3}$ totalizando $R \$ 12.000,00$ ) e o tanque de $30 \mathrm{~m}^{3}$ cujo custo é de $\mathrm{R} \$ 1.200 .00$ (a Sabesp tem 3 tanques de $30 \mathrm{~m}^{3}$ totalizando $\mathrm{R} \$ 3.600,00$ ). O custo total dos tanques de armazenamento de flúor para a cidade de São Paulo é de $R \$ 49.600,00$.

Custos de instalação dos equipamentos: representam $85 \%$ dos custos de dos equipamentos ( $R \$ 89.600,00$ ) ou seja, $R \$ 76.160,00$.

Equipamentos de controle dos níveis de flúor realizados nos laboratórios das ETA: o medidor de bancada de eletrodos com ion seletivo de flúor com custo de $R \$ 6.345,00$, (para as 5 ETA o custo total é de R\$ $31.725,00)$. O medidor de flúor do tipo On-line cujo custo é de R\$ 24.700,00 (apenas na ETA Guaraú). O custo total dos equipamentos de testes e controle é de R\$ $56.425,00$.

Custo da Consultoria Técnica: representa $15 \%$ do custo de capital inicial de instalação ( $R \$ 222.185,00)$, ou seja, $R \$ 33.327,75$. 
Assim, o Custo de Capital Inicial de Instalação corresponde a R\$ $255.512,75$, (com todos os itens incluídos), onde este valor é fracionado em 20 anos, representando um custo de R\$ $12.775,64$ por ano no sistema de abastecimento.

Tabela 5.8 - Custos de Capital Inicial de Instalação, segundo componentes de custos para o sistema de tratamento de água do município de São Paulo, 2004.

\begin{tabular}{|c|c|c|c|c|c|c|}
\hline $\begin{array}{c}\text { Bombas } \\
\text { dosadoras }\end{array}$ & $\begin{array}{l}\text { Tanque de } \\
\text { armazenam. }\end{array}$ & $\begin{array}{l}\text { Custos de } \\
\text { instalacklo }\end{array}$ & $\begin{array}{l}\text { Equipamentos } \\
\text { de controle }\end{array}$ & $\begin{array}{l}\text { Consultoria } \\
\text { tecnica }\end{array}$ & $\begin{array}{l}\text { Custo Capital } \\
\text { Inicial Inst. }\end{array}$ & $\begin{array}{l}\text { Fracionado } \\
\text { por } 20 \text { anos }\end{array}$ \\
\hline $\begin{array}{c}\text { RS } \\
40.000,00\end{array}$ & $\begin{array}{c}\text { RS } \\
49.600,00\end{array}$ & $\begin{array}{c}\text { RS } \\
76.160,00\end{array}$ & $\begin{array}{c}\mathrm{RS} \\
56.425,00\end{array}$ & $\begin{array}{c}\text { RS } \\
\mathbf{3 3 . 3 2 7 . 7 5}\end{array}$ & $\begin{array}{c}\text { RS } \\
255.512,75\end{array}$ & $\begin{array}{c}\text { RS } \\
12.775,64\end{array}$ \\
\hline
\end{tabular}

\section{5-2 Custo do Produto Químico}

A água que chega nas ETA para tratamento apresenta $0,1 \mathrm{ppm}$ de flúor natural e, portanto, é necessária a adição de mais $0,6 p p m$ para atingir o nivel ideal recomendado. Como a ETA Guaraú é responsável por aproximadamente metade do abastecimento de água da cidade de São Paulo, os valores referentes ao consumo e ao custo de AFS utilizado na ETA Guaraú foram dobrados, visando obter uma dimensão mais próxima da real dos custos de produtos químicos utilizados na cidade de São Paulo, nos anos de 1998 a 2003. Os dados da tabela 5.7 são referentes a ETA Guaraú e os dados da tabela 5.9 são representativos dos custos do Ácido Fluorsilícico utilizados na cidade de São Paulo no intervalo entre os anos de 1998 a 2003, atualizados pelo IPC/FIPE (2004). 
Tabela 5.9 - Custos do Ácido Fluorsilicico utilizado para fluoretação do sistema de tratamento de água do município de São Paulo, 2004.

\begin{tabular}{lcccccc}
\hline & \multicolumn{7}{c}{ Anos } \\
& 1998 & 1999 & 2000 & 2001 & 2002 & 2003 \\
\hline $\begin{array}{l}\text { Custo do } \\
\text { AFS (RS) }\end{array}$ & $681.819,86$ & $637.374,69$ & $613.648,28$ & $521.769,29$ & $537.109,64$ & $667.604,54$ \\
\hline
\end{tabular}

O custo por tonelada de AFS de 1998 a 2003 teve uma variação de preço de $\mathrm{R} \$ \mathbf{9 7 , 5 0}$ a $\mathrm{R} \$ \mathbf{6 0 , 6 3}$ ton-AFS. Em dezembro de 2003, o custo da tonelada do AFS para a Sabesp foi de R $\$ 100.00$ a tonelada, ou seja, $\mathrm{R} \$ 0,01 / \mathrm{Kg}_{\mathrm{AFs}}$. Este valor já inclui o transporte e o frete das empresas situadas na cidade de Cubatão até as respectivas Estações de Tratamento. Segundo o CDC (1991), o custo do transporte é o que mais encarece o produto químico, principalmente se o fornecedor for distante da estação de tratamento, chegando a dobrar ou, algumas vezes, triplicar o valor do produto químico AFS.

\section{5-3 Custo de Operacionalização do Sistema}

Os componentes que perfazem o Custo de Operacionalização do Sistema são: o custo de depreciação e de manutenção dos equipamentos, o custo da energia elétrica e o custo com recursos humanos.

O custo de depreciação e manutenção dos equipamentos representa cerca de $10 \%$ do valor total do Custo de Capital Inicial de Instalação e é distribuido pelo tempo de vida útil dos equipamentos (WHITE 
et al 1989). Para RINGELBERG et al (1992), o custo de depreciação varia de $2 \%$ a $4 \%$.

WHITE et al (1987) referiram-se ao custo de energia elétrica, e afirmaram que, apesar de geralmente ser difícil o cálculo e inclusão, não é apropriado excluir estes custos e estes podem ter o valor estimado, podendo ser calculados a partir dos custos da estação de tratamento de água.

Assim, visando o cálculo dos custos de energia elétrica para a fluoretação, foi utilizado a porcentagem dos gastos de energia elétrica de toda a rede de abastecimento, que apresentaram variação de $5 \%$ a $8 \%$, esta foi usada como base e aplicada sobre o custo do AFS utilizado na Estação de tratamento no período da 1998 a 2003.

Os custos com recursos humanos são estratificados segundo custos de controle operacional do sistema de fluoretação e custos de controle e testes laboratoriais. O controle operacional do sistema de fluoretação é realizado com os mesmos recursos humanos de operação do sistema de tratamento de água não onerando, assim, o custo final. $O$ controle laboratorial é exercido por pessoal técnico especializado que realiza, além do controle do flúor, outros testes químicos para o controle da água.

O controle laboratorial dos teores de flúor é realizado nos laboratórios da Estação de tratamento, de hora em hora, durante 24 horas por dia. O teste de concentração do flúor dura 10 minutos e, durante um dia, representa 4 horas de trabalho e, durante 7 dias por semana, corresponde a 
28 horas semanais de trabalho. Um funcionário técnico que trabalha nesta função recebe um salário de $R \$ 1.500,00$ mensais mais $13^{\circ}$ salário; R\$ 675,00 de encargos trabalhistas e R\$ 450,00 de $1 / 3$ de férias, totalizando $\mathrm{R} \$ 28.725,00$ por ponto de fluoretação. Ao ano o custo com recursos humanos, para as cinco ETA, na cidade de São Paulo, está estimado em $R \$ 143.625,00$.

A tabela 5.10 apresenta os custos de operacionalização do sistema, estratificado segundo os custos de depreciação e manutenção dos equipamentos, o custo de energia elétrica e recursos humanos para fluoretação do Sistema de Tratamento de Água do município de São Paulo.

Tabela 5.10 - Custos de operacionalização do sistema, segundo os Custos de depreciação e manutenção dos equipamentos, incluindo energia elétrica e recursos humanos para fluoretação do sistema de tratamento de água do município de São Paulo, no período 1998-2003.

\begin{tabular}{|c|c|c|c|c|c|c|c|}
\hline \multirow{2}{*}{\multicolumn{2}{|c|}{$\begin{array}{l}\text { Custos de } \\
\text { operacionalizaçăo } \\
\text { do sistema }\end{array}$}} & \multicolumn{6}{|c|}{ ANOS } \\
\hline & & 1998 & 1999 & 2000 & 2001 & 2002 & 2003 \\
\hline \multicolumn{2}{|c|}{$\begin{array}{c}\text { depreciaçăo e } \\
\text { manutençáo dos } \\
\text { equipamentos (R\$) }\end{array}$} & $1.277,56$ & $1.277,56$ & $1.277,56$ & $1.277,56$ & $1.277,56$ & $1.277,56$ \\
\hline \multirow{2}{*}{$\begin{array}{l}\text { Energia } \\
\text { Elétrica }\end{array}$} & $\%$ & 5,16 & 5,54 & 5,73 & 5,87 & 7,13 & 8,23 \\
\hline & R\$ & $35.181,90$ & 35310,56 & $35.162,05$ & $30.627,86$ & $38.295,92$ & $54.943,85$ \\
\hline \multicolumn{2}{|c|}{$\begin{array}{c}\text { Recursos } \\
\text { Humanos (R\$) }\end{array}$} & $143.625,00$ & $143.625,00$ & $143.625,00$ & $143.625,00$ & $143.625,00$ & $143.625,00$ \\
\hline \multicolumn{2}{|c|}{$\begin{array}{l}\text { Total dos } \\
\text { Custos de } \\
\text { operacionalizaçăo } \\
\text { do sistema }\end{array}$} & $\begin{array}{c}R \$ \\
180.084,46\end{array}$ & $\begin{array}{c}\text { RS } \\
180.213,12\end{array}$ & $\begin{array}{c}\text { RS } \\
180.064,61\end{array}$ & $\begin{array}{c}\text { R\$ } \\
175.530,42\end{array}$ & $\begin{array}{c}R S \\
183.198,46\end{array}$ & $\begin{array}{c}\text { RS } \\
199.846,41\end{array}$ \\
\hline
\end{tabular}




\section{5-4 Custo de Controle}

O custo de controle do nivel ideal de flúor na água de abastecimento tem um custo fixo que é representado pelo equipamento de mediçăo e controle - cujo valor já foi acrescido ao Custo de Capital Inicial de Instalação - e um custo continuo, que é representado pelos eletrodos de ín-seletivo para a dosagem de fluoreto, que têm em média 1,5 anos de vida útil CDC (1991), e que custa de R\$2.000,00. Segundo o CDC (1991), o custo do eletrodo varia de U\$ 400,00 a U $\$ 450,00$.

Sendo assim, ficou estabelecido que a troca de um eletrodo será realizada a cada um ano e seis meses por estação de tratamento, (cinco estações de tratamento), correspondendo a um custo de $R \$ 7.500,00$ por ano para o sistema.

5.5-5 Custos da fluoretação da água no sistema de tratamento de água no município de São Paulo

A tabela 5.11 apresenta os dados do custo do sistema de fluoretação no município de São Paulo, nos períodos de 1998-2003, atualizados pelo IPC/FIPE (2004) tendo como ano base 2003.

É importante destacar que os custos foram estratificados segundo custos de capital inicial de instalação, custo do AFS, custo de operacionalização (manutençăo, energia elétrica e recursos humanos), custos de controle e os custos totais como também, o volume de água tratada consumida pela cidade. A projeção do crescimento da população da 
cidade de São Paulo, segundo uma taxa de crescimento de 0,91, de 19912000 (SEADE 2003), foi também utilizada para os anos de 2001 a 2003. Foi utilizando o "Método de crescimento médio anual" através da taxa de progressão de crescimento aritmético proposto por LAURENTI et al (1987). Calculou-se o custo per capita / ano em relação ao real e ao dólar (cotação média do dólar no ano em relação ao real), obtendo-se o custo da fluoretação per capita / ano em dólar.

Fórmula para o cálculo do custo de fluoretação per capita / ano

$$
\text { Custo Fluoretação }=\frac{\mathrm{CCll}+\mathrm{CPQ}+\mathrm{COS}+\mathrm{CC}}{\text { População da cidade no ano }}
$$

* CCII = Custo de Capital Inicial de Instalaçăo;

* $\mathrm{CPQ}=$ Custo de Produto Quimico;

* $\operatorname{COS}=$ Custo de Operacionalização do Sistema;

${ }^{\star} \mathrm{CC}=$ Custo de Controle. 
Tabela 5.11 - Composição dos custos de fluoretação das águas de abastecimento público no município de São Paulo no período de 1998 a 2003.

\begin{tabular}{|c|c|c|c|c|c|c|c|c|c|c|c|c|}
\hline \multicolumn{13}{|c|}{ Anos } \\
\hline & \multicolumn{2}{|c|}{1998} & \multicolumn{2}{|c|}{1999} & \multicolumn{2}{|c|}{2000} & \multicolumn{2}{|c|}{2001} & \multicolumn{2}{|c|}{2002} & \multicolumn{2}{|c|}{2003} \\
\hline $\begin{array}{l}\text { Custo de Capital } \\
\text { Inicial de Inst. (R\$) }\end{array}$ & \multicolumn{2}{|c|}{$12.775,64$} & \multicolumn{2}{|c|}{$12.775,64$} & \multicolumn{2}{|c|}{$12.775,64$} & \multicolumn{2}{|c|}{$12.775,64$} & \multicolumn{2}{|c|}{$12.775,64$} & \multicolumn{2}{|c|}{$12.775,64$} \\
\hline$\%$ Custos Custo/pes. & $1,45 \%$ & $\mathrm{R} \$ 0,001$ & $1,52 \%$ & $\mathrm{R} \$ 0,001$ & $1.57 \%$ & $\mathrm{R} \$ 0,001$ & $1,78 \%$ & $\mathrm{R} \$ 0,001$ & $1.73 \%$ & $\mathrm{R} \$ 0,001$ & $1,44 \%$ & $\mathrm{R} \$ 0,001$ \\
\hline Custo químico (R\$) & \multicolumn{2}{|c|}{$681.819,86$} & \multicolumn{2}{|c|}{$637.374,69$} & \multicolumn{2}{|c|}{$613.648,28$} & \multicolumn{2}{|c|}{$521.769,29$} & \multicolumn{2}{|c|}{$537.109,64$} & \multicolumn{2}{|c|}{$667.604,54$} \\
\hline$\%$ Custos Custo/pes. & $77,29 \%$ & $\mathrm{R} \$ 0,067$ & $76,07 \%$ & $\mathrm{R} \$ 0,062$ & $75,39 \%$ & $\mathrm{R} \$ 0,059$ & $72,71 \%$ & $\mathrm{R} \$ 0,050$ & $72,53 \%$ & $\mathrm{R} \$ 0,051$ & $75,20 \%$ & $\mathrm{R} \$ 0,063$ \\
\hline Custos de op. Sist.(R\$) & \multicolumn{2}{|c|}{$180.084,46$} & \multicolumn{2}{|c|}{$180.213,12$} & \multicolumn{2}{|c|}{$180.064,61$} & \multicolumn{2}{|c|}{$175.530,42$} & \multicolumn{2}{|c|}{$183.198,48$} & \multicolumn{2}{|c|}{$199.846,41$} \\
\hline$\%$ Custos Custo/pes. & $20,41 \%$ & $\mathrm{R} \$ 0,018$ & $21,51 \%$ & $\mathrm{R} \$ 0,017$ & $22,12 \%$ & $\mathrm{R} \$ 0,017$ & $24,46 \%$ & $\mathrm{R} \$ 0,017$ & $24,74 \%$ & $\mathrm{R} \$ 0,017$ & $22,51 \%$ & $\mathrm{R} \$ 0,019$ \\
\hline Custo de Controle (R\$) & \multicolumn{2}{|c|}{$7.500,00$} & \multicolumn{2}{|c|}{$7.500,00$} & \multicolumn{2}{|c|}{$7.500,00$} & \multicolumn{2}{|c|}{$7.500,00$} & \multicolumn{2}{|c|}{$7.500,00$} & \multicolumn{2}{|c|}{$7.500,00$} \\
\hline$\%$ Custos Custo/pes. & $0,85 \%$ & $\mathrm{R} \$ 0,001$ & $0,90 \%$ & $\mathrm{R} \$ 0,001$ & $0,92 \%$ & $\mathrm{R} \$ 0,001$ & $1,05 \%$ & $\mathrm{R} \$ 0,001$ & $1,01 \%$ & $\mathrm{R} \$ 0,001$ & $0,84 \%$ & $\mathrm{R} \$ 0,001$ \\
\hline Custo Total (RS) & 882. & 79,96 & 837. & 363,45 & 813. & 88.43 & 717. & 75,35 & 740.5 & 83,76 & 887. & 26,59 \\
\hline Vol.de água tratada & 2.075 & 595.956 & 2.091 & 136.994 & 2.039 & 43.280 & 1.916. & 49.234 & 2.019 .9 & 93.450 & 1.992. & 771.688 \\
\hline População & 10.2 & 1.378 & 10.3 & 14.977 & 10.3 & 8.576 & 10.48 & 2.175 & 10.56 & 5.774 & 10.6 & 9.373 \\
\hline $\begin{array}{l}\text { Custo/população } \\
\text { Pessoa/ ano (RS) }\end{array}$ & & 086 & & 081 & & 978 & & 68 & $\mathbf{0 , 0}$ & 70 & & 083 \\
\hline $\begin{array}{c}\text { Cotação média ano } \\
\text { US\$ / R\$ }\end{array}$ & US $\$ 1,0$ & / R\$ 1,164 & US\$ 1,0 & / R\$ 1,847 & US\$ 1,0 & / R\$ 1,833 & US\$ 1,00 & $R \$ 2,353$ & US $\$ 1,00$ & $\mathrm{R} \$ 2,998$ & US\$ 1,00 & / R\$ 3,063 \\
\hline $\begin{array}{l}\text { Custo/população } \\
\text { Pessoa/ ano (US\$) }\end{array}$ & & 074 & & 044 & & 43 & & 29 & 0.0 & 23 & & 27 \\
\hline
\end{tabular}


Realizar uma análise de custos em paises cuja economia apresenta-se instável com mudanças de moeda, variação cambial constante e inflação de quase mil porcento em um ano não é tarefa fácil. Por estas razões, foi necessário estabelecer um lastro, ou seja, uma moeda estável para podermos comparar os custos. NIESSEN e DOUGLASS (1984) sugerem como referência monetária $\circ$ dólar e, assim, optou-se neste trabalho, pela utilização do real (R\$) como padrão monetário brasileiro atual e o dólar americano (US\$) como referência.

O sistema de fluoretação das águas de abastecimento da cidade de São Paulo foi implantado em outubro de 1985. Nesta época, estava em vigor como moeda corrente o Cruzeiro ( $\mathrm{Cr} \$)$, que foi substituido pelo Cruzado (Cz\$) pelo decreto Lei $22.283 / 86$ de 27/02/86 e tendo como valor de conversão $(\mathrm{Cr} \$ 1.000,00=\mathrm{Cz} \$ 1,00)$. Em 15/01/89, o Cruzado foi extinto sendo substituido pelo Novo Cruzado (NCz\$) através da Medida Provisória $n^{\circ} 32$ de 15/01/89 e a Lei $n^{\circ} 7.730 / 98$ de 31/01/89 quando novamente cortou-se três zeros $(C z \$ 1.000,00=N C z \$ 1,00)$.

O Novo cruzado vigorou até $15 / 03 / 90$ quando foi substituído pelo Cruzeiro (Cr\$), através da Medida Provisória (MP) nº 168 de 15/03/90 e Lei $n^{\circ} 8024 / 90$ de $12 / 04 / 90$, mantendo-se a paridade entre as moedas ( NCz\$ 1,00 = Cr\$ 1,00). Em 28 de julho de 1993 criou-se uma nova moeda, - Cruzeiro Real (CR\$) através da MP no 336 de 228/07/93 e pela Lei $n^{\circ}$ $8.697 / 93$ de 27/08/93 e, na conversão, perdeu-se novamente três zeros (Cr\$ 1.000,00 $=$ CR\$ 1,00). Em abril de 1994, foi criada a URV (unidade de 
referência de valor) pela MP $n^{\circ} 482$ de 28/04/94 e a lei 8880/94 de 27/05/94 onde a conversão foi de (CR\$ 2.750,00 = 1,00 URV). Em julho de 1994 criou-se o Real (R\$) pela MP n566 de 29/07/94 onde houve paridade com a URV, ou seja $(1,00$ URV $=R \$ 1,00)$ quando o Real também tinha paridade com o dólar ( $R \$ 1,00=$ US\$1,00) e esta nova moeda vigora até os dias de hoje.

Assim sendo, $R \$ 1,00=C R \$ 2.750,00=\operatorname{Cr} \$ 2.750 .000,00=$ NCz $\$ 2.750 .000,00=C z \$ 2.750 .000 .000,00=$ Cr $\$ 2.750 .000 .000 .000,00$ ou seja $R \$ 1,00$ equivaleria a dois trilhões setecentos e cinqüenta bilhões de cruzeiros na época da implantação dos sistema de fluoretação se não levarmos em conta a inflação, e a correção monetária.

Para a realização da estimativa de custos do sistema de fluoretação das águas no municipio de São Paulo no periodo de 1985 2003, são necessárias algumas informaçōes sobre o consumo anual de AFS em toneladas no período. A partir dos dados da tabela 5.7 obtém-se o custo médio calculado da tonelada de AFS. Assim pode-se realizar uma projeção dos custos para os anos de 1985 a 1997.

O custo médio do AFS no período de 6 anos (1998-2003) foi de R\$ 75,05 por tonelada e no ano de 2003 foi de $R \$ 91,40$ por tonelada. Neste estudo optou-se por utilizar como base a média de custo de AFS do ano de 2003 (R\$ 91,40 por tonelada) obtendo-se a projeção de custo atualizada. Multiplicando-se o consumo de AFS pelo custo de $\mathbf{R} \$ 91,40$, 
obtém-se o valor estimado para cada ano no período de 1985-1997, atualizado para o ano de 2003.

Para calcular a estimativa de custo total do sistema de fluoretaçāo, composto pelos custos (Custo de Capital Inicial de Instalação, Custo dos Produtos Químicos, Custo de Operacionalização do Sistema e o Custo de Controle), calculou-se o custo médio do produto químico (AFS), no periodo de 1998-2003. O AFS representou em média $74,86 \%$ dos custos totais. A partir deste cálculo foi possivel estimar o custo do sistema ano a ano no período de 1985-1997.

Foi utilizada a fórmula do custo de fluoretação per capita/ano, tendo como Jenominador a estimativa da população do município de São Paulo segundo o Censo Demográfico (IBGE 1980, 1991 e 2000) para o periodo de 1985 a 2000. Para o periodo de 2001 a 2003 foram utilizados os dados da Fundação Seade (SEADE 2003). Obteve-se assim o custo per capita/ano tendo como valor de referência o real (R\$) atualizado para o ano-base de 2003 e o dólar americano (US\$) como referência monetária.

Como visto o país passou por períodos de instabilidades financeiras entre 1985 e 1993. No periodo de agosto de 1994 a 2003, a economia esteve relativamente estabilizada e a moeda brasileira tinha, em relação ao dólar, uma taxa de conversão estável com variação de (US\$ 1,00 $=R \$ 1,00)$ em 1994 e de (US\$1,00 = R\$ 3,06) em 2003. Aa variação média neste periodo de nove anos (1994-2003) foi R\$1,73 por dólar. Assim, no 
periodo de (1985-1993), projetou-se uma taxa de conversão real/dólar de R\$ 1,73 / US\$ 1,00 .

A tabela 5.12 apresenta $\circ$ volume e 0 custo de AFS consumido. $O$ custo de implantação do sistema e o custo estimando per capita/ano em real (R\$) e em dólar (US\$) no periodo de 1985-2003. Ou seja: para manter uma pessoa moradora na cidade de São Paulo beneficiada pala fluoretação, desde a implantação do sistema, (18 anos de benefício) custou R\$ 1,44 (U\$ 0,94) por habitante. 
Tabela 5.12 - Custos de fluoretação das águas de abastecimento público no período de 1985 a 2003 no municipio de São Paulo.

\begin{tabular}{|c|c|c|c|c|c|c|c|}
\hline ANO & $\begin{array}{l}\text { AFS } \\
\text { (ton) }\end{array}$ & $\begin{array}{l}\text { Custo AFS } \\
\text { (R\$) }\end{array}$ & $\begin{array}{l}\text { Custo Total } \\
\text { (RS) }\end{array}$ & População & $\begin{array}{l}\text { Custo } \\
\text { Pessoal } \\
\text { ano (R\$) }\end{array}$ & $\begin{array}{c}\text { *Rela } \\
\text { ção } \\
\text { US\$ / } \\
\text { R\$ }\end{array}$ & $\begin{array}{l}\text { Custo } \\
\text { Pessoa/ ano } \\
\text { (US\$) }\end{array}$ \\
\hline 1985* & 720 & $65.808,00$ & $87.908,10$ & 8.265 .134 & 0,011 & 1,732 & 0,006 \\
\hline 1986 & 4.646 & $424.644,40$ & $567.251,40$ & 8.495 .309 & 0,067 & 1,732 & 0,039 \\
\hline 1987 & 5.474 & $500.323,60$ & $668.345,71$ & 8.725 .484 & 0,077 & 1,732 & 0,044 \\
\hline 1988 & 5.530 & $505.442,00$ & $675.183,01$ & 8.955 .659 & 0,075 & 1,732 & 0,044 \\
\hline 1989 & 5.562 & $508.366,80$ & $679.090,03$ & 9.185 .835 & 0,074 & 1,732 & 0,043 \\
\hline 1990 & 5.730 & $523.722,00$ & $699.601,92$ & 9.416 .010 & 0,074 & 1,732 & 0,043 \\
\hline 1991 & 6.168 & $563.755,20$ & $753.079,35$ & 9.646 .185 & 0,078 & 1,732 & 0,045 \\
\hline 1992 & 5.816 & $531.582,40$ & $710.102,06$ & 9.729 .784 & 0,073 & 1,732 & 0,042 \\
\hline 1993 & 6.690 & $611.466,00$ & $816.812,72$ & 9.813 .383 & 0,083 & 1,732 & 0,048 \\
\hline 1994 & 6.988 & $638.703,20$ & $853.196,90$ & 9.896 .983 & 0,086 & 1,000 & 0,086 \\
\hline 1995 & 7.490 & $684.586,00$ & $914.488,38$ & 9.980581 & 0,092 & 1,000 & 0,092 \\
\hline 1996 & 7.486 & $684.220,40$ & $914.000,00$ & 10.0641 .80 & 0,091 & 1,008 & 0,090 \\
\hline 1997 & 7.370 & $673.618,00$ & $899.837,03$ & 10.147 .779 & 0,089 & 1,081 & 0,082 \\
\hline 1998 & 7.004 & $681.819,86$ & $882.179,96$ & 10.231 .378 & 0,086 & 1,164 & 0,074 \\
\hline 1999 & 7468 & $637.374,69$ & $837.863,45$ & 10.314 .977 & 0,081 & 1,851 & 0,044 \\
\hline 2000 & 7.400 & $613.648,28$ & 813.988 .53 & 10.398 .576 & 0,078 & 1,835 & 0,043 \\
\hline 2001 & 7.316 & $521.769,29$ & $717.575,35$ & 10.482 .175 & 0,068 & 2,353 & 0,029 \\
\hline 2002 & 7.340 & $537.109,64$ & $740.583,76$ & 10.565 .774 & 0,070 & 2,998 & 0,023 \\
\hline 2003 & 7.328 & $667.604,54$ & $887.726,59$ & 10.649 .373 & 0,083 & 3,063 & 0,027 \\
\hline Total & 119.526 & $10.575 .564,30$ & $14.118 .814,25$ & - & R\$ 1,437 & - & US\$ 0,944 \\
\hline Média & 6.291 & $556.608,65$ & $743.095,49$ & - & $R \$ 0,076$ & - & US $\$ 0,050$ \\
\hline
\end{tabular}

*1985 -meses de novembro e dezembro.

*" Fonte: Ribeiro PC, Gazeta Mercantil, 2004.

Nota: Período de 1998 a 2003, valor real atualizado pelo IPC/FIPE.

Periodo de 1985 a 1997, valor estimado. 
5.6 Simulação de custos para implantação de um sistema de fluoretação de águas públicas.

Assim sendo propõe-se elaborar um projeto de custo para implantação de um sistema de fluoretação de águas de abastecimento para cidades de até 5.000 habitantes, de 5.001 a 10.000 hab., de 10.001 a 20.000 hab., de 20.001 a 50.000 hab., e de 50.001 a 100.000 habitantes, com apenas uma Estação de Tratamento de água (ETA).

No Estado de São Paulo, há 128 cidades onde não ocorre a fluoretação em seus sistemas de abastecimentos de água (CRO-SP 2001); a populaçăo residente nestas cidades é de aproximadamente 1.800 .000 (um milhão e oitocentas mil) habitantes que não recebem este benefício.

O planejamento dos custos de implantação de um sistema de fluoretação é fundamental e necessário para viabilizar a implantação do sistema e dimensionar o custo inicial de instalação bem como o custo mensal (CDC, 1991). Algumas informaçōes são fundamentais para a elaboração de um projeto de custos de implantação de uma sistema de fluoretação de águas:

1. Caracteristicas Gerais.
a. População abastecida;
b. Volume de água tratada;
c. Vazão do sistema;
d. Número de ligações do sistema de abastecimento de água. 
2. Compatibilidade do sistema de tratamento.

a. Número de pontos de aplicação $\left(n^{\circ}\right.$ de ETA);

b. Local apropriado para instalação do sistema de fluoretação;

c. Adequação do laboratório para análise dos teores de flúor;

d. Identificação de laboratório independente para análise de contra prova dos teores de flúor (heterocontrole);

e. Local de armazenamento dos produtos químicos;

f. Seleção do produto químico utilizado para a fluoretação;

g. Seleção dos equipamentos para instalação do sistema;

h. Seleção dos equipamentos para análise dos teores de flúor.

3. Caracteristica da água:
a. Teor ideal de flúor $(0,7 \mathrm{ppm})$;
b. Teor de flúor natural da água;
c. Teor a ser incorporado pelo sistema.

4. Outras informações:

a. Identificaçăo da consultoria técnica;

b. Identificação de empresas responsáveis pela instalação dos equipamentos e adequaçăo da rede de tratamento;

c. Treinamento dos recursos humanos para a implantação do sistema;

d. Distância das empresas fornecedoras de produtos químicos (flúor), diferenciando o custo químico com o custo de transporte até a ETA. 
5. Estimativas de custos:

a. Custo de Capital Inicial de Instalação;

- Bomba dosadora;

- Tanque de armazenamento;

- Custo de instalação;

- Custo de equipamentos dosadores;

- Custo de consultoria.

b. Custo de produtos químicos;

- Ácido Fluorsilícico.

c. Custo de Operacionalização;

- Custo de depreciação e manutenção do equipamento;

- Custo de Energia Elétrica;

- Custo de Recursos Humanos.

d. Custo de Controle dos teores de flúor;

- Custo com laboratório para análise;

- Custo dos eletrodos de ín-seletivo de flúor.

Na cidade de São Paulo o consumo de água por habitante variou em média de $200 \mathrm{~m}^{3}$ a $187 \mathrm{~m}^{3}$ de água per capitalano no período entre 1998 e 2003 (tabela 5.11). Em cidades de menor porte, segundo a SABESP (2003), o consumo de água pode chegar a $120 \mathrm{~m}^{3}$ de água per capitalano. Sendo assim, usaremos um consumo médio de água per capitalano de $150 \mathrm{~m}^{3}$, ou seja, 410,96 litros de água por pessoa/dia, presumindo que nas cidades hipotéticas analisadas, $100 \%$ da população é servida pela rede de abastecimento e a água é tratada. 
A concentração ideal de flúor, segundo a média das máximas temperaturas anuais das cidades é de $0,7 \mathrm{mgF} / \mathrm{L}$; supondo que a quantidade de flúor natural existente na água que chega para tratamento é de $0,0 \mathrm{mgF} / \mathrm{L}$, tornando-se necessário acrescentar $0,7 \mathrm{mgF} / \mathrm{L}$ para se obter o concentração ideal para a obtenção de maior benefício e o minimo risco.

Para o cálculo do consumo de flúor da cidade é importante conhecer que a densidade do Ácido Fluorsilícico (AFS) em uma temperatura de $20^{\circ} \mathrm{C}$ é de $1.1748 \mathrm{~g} / \mathrm{cm}^{3}$ AFS, em uma concentração de $20 \%$ de AFS correspondendo a $0,235 \mathrm{Kg} / \mathrm{L}$. Assim, é utilizado um fator de correção de 1,263 (OPAS-OMS 1975; CDC 1991; BUENDIA 1996). O custo por tonelada do AFS incluindo o transporte é de R\$100,00 ton-AFS (SABESP 2003).

A título de exemplo, utilizou-se o cálculo para um município com 20.000 habitantes, que tem um consumo de água de 8.218.200 litros/dia, para realizarmos o vclume de AFS e o custo deste na fluoretação de águas.

$$
\begin{aligned}
& \frac{\text { Concentração de flúor(mg/L) x Vazão de água (Ldia) }}{\text { Fator de conversão } \mathrm{mg} \mathrm{em} \mathrm{Kg}} \\
& \frac{0,7(\mathrm{mg} / \mathrm{L}) \times 8.219 .200(\text { Ldia })}{1.000 .000 \mathrm{mg} / \mathrm{Kg}}=5,7534 \mathrm{Kg} / \mathrm{L}-\mathrm{AFS} / \mathrm{dia}
\end{aligned}
$$


Quantidade AFS(Kg/L) x Fator de correção x Densidade AFS

Concentração AFS Kg/L

$\underline{5,7534(\mathrm{Kg} / \mathrm{L}) \times 1,263 \times 1,1748}=36,3265 \mathrm{Kg} / \mathrm{dia}$

$0,235 \mathrm{Kg} / \mathrm{L}$

$36,3265 \mathrm{Kg} /$ dia $\times 365$ (dias) $=13.259,17 \mathrm{Kg} /$ ano

$13.259,17 \mathrm{Kg} /$ ano $=13,25917$ toneladas $/$ ano

13,225917 ton / ano $\times \mathrm{R} \$ 100,00$ (ton $-\mathrm{AFS}$ ) $=\mathrm{R} \$ 1.325,92$

Será utilizado para o cálculo dos custos do sistema de tratamento a fórmula para o cálculo de custos de fluoretação per capita/ano, proposta neste trabalho.

Custo Fluoretação $=\frac{C C \| l+C P Q+C O S+C C}{\text { População da cidade no ano }}$

CCII = Custo de Capital Inicial de Instalação;

- bomba dosadora automática com microprocessador com motor de 60 Hz e 40 bar e uma vazão de 1,3 a 3,0 litros por hora com custo de R\$2.200,00. Para cidades com mais de 20.000 habitantes será utilizada bomba com mais vazăo a um custo de $R \$ 4.000,00$ (duas bombas por ETA).

- Tanque de armazenamento de AFS com capacidade de $10 \mathrm{~m}^{3}$ à R $\$ 400,00$. Para cidades com mais de 20.000 habitantes os tanque terão a capacidade de armazenamento de $20 \mathrm{~m}^{3}$ a um custo de R\$ 800,00 
- Custo de instalação ( $85 \%$ do custo dos equipamentos).

- Custo do dosador dos teores de íon-seletivo de flúor (R\$ 6.345,00).

- Custo de Consultoria (15\%).

- Total do CCll é dividido por 20 anos, que corresponde ao tempo de depreciação dos equipamentos (o resultado é acrescido ao custo anual).

$\mathrm{CPQ}=$ Custo de Produto Quimico;

- Será calculado conforme o tamanho da população de cada estrato e o volume de água consumido, (para cada faixa populacional, foi utilizado o limite superior desta).

$\cos =$ Custo de Operacionalização do Sistema;

- Depreciação e manutenção dos equipamentos ( $10 \%$ do custo de CCll por ano).

- Energia Elétrica ( $6 \%$ do custo do AFS)

- Recursos Humanos, onde definiu-se que não haverá contratação de funcionário. $\mathrm{O}$ custo de $\mathrm{RH}$ será o de treinamento e reciclagem do pessoal de operacionalização e de laboratório para o sistema de tratamento para o processo de fluoretação das águas sendo que serão 20 horas/aula (custo por hora/aula R\$ 50,00), totalizando um custo com treinamento dos recursos humanos em $R \$ 1.000,00$. 
$\mathrm{CC}=$ Custo de Controle

- O eletrodo de ion-seletivo (custo de $\mathrm{R} \$ 2.000,00$ ), tem um tempo médio de vida de 2 anos e este valor só é incluido após dois anos de implantação do sistema. O laboratório para análise dos teores de flúor deve estar na própria ETA, e além deste, há necessidade de um outro laboratório ou entidade autônoma que deverá fazer os testes de contra prova dos teores de flúor.

A tabela 5.13 apresenta os custos para as cidades segundo o número de habitantes. A relação dos custos per capita / ano, é apresentada com valores em reais e em dólar utilizando uma taxa cambial de US $\$ 1,00$ equivalendo a $R \$ 3,06$, (média da cotação dólar 2003 , conforme RIBEIRO, 2004). 
Tabela 5.13 - Composição de custos da fluoretação da água de abastecimento público para municipios segundo número de habitantes, 2004.

\begin{tabular}{|c|c|c|c|c|c|}
\hline \multirow{2}{*}{$\begin{array}{c}\text { Composiçāo } \\
\text { dos custos } \\
\text { da } \\
\text { fluoretação } \\
\text { das águas. }\end{array}$} & \multicolumn{5}{|c|}{ Número de habitantes } \\
\hline & Até 5.000 & $\begin{array}{c}5.001 \mathrm{a} \\
10.000\end{array}$ & $\begin{array}{c}10.001 \mathrm{a} \\
20.000\end{array}$ & $\begin{array}{c}20.001 a \\
50.000\end{array}$ & $\begin{array}{c}50.0001 \mathrm{a} \\
100.000\end{array}$ \\
\hline $\begin{array}{l}\text { CCII } \\
\text { (RS) }\end{array}$ & 875,44 & 875,44 & 875,44 & $1.300,94$ & $1.300,94$ \\
\hline $\begin{array}{l}\text { CPQ } \\
\text { (RS) }\end{array}$ & 331,49 & 662.96 & $1.325,92$ & $3.314,82$ & $6.629,64$ \\
\hline $\begin{array}{l}\text { COS } \\
\text { (RS) }\end{array}$ & $1.107,43$ & $1.127,32$ & $1.167,10$ & $1.328,98$ & $1.527,87$ \\
\hline $\begin{array}{c}\text { CC } \\
\text { (R\$) }\end{array}$ & - & - & - & - & - \\
\hline $\begin{array}{c}\text { Custo Total } \\
\text { (RS) }\end{array}$ & $2.314,36$ & $2.665,72$ & $3.368,47$ & $5.944,74$ & $9.458,45$ \\
\hline $\begin{array}{c}\text { Custo } \\
\text { Pessoalano } \\
\text { RS }\end{array}$ & 0,46 & 0,27 & 0,17 & 0,12 & 0,09 \\
\hline $\begin{array}{c}\text { Custo } \\
\text { Pessoalano } \\
\text { USS }\end{array}$ & 0,15 & 0,09 & 0,05 & 0,04 & 0,03 \\
\hline
\end{tabular}

Temos que levar em conta que, para instalação inicial dos equipamentos, é necessário um custo de investimento inicial que, para cidades de até 20.000 habitantes é de $\mathbf{R} \$ 17.508,75$ (US\$ $5.721,81$ ) e para cidades de 20.001 a 100.000 habitantes é de R\$26.018,75 (US\$ 8.502,86) que serão diluídos em 20 anos, segundo o tempo de vida útil dos equipamentos. 


\subsection{A relação benefícios /custo da fluoretação}

DAVES (1973), ao analisar o custo beneficio da fluoretação, utilizou a relação Custo do programa/Economia e custos de tratamentos, porém, neste trabalho, optou-se pela inversão desta relação, ou seja, benefício/custos.

Para NIESSEN e DOUGLASS (1984), medir benefícios não é tarefa fácil, pois mensurar ou enquadrar em fórmulas matemáticas representam uma dificuldade na análise de variáveis como "dor evitada" e "sofrimento psíquico". NIESSEN e DOUGLASS (1984) utilizaram o preço de tratamento de mercado, para HOROWITZ e HEIFETZ (1979), o custo do programa deve incluir o número de superfícies ou dentes salvos de cárie dentária, de restauração e de extração.

GRIFFIN et al (2001) utilizaram a equação de HADDIX (1996), comparando comunidades fluoretadas e não fluoretadas, obtendo a efetividade da fluoretação e a diferença no incremento de cárie dentária em grupos etários, através do cálculo do custo por restauração, de manutenção e do tempo de vida útil da restauração, além da expectativa de vida dos individuos da comunidade.

Neste trabalho, as equações de HADDIX (1996) foram utilizadas, embora a comparação foi realizada numa mesma cidade, no caso o município de São Paulo, com períodos diferentes ou seja, antes da fluoretação (base de dados LESB - 1986 MS 1988) e 12 anos após a fluoretação (base de dados LESB - 1998 SES-FSP/USP 1998). O 
levantamento de 1998 foi utilizado pois apresenta as faixas etárias de 7 a 12 anos de idade, necessárias paro o cálculo do incremento de cárie.

Tabela 5.14 - Média do Indice CPO-D segundo idade e a porcentagem de redução da experiência de cárie dentária no período de 1986 e 1998 no município de São Paulo.

\begin{tabular}{ccccc}
\hline Idades & \multicolumn{2}{c}{ CPO -D nos Anos } & $\begin{array}{c}\text { Diferença } \\
\text { CPO- } \mathrm{D}_{86-98}\end{array}$ & $\begin{array}{c}\text { Porcentagem de } \\
\text { redução da cárie } \\
(\%)\end{array}$ \\
\hline 7 & 1986 & 1998 & 1,77 & 85,5 \\
8 & 2,07 & 0,30 & 2,19 & 81,1 \\
9 & 2,70 & 0,51 & 2,54 & 70,8 \\
10 & 3,59 & 1,05 & 2,99 & 72,8 \\
11 & 4,11 & 1,12 & 3,56 & 68,9 \\
12 & 5,17 & 1,61 & 4,41 & 68,2 \\
\hline
\end{tabular}

A efetividade após 12 anos de fluoretação no município de São Paulo reflete-se nos resultados obtidos pela diferença de CPO-D antes e após a fluoretação $\left(\mathrm{CPOD}_{86}-\mathrm{CPOD}_{98}\right)$ dividindo-se pelo CPO-D antes da fluoretação, (CPO-D $\left.{ }_{86}\right)$, (HADDIX 1996). Para obter-se o resultado em porcentagem, multiplica-se por 100 . Os resultados mostram uma efetividade de redução de cárie dentária de $68,2 \%$ aos 12 anos e $85,5 \%$ aos 7 anos de idade (tabela 5.14). Analisando os dados do LESB-2002 (SES-FSP/USP 2003) e aplicando o mesmo método, a efetividade da fluoretação chega a $73,1 \%$ aos 12 anos de idade. 
Tabela 5.15 - Média do Índice CPO-D, incremento de cárie por idade e a média nas faixas etárias de 7 a 12 anos de idade no periodo de 1986 e 1998 no municipio de São Paulo.

\begin{tabular}{ccccc}
\hline Idades & CPO- $\mathrm{D}_{86}$ & $\begin{array}{c}\text { Incremento } \\
\text { de cárie } \\
\text { por idade - 86 }\end{array}$ & CPO- $\mathrm{D}_{98}$ & $\begin{array}{c}\text { Incremento } \\
\text { de cárie } \\
\text { por idade - 98 }\end{array}$ \\
\hline 7 & 2,07 & - & 0,30 & - \\
8 & 2,70 & 0,63 & 0,51 & 0,21 \\
9 & 3,59 & 0,89 & 1,05 & 0,54 \\
10 & 4,11 & 0,52 & 1,12 & 0,07 \\
11 & 5,17 & 1,06 & 1,61 & 0,49 \\
12 & 6,47 & 1,30 & 2,06 & 0,45 \\
\hline $\begin{array}{c}\text { Média de } \\
\text { Incremento } \\
\text { de cárie }\end{array}$ & - & 0,88 & - & 0,35 \\
\hline
\end{tabular}

A tabela 5.15 mostra a média do índice CPO-D nos anos de 1986 e 1998 para as idades 7 a 12 anos e o incremento de cárie dentária na dentição permanente, ou seja, o aumento na experiência de cárie de uma idade para a outra. Assim, é possível obter-se a média de incremento de cárie no grupo etário de 7 a 12 anos, nos respectivos anos que foram de 0,88 (1986) e 0,35 (1998).

A diferença de incremento de cárie $(0,88-0,35=0,53)$ representa o aumento médio de cárie dentária por idade/ano que ocorreria se não houvesse a fluoretação das águas (HADDIX 1996). 
Multiplicando-se este resultado $(0,53)$ pelo preço médio de um procedimento odontológico (R\$ 50,00 ) no setor privado, teremos como resultado o valor da Economia de Custos por pessoa / ano ( $R \$ 26,50)$. Além deste cálculo, pode-se multiplicar o mesmo valor pelo custo médio de um procedimento odontológico, tendo como referência a tabela do SIA-SUS (R\$ 12,00) No setor público, este valor representa, para o SUS, uma economia de custos de R\$ 6,36 por pessoa/ano em tratamentos odontológicos somente no grupo etário de 7 a 12 anos de idade.

Aplicando a equação de benefício/custo proposta por DAVIES (1973) e invertida neste trabalho, onde o numerador representa a economia de custos por pessoa/ano, do programa (R\$ 26,50 para os serviços odontológicos ou R\$ 6,36 para o sistema público de saúde) e o denominador o custo médio do custo da fluoretação desde a sua implantação (R\$ 0,076), por pessoa lano - Serviços odontológicos $\frac{R \$ 26,50}{R \$ 0,076}=R \$ 348,68$

- Serviços do SUS $\frac{R \$ 6,36}{R \$ 0,076}=R \$ 83,68$ 
Estes resultados demonstram que, tanto utilizado como base de cálculo do serviço privado ou como a referência do serviço público, o beneficio/custo da fluoretação é muito grande pois, para cada $R \$ 1,00$ investido por pessoa/ano para fluoretação, tem-se uma economia de $\mathrm{R} \$ 348,68$ no serviço privado e $\mathrm{R} \$ 83,68$ para o serviço público por pessoa/ano, apenas no grupo etário de 7 a 12 anos.

Convertendo-se este valor em dólar (numa relação de US\$1,00 para $R \$ 3,06$ - média de 2003) teremos, para cada dólar investido na fluoretação, uma economia de US $\$ 113,95$ (para o serviço privado) e US\$27,35 (para o serviço público).

Tabela 5.16 - Equação da relação Benefício/Custo e seus componentes segundo sistema privado e público (real e dólar) para avaliação do sistema de fluoretação das águas de abastecimento no município de São Paulo, 2004.

\begin{tabular}{ccccccc}
\hline Serviços & $\begin{array}{c}\text { Incremento } \\
\text { de cárie de 7 } \\
\text { a 12 anos }\end{array}$ & Moeda & $\begin{array}{c}\text { Custo médio } \\
\text { Proc. } \\
\text { odontológicos }\end{array}$ & $\begin{array}{c}\text { Economia de } \\
\text { custo } \\
\text { Pessoa/ano }\end{array}$ & $\begin{array}{c}\text { Custo médio } \\
\text { fluoretaçăo } \\
\text { Pessoa/ano }\end{array}$ & $\begin{array}{c}\text { Relaçáo } \\
\text { bem/custo } \\
\text { Pessoa/ano }\end{array}$ \\
\hline Privado & 0,53 & R\$ & 50,00 & 26,50 & 0,076 & $\mathbf{3 4 8 , 6 8}$ \\
\hline & US\$ & - & - & 0,025 & $\mathbf{1 1 3 , 9 5}$ \\
\hline Público & 0,53 & RS & 12,00 & 6,36 & 0,076 & $\mathbf{8 3 , 6 8}$ \\
\hline
\end{tabular}




\section{6 - DISCUSSÃO}

O uso racional dos recursos hidricos e o aproveitamento destes de maneira equilibrada, são fatores fundamentais para o desenvolvimento social e para evitar a escassez destes, primordiais para a sobrevivência humana. A fluoretação das águas encontra-se incluída nestes princípios de aproveitamento racional dos recursos hídricos visando a melhoria da qualidade de vida da população.

A fluoretação de águas de abastecimento público representa, desde 0 início de sua implantação, na década de 40 nos EUA, a medida preventiva de maior impacto em saúde bucal, em termos populacionais. Não há registros de Jeclínio de prevalência de cárie tão significativos, no mundo inteiro, como os que são possiveis verificar após a adição de flúor às águas que uma população consome.

O caráter universal da medida, não privilegiando agrupamentos sociais e atingindo de forma eqüitativa populações que, tradicionalmente, são excluídas de benefícios de promoção em saúde, justifica ações por parte do Estado que garantam este direito da população, que já está consolidado por marcos legais há cerca de 30 anos no caso do Brasil.

Passados 50 anos desde a primeira fluoretação de águas no pais é alarmante que ainda hoje $66 \%$ da população brasileira não tenha tido acesso à água fluoretada, incluindo 11 capitais. 
Os governos federais, estaduais e municipais, responsáveis pela formulação, administração e gerenciamento de políticas públicas de saúde do país têm o dever de viabilizar administrativa e tecnicamente este beneficio à população, que deve vir acompanhado de uma política mais abrangente de saneamento básico e acesso à água tratada. Assim, pode-se afirmar que a decisão de fluoretar as águas de um municipio é de caráter eminentemente político.

Atualmente, não há sustentação legal e nem mesmo fundamentação técnica para a não fluoretação de águas no Brasil. Este método preventivo comprovou-se eficiente, seguro, de baixo custo e abrangente.

\subsection{Fluoretação no município de São Paulo}

Pode-se observar que, no periodo anterior à fluoretação das águas de abastecimento público na cidade de São Paulo, a cárie dentária na população de 7 a 12 anos de idade mantinha-se em um patamar elevado, sem ocorrer mudanças estatisticamente significantes de 1970 a 1986 nos valores do CPO-D, tendo em média um incremento de 0,88 dentes atacados por cárie a cada ano de vida (Gráficos 5.1 a 5.6).

Segundo dados epidemiológicos coletados 10 anos após a fluoretação das águas, pode-se observar que ocorreu uma redução do nivel 
de doença com mudanças estatisticamente significativas, diferente do padrão da doença no periodo anterior a fluoretação. Segundo os dados apresentados na tabela 5.1, pode-se observar uma grande redução nos níveis da doença nos primeiros 10 anos de implantação deste método preventivo e uma redução menor no periodo dos 10 ao 16 anos pós fluoretação, observa-se uma estabilidade com suave redução nos padrōes da doença, embora sem diferença estatisticamente significante. Nos gráficos 5.1 a 5.6 observa-se a tendência histórica do comportamento epidemiológico da cárie dentária nas idades de 7 aos 12 anos.

Segundo dados da SABESP, com relação ao acesso à rede de abastecimento, no período posterior a fluoretação, houve um aumento significativo da população abastecida por água tratada e fluoretada, chegando a um patamar de $100 \%$ da população residente na cidade abastecida pela rede de água. Pode-se, assim, afirmar que toda a população está tendo acesso ao benefício da fluoretação das águas, independente da condição social, do nivel econômico da renda per capita e da idade, ou seja, há um acesso universal a este benefício para a saúde e, conseqüentemente, à saúde bucal, já que esta água é fluoretada.

Os dados se contrapõem aos dados da Fundação IBGE (2004), onde $1,4 \%$ da população da cidade de São Paulo não tem acesso a água tratada ou seja, aproximadamente 149.092 pessoas desprovidas deste beneficio e, conseqüentemente, sem acesso ao flúor. 
A fluoretação das águas pode ser monitorada segundo os relatórios de heterocontrole da fluoretação das águas da PMSP (gráfico 5.8) e o relatório da SABESP (tabela 5.4), conforme os níveis de ácido fluorsilicico utilizados na estação de tratamento. Embora tenham ocorrido valores fora do recomendado (entre 0,6 a $0,7 \mathrm{ppm}$ ), devido, principalmente, à falta do produto (AFS) no mercado como comprovam os dois relatórios, este problema já foi sanado nos últimos 9 anos, ou seja, de 1993 a 2002 , propiciando assim, um acesso da população à água com o beneficio do flúor dentro dos parâmetros ideais.

Segundo FREITAS (2001), a grande redução na prevalência da cárie dentária em nivel populacional foi resultado da aplicação de métodos de prevenção em massa, baseados na fluoretação das águas de abastecimento público e no acesso de uma grande parcela da população ao uso de dentifrícios fluoretados que mudaram o padrão da doença com maior efetividade que a prática individualizada dos dentistas.

FREITAS (2001) ressalta que a fluoretação das águas de abastecimento tem papel estratégico na maioria dos paises, por ser um método seguro, de baixo custo, de fácil aplicação e de grande alcance, sendo o principal mecanismo de redução da cárie dentária em comunidades que contam com acesso a apenas este método, devido às caracteristicas econômicas, políticas e sociais, já que estas comunidades são excluidas de outros métodos tópicos com regularidade, além da falta de acesso a assistência básica de saúde bucal. 
Vale ressaltar algumas limitações desta pesquisa, pois, ao focalizar o custo da fluoretação, não se aborda outras variáveis possivelmente intervenientes, que podem ter tanto papel positivo como negativo nos niveis de doença e que não foram controladas no presente estudo.

Dentre as variáveis que podem ter tido interferência nos padrões da doença nestes últimos 17 anos na cidade de São Paulo destacase a fluoretação do creme dental, a melhoria no padrão e na qualidade de vida, a implantação do SUS, e a municipalização da saúde e o acesso da população às ações individuais de assistência e às ações coletivas de saúde com caráter preventivo/educativo da população.

A partir de 1988, a população teve acesso ao creme dental fluoretado no Brasil, representando um grande avanço para a saúde pública pois este é mais um método de prevenção à cárie dentária, regulamentada pelo portaria federal $n^{\circ} 22$ de 20/dez/1989 (SNVS 1989). Segundo CURY (1989), "quando a população tem o hábito de escovar os dentes, o flúor no dentifricio é tão abrangente quanto à água fluoretada, em termos de saúde pública, com relação ao efeito cariostático".

Ainda segundo CURY (2003), até setembro de 1988 apenas $25 \%$ dos cremes dentais comercializados no Brasil apresentavam flúor. A partir desta data houve um aumento significativo e, em 2003, praticamente todos os cremes dentais apresentavam flúor em sua composição. $O$ consumo de creme dental per capita no Brasil é de 1,4g/dia (CURY 1998) e 
a diminuição na prevalência de cárie dentária pode chegar a $20 \%$ após dois anos de uso contínuo de creme dental fluoretado (MURRY 1992; PINTO 2000).

Observa-se uma melhora no padrão de vida e qualidade de vida na capital paulista nestas últimas duas décadas. Estas afirmações são sustentadas por alguns indicadores de saúde como a diminuição do coeficiente de mortalidade infantil para 15,1\%o em 2002 (SEADE 2003); melhora no IDH-M que era de 0,740 em 1980, e era de 0,804 em 1991 e que registrou o valor de 0,841 em 2003, caracterizando-se, assim, como uma cidade com alto desenvolvimento humano (SEADE 2003).

A partir de 1988, a política de saúde no Brasil sofreu uma profunda mudança no que se refere ao aspecto político, organizacional, financiamento e acesso aos serviços de saúde. Antes da implantação do SUS, apenas servidores públicos e trabalhadores formalmente vinculados à Previdência Social tinham acesso aos serviços públicos de saúde e, após a promulgação da constituição de 1988 , todos passam a ter direito de acesso as ações e serviços de saúde para sua promoção, proteção e recuperação (BRASIL 1988).

De 1989 a 2002, ocorreram distintas formas de organizar a saúde pública na cidade de São Paulo. Durante os quatro primeiros anos deste periodo, o Governo Municipal iniciou o processo de municipalização da saúde e implantação do SUS, com mudanças no plano politico. As duas gestōes que sucederam-se neste periodo tomaram rumos diferentes. Em 
1995, foram implantadas cooperativas de saúde e, o sistema de saúde "PAS" (plano de assistência à saúde) adotado pela secretaria municipal, feriu muitos preceitos constitucionais (COHEN e ELIAS 2001) prevista pela Lei federal n 8.080 (BRASIL 1990). Entre eles, a não apreciaçăo do "PAS" à participação popular por meio do Conselho de Saúde, que foi destituido de suas funçōes dentro do sistema (SÁ et al 1997). Este sistema de saúde permaneceu até 2001 quando novamente a política tomou outro rumo, retornando os principios e as diretrizes constitucionais que regulamentaram a implantação do SUS.

Assim sendo, o SUS tem sua plena implantação na cidade apenas em 2002, quando ocorreu a municipalização da saúde, a transferência de equipamentos de saúde de Unidades Básicas de Saúde e de Hospitais - antes gerenciados pelo Estado e na ocasião repassadas para a gerencia municipal - e a transferência de recursos, com os repasses de verbas de nivel Estadual e Federal, que haviam sido suspensos no periodo de implantação do "PAS".

Segundo NARVAl et al (2000), o acesso às ações coletivas de saúde bucal tem um aspecto fundamental para a mudança no padrăo da doença, contribuindo para a redução dos niveis de doença. Este fato destaca-se principalmente quando se trabalha com conceitos epidemiológicos de identificação de grupos de risco na população para definir a programação das ações de saúde bucal levando-se em conta não só o risco individual mas também o risco familiar e coletivo, referente ao 
acesso a bens de serviço, acesso aos bens de consumo, aos aspectos sócio-econômicos, culturais, e comportamentais como ressalta FREITAS (2001).

É possivel que essas variáveis também tenham contribuição no modelo no qual a cárie dentária teve redução no municipio de São Paulo nestas duas décadas. É dificil dissociar as variáveis em estudos ecológicos com medidas realizadas em pesquisas através de delineamento transversal.

Um contraponto a estas variáveis é observado pois, que, apesar dos avanços nos indicadores de qualidade de vida (CMI e IDH-M), os indicadores econômicos não são favoráveis, pois $40,06 \%$ dos responsáveis pelos domicilios têm renda inferior a três salários mínimos (SEADE 2003) e o Indice Gini de 0,57 reflete a desigualdade social e o desequilibrio na distribuição de renda. Assim pose-se admitir que parte significativa desta população, desprovida de recursos econômicos não tenha acesso ao creme dental com flúor, agrava este quadro o fato de que o creme dental como outros métodos de controle de cárie, para ser efetivo, depende da freqüência e da regularidade de aplicação. A questão torna-se mais grave quando se sabe que em alguns domicilios a mesma escova dental (que é de uso individual) é utilizada por todos os familiares.

Em termos de acesso a serviços de saúde, a problematização destaca-se pelo fato de tratar-se de uma população economicamente desprovida de recursos, que é quase exclusivamente dependente do sistema público de saúde. Embora a implantação do SUS tenha sido um 
grande avanço na melhoria de acesso e na qualidade de serviços prestados à população, a área de saúde bucal ainda requer muito com relação à ampliação dos serviços pois, segundo dados da Secretaria de Estado de Saúde, em 1998, 12,15\% da população tiveram acesso à assistência odontológica e $14,19 \%$ da população de 0 a 14 anos de idade foram cobertos com procedimentos coletivos (SES-SP 2002).

Pode-se, assim, afirmar com garantia que o flúor na água de abastecimento foi o único método preventivo de controle da cárie dentária em que a população teve acesso de forma equânime e com freqüência constante comprovada pelos registros da Sabesp e pelo heterocontrole desde a sua implantação em 1985. Sendo assim, a população foi exposta ao benefício independente da sua condição sócio-econômica, cultural ou comportamental, sua faixa etária, etnia ou sexo.

\subsection{Análise dos custos da fluoretação}

Com a análise dos custos no período de 1985 a 2003, é possivel observar que 0 montante gasto para proteger um indivíduo, morador da cidade de São Paulo, com flúor na água de abastecimento desde a implantação do sistema de fluoretação da mesma, ou seja, numa análise histórica, passados 18 anos desde a fluoretação das águas do municipio de São Paulo, o custo foi de $\mathrm{R} \$ 14.118 .814,25$ o que equivale a $\mathrm{R} \$ 1,44$ (US\$ 0,94) por habitante; este valor é expressivamente menor que o 
custo de uma restauração de uma face de amálgama ou de uma extração dentária, confirmado assim o baixo custo da medida frente ao importante benefício que ela propiciou para a população neste periodo.

Além do beneficio diretamente ligado à saúde bucal, torna-se necessária a abordagem social deste beneficio. A diminuição na demanda por assistência individual de urgência acarreta diminuição no absenteísmo escolar e no trabalho além da economia financeira em casos de necessidade de tratamentos mais complexos.

Estes recursos públicos que foram economizados poderiam ter sido direcionados a programas de prevenção, de educação e identificação de grupos de alto risco que tên necessidades especiais e prioridades na atenção e na assistência em saúde bucal, mudando a práxis do clássico modelo mutilador que caracterizou a saúde bucal brasileira durante as últimas décadas.

Antes da fluoretação, apenas $5 \%$ das crianças na idade de 12 anos não tinha experiência de cárie dentária na dentição permanente no municipio de São Paulo, ou seja CPO-D igual a zero (BRASIL 1988) e, segundo dados epidemiológicos realizados em três levantamentos distintos no período de 1996 a 2002, observou-se que a porcentagem de crianças livres de cárie dentária ao 12 elevou-se em média para 40\% (SÃO PAULO 1997, 1998, 2002), ou seja, diminuiu consideravelmente o número de crianças que tiveram contato com a cárie dentária em idade precoce. 
O custo médio per capita/ano da fluoretação na cidade de São Paulo foi de R\$ 0,08 (US\$0,03) e, mesmo se o custo da fluoretação fosse 100 vezes maior, ou seja, passasse a ser de $\mathrm{R} \$ 7,60$ (US\$2,48), ainda assim, a fluoretaçăo acarretaria em beneficios incalculáveis, justificando a sua implantação nos sistemas de abastecimento de água do Estado de São Paulo e no Brasil, evitando prejuizos à saúde bucal das comunidades e melhorardo a qualidade de vida dos individuos.

Tendo um custo tão reduzido, espera-se um aumento na cobertura da população brasileira ao acesso à água tratada e fluoretada.

Para que este meta seja cumprida, as políticas públicas de atenção em saúde devem visar a promoção, proteção e recuperação, visando a melhoria da qualidade de vida. As ações de saúde devem ser implantadas voltadas para o bem estar social de toda a população, minimizando as desigualdades sociais que têm marcas profundas no Brasil, e têm raizes consolidadas desde a colonização do país. A fluoretação das águas é um dos melhores mecanismos para favorecer a redução dos abismos sociais no acesso ao flúor e à saúde bucal, compensando a limitaçăo decorrente da iniqüidade social do país. Para que isto ocorra, é necessário que os municipios cumpram a Lei Federal $n^{\circ} 6.050 / 74$, que tornou obrigatória a fluoretação das águas de abastecimento público em todo território nacional (BRASIL 1976).

Podemos observar que o custo com o tratamento de água de abastecimento ocorrido na cidade de São Paulo no periodo de 1998 a 2003 
(tabela 5.7) teve um aumento nos últimos anos, destacando o custo de energia elétrica que passou de 5,61\% em 1998 para 8,23\% em 2003 (custo de tratamento de água). Os custos com os produtos químicos (incluindo o flúor) representaram de $53,4 \%$ a $59,6 \%$ do total de custos com o tratamento e o custo com o ácido fluorsilícico variou de $1,89 \%$ a $3,65 \%$, com um valor médio de $2,45 \%$ na composição total dos custos de tratamento.

Embora alguns autores (WHITE et al 1989; CDC 1991), destaquem que o custo do AFS como de grande peso na fluoretação das águas, este tem uma pequena representatividade $(2,45 \%)$, se comparado com o montante de recursos empregados no tratamento de água no periodo de 1998 a 2003.

Alguns criticos da fluoretação alegam que o custo é elevado. Para uma cidade com aproximadamente dez milhões de pessoas como o município de São Paulo, este custo sempre terá um valor extremamente pequeno, pois o mesmo dilui-se devido ao tamanho da população.

Comparando-se os resultados do custo da fluoretação no municipio de São Paulo e a simulação de custos para municípios de 50.001 a 100.000 habitantes, observamos que o custo para estes municípios é de R\$ 0,09 (US\$ 0,03 ) e muito próximo ao custo médio obtido para o municipio de São Paulo R\$ 0,08 (US\$ 0,03 ) ou seja uma diferença de apenas 1 centavo.

Segundo a pesquisa de RINGELBERG et al (1992) em pesquisa realizada em 44 comunidades da Flórida (EUA), o custo da 
fluoretação das águas em comunidades com população de 10.000 a 50.000 habitantes é de US\$ 0,68 per capita/ano, comparando estes resultados com municipios brasileiros (US $\$ 0,04$ per capita/ano), na mesma faixa populacional (20.001 a 50.000 habitantes) pode-se notar uma grande diferença de custos, ou seja, uma valor 17 vezes menor no Brasil que na Florida (EUA).

Para comunidades de até 10.000 habitantes RINGELBERG et al (1992) encontraram um custo médio de US\$2,12 por habitante/ano. Neste trabalho, o valor obtido foi de US $\$ 0,15$ por habitante/ano para comunidades com até 5.000 pessoas e de US $\$ 0,09$ por habitante/ano para cidades com uma população de 5.001 a 10.000 habitantes, um valor muito inferior aos encontrados pelos autores citados.

Um custo entre $R \$ 0,46$ e $R \$ 0,09$ (U\$ 0,15 a U $\$ 0,03$ ), por pessoa/ano representa um valor extremamente baixo se comparado ao benefício observado após 10 anos de implantação do sistema. Estes beneficios se refletem na redução, em média, de $60 \%$ na prevalência de cárie dentária (BROWN et al 1959; RIPA 1993); na diminuição significativa do número de pessoas com experiências de cárie dentária além do benefício social que esta medida proporciona, como diminuição de dor, "sofrimento psíquico" (DAVIES 1973), "mutilação dentária" (NARVAI 2000a), traumas fisicos e emocionais, obtendo-se assim, uma melhoria na qualidade de vida (WHITE et al 1998). 
Segundo CHAVES (1953a) e CALVO (1996), o custo inicial na compra de equipamentos e adequação da rede de abastecimento de água para implantação do sistema de fluoretação é o maior empecilho para que ele não ocorra.

Como demonstrado através dos resultados na tabela 5.14 , os custos de instalação inicial dos equipamentos em municipios de até 20.000 habitantes foi calculado em R\$17.508,75 e para cidades de 20.001 a 100.000 habitantes foi de $\mathrm{R} \$ 26.018,75$, que representa um valor relativamente baixo levando-se em conta o beneficio para os habitantes. Além do baixo custo do investimento inicial, os equipamentos apresentam um tempo de vida útil de em média, 20 anos diluindo o valor do investimento inicial. Não justificando, assim a afirmação de que o alto custo de instalação dos equipamentos para o sistema de fluoretação inviabiliza a implantação do sistema.

Muitos municipios brasileiros ainda não adotaram as medidas necessárias para a implantação do sistema de fluoretação. Embora conste na lei que determinou a fluoretação das águas (Lei Federal $n^{\circ} 6.050$ de 24/05/1974) uma previsão de financiamento destinado à implantação do sistema de fluoretação. Além disto observa-se uma omissão por parte dos poderes públicos na viabilização dos recursos para implantação do sistema de fluoretação nos municipios, embora conste no Art $5^{\circ}$ do Decreto Federal 76.872 de $24 / 12 / 1974$. 
Para a análise de custos e benefícios de programas é muito importante o dimensionamento da abrangência do programa e o tempo que este foi implantado (NIESSEN e DOUGLASS 1984). O programa de fluoretação da cidade de São Paulo foi implantando em outubro de 1985, ou seja, há 18 anos, e tem uma cobertura de $100 \%$ da população (SABESP 2003), ou $98,6 \%$ segundo a Fundação IBGE (2004).

A análise dos resultados da relação benefício/custo da fluoretaçăo que utilizou como base de cálculo o serviço privado e o serviço público, demonstrou-se que benefício/custo é muito grande pois, para cada R\$ 1,00 investido por pessoa/ano para fluoretação, tem-se uma economia de $R \$ 348,68$ (US\$ 113,95 ) no serviço privado e $R \$ 83,68$ (US\$ 27,35 ) para o serviço público por pessoa/ano, apenas no grupo etário de 7 a 12 anos.

GRIFFIN et al (2001) encontraram uma economia de US\$ 18,62 em tratamento dentário por pessoa/ano para grandes comunidades. Em comparação com os resultados encontrados na cidade de São Paulo decorrentes da fluoretação das águas de abastecimento, houve uma economia em tratamento dentário 1,5 vezes maior no serviço público (SUS) e 6 vezes maior no serviço privado.

Além destes resultados, extremamente favoráveis quanto à efetividade da fluoretação das águas de abastecimento, o baixo custo, a grande economia de custo ou seja, o grande benefício em relação aos custos, não se pode deixar de salientar que, em média, $40 \%$ de crianças aos 12 anos não têm experiência de cárie na dentição permanente, todos estes 
beneficios a um custo médio de $\mathrm{R} \$ 0,08$ (US\$ 0,03 ), por pessoa/ano, valor este mais baixo que o preço médio de uma bala de caramelo.

A análise de custo-beneficio "destina-se a avaliar a viabilidade econômica de projetos sociais, podendo-se aplicá-los a um determinado programa ou a vários, para compará-los em termos de sua rentabilidade social" (UGÁ, 1995). A fluoretação das águas é uma ação de alta eficiência, de baixo custo e grande benefício. Representa uma decisão politica, economicamente viável, socialmente justa e, segundo MAIER (1970), uma "medida revolucionária" pois promove uma transformação social no perfil epidemiológico da cárie dentária, diminuindo a desigualdade social ao acesso a produtos fluoretados inclusive pela população de estratos sociais mais baixos. A medida significa uma melhora na qualidade de vida, contribuindo assim para tornar as pessoas mais felizes e evitando o constrangimento ao sorrir sem a vergonha de mostrar arcos dentários mutilados ou com dentes parcialmente destruidos. Tais beneficios, intangiveis não podem ser avaliados uma vez que seu valor envolve subjetividade não alcançada por modelos de base monetária.

É importante salientar que, devido os beneficios que esta oferece, torna-se uma medida imprescindivel, a fluoretação das águas de abastecimento permite aos gestores das políticas públicas de saúde bucal dos municipios uma reformulação destas em termos de priorização da atenção e reorganização do sistema de assistência, na medida em que o perfil epidemiológico da população se altera; permite ainda ampliar o acesso 
à atenção a uma parcela maior da população, sem priorizar grupos etários e buscando uma resolubilidade maior principalmente nos grupos populacionais de alto risco de doença. 


\section{CONCLUSÃo}

Tendo em vista os objetivos e a análise dos resultados obtidos nesta pesquisa concluiu-se que:

7.1 - Antes da implantação da fluoretação das águas no município de São Paulo o valor do índice CPO-D era 6,74 (6,12-6,82), em 1986, em crianças de 12 anos de idade. Após 18 anos desde a implantação e manutenção dessa medida preventiva constatou-se uma redução da ordem de $73 \%$ no valor desse indice registrando-se $1,75(1,48-2,02)$ em 2002;

7.2 - No período de 1989 a 1992 ocorreu, em alguns meses, menor adição de ácido fluorsilícico na água de abastecimento. Após 1993 os teores estiveram dentro dos padrōes aceitáveis, até 2003. Assim, pode-se admitir que no período de 1985 a 2003 a população paulistana esteve exposta a niveis suficientes e seguros de flúor na água de abastecimento para produzir os efeitos preventivos desejados;

7.3 - A estimativa de custos da SABESP para fluoretar a água do município de São Paulo, em 2003, foi de R\$ 887.726,59 (oitocentos e oitenta e sete mil, setecentos e vinte seis reais, e cinqüenta e nove centavos) para uma população de 10.649.373 habitantes. Tal valor equivale a US\$ $290.106,72$. O custo per capitalano foi de R\$ 0,08 (US\$ 0,03) em 2003; 
7.4 - A relação de benefício/custo indica que para cada real empregado na fluoretaçăo houve uma economia de $\mathrm{R} \$ 348,68$ (US\$ 113,95) para dispêndios que seriam realizados no setor privado e de $\mathrm{R} \$ 83,68$ (US\$27,35) para custos que teriam onerado o orçamento do setor público, por pessoa/ano, apenas no grupo etário de 7 a 12 anos;

7.5 - As estimativas de custos para municípios com populações de até 5.000 habitantes foi de $R \$ 0,46$ (US\$ 0,15 ), de $R \$ 0,27$ (US\$ 0,09) para populações de 5.001 a 10.000 habitantes; de R\$ 0,17 (US\$ 0,05) para populações de 10.001 a 20.000 habitantes; de R\$ 0,12 (US\$ 0,04) para populações de 20.001 a 50.000 habitantes; e de R 0,09 (US\$ 0,03) para populações de 50.001 a 100.000 habitantes.

O custo de implantação e manutenção da fluoretação da água durante 18 anos (período de 1985 a 2003) foi de $R \$ 14.118 .814,25$ (quatorze milhões, cento e dezoito mil, oitocentos e quatorze reais, e vinte e cinco centavos), valor este equivalente a US\$ 4.613.991,59. Tal custo corresponde aos gastos com a implantação do sistema, instalações, produto químico, e sua operacionalização e controle. Isto corresponde a um custo per capita de $R \$ 1,44$ (US\$ 0,94).

Pode-se admitir que tais custos corresponderam a uma adequada alocação de recursos financeiros uma vez que, em termos 
preventivos, contribuiram para reduzir em $73 \%$ o valor do índice CPO-D na idade de 12 anos, no periodo de 1985-2002.

O significado sanitário da fluoretação das águas de abastecimento público pode ser inferido do fato de que, em 1986, apenas $5 \%$ dos escolares do municipio de São Paulo estavam livres da cárie dentária mas, em 2002, essa porcentagem havia aumentado para $40 \%$.

Ainda que se reconheça que a cárie é uma doença multifatorial e que, portanto, muitas variáveis estão envolvidas em sua patogênese, é inegável a contribuição da fluoretação das águas, uma típica intervenção de saúde pública, para sua prevençăo e controle. Ao se cotejar custos e beneficios, conforme realizado nesta it:vestigação, resulta evidente que essa medida apresenta características econômicas e de eficácia preventiva que a tornam uma tecnologia indispensável no combate à cárie, constituindo-se em possibilidade efetiva de garantir o exercício de direitos de cidadania em saúde. 


\section{REFERÊNCIAS BIBLIOGRÁFICAS}

1. Ainamo J. The decline of dental caries in European countries. in: Frank RM, O'Hickey S. Strategy for caries prevention in European countries according to their laws and regulations. Oxford: IRL press $1987 ; 21$ 36.

2. Al-Mohammadi SM, Rugg-gun AJ, Butler TJ. Caries prevalence in boys aged 2, 4 and 6 years according to socio-economic status in Riyadh, Saudi Arabia. Community Dent Oral Epidemiol. 1997; 25: 184-6.

3. [APHA] American Public Health Association, American Water Works Association, Water Pollution Control Federation, Standard Methods for the examination of water and westewater, $16^{\text {th }}$ 1985: $p$ 357-61.

4. Arnold FA Jr, Likins RC, Russell AL, Scott DB. Fifteenth year of the Grand Rapids fluoridation study. J America Dental Assoc. 1962; 65: 780-5.

5. Ast DB, Cons NC, Pollard ST, Garfinkel J. Time and cost factors to provide regular periodic dental care for children in a fluoridated and non-fluoridated area: final report. J America Dental Assoc. 1970; 80(4): 770-6.

6. Attwood D, Blinkhorn AS. Reassessment of the effect of fluoridation on cost of dental treatment among Scottish schoolchildren. Community Dent Oral Epidemiology 1989; 17(13): 79-82.

7. Baldani NH, Narvai PC, Antunes JLF. Cárie dentária e condiçōes sócioeconômicas no Estado do Paraná, Brasil 1996. Cadernos de Saúde Pública. 2002; 18(3): 755-63. 
8. Battellino LJ, Cornejo LS, Cattoni STD, Yankilevich ERLM, Azcura AI, Virga C. Evaluación del estado de salud bucodental en preescolares: estudio epidemiológico longitudinal (1993-1994), Córdoba, Argentina. Rev Saúde Pública 1997; 31(3): 272-81.

9. Barbisan AO, Ribeiro CRM, Fossati GF, Caminha JAN, Edler OS. Implicação econômica - familiar decorrente da fluoretação de águas de abastecimento público no Rio Grande do Sul. Rev Fac Odont Porto Alegre. 1970; 12: 35-44.

10. Birch $S$. The relative cost effectiveness of water fluoridation across communities: analysis of variations according to underlying caries levels. Community Dental Health 1990; 7(1): 3-10.

11. Birkeland JM, Haugejorden O, Ramn von der Fehr F. Some factors associated with the caries decline among norwegian children and adolescents: age-specific and cohort analyses. Caries Research. 2000; 34 (2): 109-16.

12. Black GV, McKay FS. Mottled Teeth: an endemic developmental imperfection of the teeth, heretofore unknow in the literature of dentistry. Dental Cosmos 1916: 58: 129-56.

13. Brasil. Coleção das Leis de 1974: Lei Federal nº 6.050 de 24/05/1974. Brasilia: Departamento de Imprensa Nacional; 1974. [Vol III: p 107. Atos do Poder Legislativo. Leis de Abril a Junho]. Diário Oficial da União de 16/05/74 pg. 2918-9

http://www.saude.gov.br./sps/areastecnicas/bucal/dados/fluor/lei605 0.htm <capturado em 05/11/02> 
14. Brasil. Coleção das Leis de 1975: Decreto $n^{\circ} 76.872$ de 22/12/1975.

Brasilia: Departamento de Imprensa Nacional; 1976. [Vol VIII: p 687-8. Atos do Poder Executivo. Decretos de Outubro a Dezembro]. http://www.saude.gov.br./sps/areastecnicas/bucal/dados/fluor/ dec76872.htm <capturado em 05/11/02>

15. Brasil. Ministério da Saúde. Portaria 635 de 26 de dezembro de 1979. Brasilia, DF. CDMS. 1979.

16. Brasil. Constituição da República Federativa do Brasil. Brasilia, CGSenado Federal, 1988.

17. Brasil. Congresso Nacional. Lei Federal $n^{\circ} 8.080$, de 19/09/1990. Diário Oficial da União 20 de set. 1990, p. 18055.

18. Brasil. Ministério da Saúde. Levantamento Epidemiológico em Saúde Bucal: Brasil, Zona Urbana, 1986. Brasilia: Ministério da Saúde, Secretaria Nacional de Programas Especiais de Saúde. Divisão Nacional de Saúde Bucal, 1988.

19. Brasil. Ministério da Saúde. Secretaria de Políticas Públicas de Saúde. Área Técnica da Saúde Bucal. Fluoretação das águas de consumo público no Brasil. Disponivel em htm://www.saude.gov.br/programas/ bucal/inicial.htm: capturado em 29 de março de 2003.

20. Brown HK; McLaren HR; Poplove M. Brantfort - Sarnia - Stratford fluoridation caries study. 1959 report. Canadian Dental Association Journal 1959; 26: 131-42.

21. Buendia OC. Situação atual da fluoretação de águas de abastecimento público no Estado de São Paulo. Rev Saúde Pública 1983; 17: 226-32. 
22. Buendia OC. Fluoretação de águas: Manual de orientação pratica. American Méd Editora Ltda: 1996.

23. Burt BA, Eklund SA, Loeschw WJ. Dental benefits of limited exposure to fluoridete water in childhood. J Dent Res. 1986: 61: 1322-5.

24. Burt BA. Cost effectiveness of caries prevention in dental public health. J. Public Health Dentistry 1989; 49 (Special Issue): 256-8.

25. Burt BA. Trends in caries prevalence in North American children Int Dent J. $1994 ; 44: 403-13$.

26. Burton VJ, Rob MI, Craig GG, Lawson JS. Changes in the caries experience of 12 years old Sidney school children between 1963 and 1982. Med J Aust. 1984; 140: 405-7.

27. Calvo MCM. Situação da fluoretação de águas de abastecimento público no Estado de São Paulo. Brasil, São Paulo; 1996. [Dissertação de Mestrado - Faculdade de Saúde Pública da Universidade de São Paulo].

28. Campatelli V. La carie dentaria nell'infonzia. apud Finn SB. Prevalence of dental caries. In: Toverud, $G$ et al. A survey of the literature of dental caries. Whashinton, DC, National Academy of Sciences/ National Research Council. 1952; 117-73.

29. Carr SM, Dooland MB, Roder DM. Fluoridation II: An interim economic analysis. Australian Dental Journal 1980; 25(6): 343-8.

30. Chaves MM. Flúor e cárie dentária. Revista Brasileira de Odontologia 1953a; Número Especial: 03-66. 
31. Chaves MM, Frankel JM, Melo $C$. Fluoretação de águas de abastecimento público para prevenção parcial da cárie dentária. Rev APCD 1953b; 7(2): 27-33.

32. Chaves MM. Odontologia Social. $3^{\circ}$ ed. Rio de Janeiro: Artes Médicas; 1986.

33. [CDC] Centers for Disease Control and Prevention. Water fluoridation: A Manual for Engineers and Technicians. CDC, 1991.

34. [CDC] Centers for Disease Control and Prevention. Engineering and administrative recommendation for water fluoridation. MMWR 1995; 44(RR-13).

35. [CDC] Centers for Disease Control and Prevention. Achievements in public health, 1990 - 1999: Fluoridation of drinking water to prevent dental caries. MMWR 1999; 48: 933-40.

36. [CDC] Centers for Disease Control and Prevention. Populations receiving optimally fluoridated public drinking water - United States, 2000. MMWR 2002; 51(07): 144-7.

37. Cox GJ. New knowledge of fluorine in relation to dental caries. Journal of American Water Works Association 1939; 31(1): 926.

38. [CRO-SP] Conselho Regional de Odontologia de São Paulo. Situação atual da fluoretação da água de abastecimento público do Estado de São Paulo - 2001. São Paulo: 2001. [relatório técnico].

39. Cohn A, Elias PE. (cord)et al. O público e o privado na saúde o PAS em São Paulo. São Paulo: Cortez: CEDEC, 1999. 
40. Cunninghan $G$. Experience of a school dental clinic: Cambridge dental institute. apud Finn SB. Prevalence of dental caries. In: Toverud, $G$ et al. A survey of the literature of dental caries. Whashinton, DC, National Academy of Sciences/ National Research Council. 1952; 117-73.

41. Cury JA. Representatividade dos dentifricios fluoretados no mercado brasileiro e sua confiabilidade como método preventivo. São Paulo: ABOPREV. 1989.

42. Cury JA. Carie e creme dental. J Aboprev. 1998; 9(espec): 2.

43. Cury JA. Uso de Flúor e o controle da cárie como doença. in: Baratieri LN, Monteiro S, Andrada MAC, Vieira LCC, Ritter AV, Cardoso AC. Odontologia Restauradora - Fundamentos e possibilidade. São Paulo: Santos; 2001 p 34-68.

44. Cury JA, Tabchoury CPM, Determination of appropriate exposure to fluoride in non-EME countries in the future. J Appl Oral Sci 2003; 11(2): 83-95.

45. Davies GN. Fluoride in the prevention of dental caries, a tentative costbenefit analysis. British Dental Journal 1973; 135(3): 132-4.

46. Dean HT (1933). Distribution of mottled enamel in the United States. In: McClure FJ (Editor). Fluoride drinking waters. Maryland: USPHS; 1962; 11-23.

47. Dean HT (1934). Classification of mottled enamel diagnosis. In: McClure FJ (Editor). Fluoride drinking waters. Maryland: USPHS; 1962; 23-6.

48. Doessel DP. Cost-benefit analysis of water fluoridation in Townsville, Australia. Community Dent Oral Epidemiol 1985; 13(1): 19-22. 
49. Dowell TB. The economics of fluoridation. British Dental Journal 1976; 140: $103-6$.

50. Downer MC. Caries prevalence in the United Kingdom. Int Dent J. 1994; 44: $365-70$.

51. Downer MC. Caries experience and sucrose availability: an analysis of the relationship in the United Kingdom over fifty years Community Dental Health. 1999; 16: 18-21.

52. Duram A, Del Passo E. Novo e prático índice para estimar a prevalência da cárie dentária em odontologia sanitária. Rev. Ass. Paul. Cirug. Dent, 1970; mar/abr, 24(2): 74-84.

53. Fenchel A. (1893) Die karies frequenz der Zahne hamburgiscer kinder. apud Finn SB. Prevalence of dental caries. In: Toverud, $G$ et al. A survey of the literature of dental caries. Whashinton, DC, National Academy of Sciences/ National Research Council. 1952; 117-73.

54. Frazão P, Antunes JLF, Narvai PC. Perda dentária precoce em adultos de 35 a 44 anos de idade, Estado de São Paulo, Brasil, 1998. Rev Bras Epidemiol. 2003; 6(1): 49-57.

55. Freitas SFT. História social da cárie dentária. Bauru, SP: EDUSC; 2001.

56. Freire PS, Freire AS, Resultados de sete anos de fluoretação de águas no Brasil. Rev. Serv. Esp. Saúde Pub. 1961; jun 11 (2): 633-45.

57. Freysleben GR, Peres MAA, Marcenes W. Prevalência de cárie e CPO-D médio em escolares de doze e treze anos de idade nos anos de 1971 e 1997, região Sul do Brasil. Rev Saúde Pública 2000; 34(3): 304-8. 
58. [FSP-USP] Faculdade de Saúde Pública da Universidade de São Paulo, Levantamento Epidemiológico em Saúde Bucal: Santos, SP, 1995. São Paulo, FSP-USP, 1995; [Relatório].

59. [FSP-USP] Faculdade de Saúde Pública da Universidade de São Paulo, Secretaria de Saúde de São Vivente, Levantamento Epidemiológico em Saúde Bucal: São Vicente, SP, 1996. São Vicente, FSP-USP, 1996; [Relatório].

60. Gandra YR. Contribuição para o conhecimento do teor de flúor de águas do Estado de São Paulo - Significação sanitária do problema. São Paulo; 1951. [Tese de Livre Docência - Faculdade de Higiene e Saúde Pública da Universidade de São Paulo].

61. Garcia Al. Caries incidence and cost of preventive programs. Journal Health Dental 1989; 49 (Special Issue): 259-271.

62. Griffin SO, Jones K, Tomar SL. An economic evaluation of community water fluoradation. J Public Health Dentistry 2001; 61(2): 78-86.

63. Gruebel AO. A measurement of dental caries prevalence and treatment service for deciduous teeth. J Dent Res. 1944: 23: 163.

64. Guilhermin V. (1895) Untersuchungen der Zahne von schulkinder Schweiz. apud Finn SB. Prevalence of dental caries. In: Toverud, G et al. A survey of the literature of dental caries. Whashinton, DC, National Academy of Sciences/ National Research Council. 1952; 117-73.

65. Haddix AC, Teutsch SM, Shaffer P, Dunet D. Prevention effectiveness. New York: Oxford University Press; 1996: 109. 
66. Hipócrates. Ares, águas e lugares. In : Organización Panamericana de la Salud. El desafio de la epidemiologia: problemas y lecturas seleccionadas. Washington: OPS:1988; 18-9. (Publicação Científica 505).

67. Horowitz HS, Heifetz SB. Methods for assessing the cost-effectiveness of caries preventive agents and procedures. Int Dental Journal 1979; 29(2): 106-17.

68. Hunt RJ, Eldredge JB, Beck JD. Effect of residence in a fluoridated community on the incidence of coronal and root caries in an older adult population. J Pub Health Dent 1989; 49(3): 138-41.

69. Hunter PBV, Henderson MBN. The oral health of 8 and 9 year old children in Timaru e Oamaru. N.Z. Dent Journal 1982; 78: 94.

70. [IBGE] Instituto Brasileiro de Geografia e Estatística. Censo Demográfico São Paulo, 1970. Rio de Janeiro, IBGE, 1974 p 398-406.

71. [IBGE] Instituto Brasileiro de Geografia e Estatística. Censo Demográfico São Paulo, 1980. Rio de Janeiro, IBGE, 1984 p 180-6.

72. [IBGE] Instituto Brasileiro de Geografia e Estatística. Censo Demográfico São Paulo, 1991. Rio de Janeiro, IBGE, 1994 p 83-95.

73. [IBGE] Instituto Brasileiro de Geografia e Estatística. Sistema IBGE de Recuperação Automática - SIDRA. 2001, http://www.sidra.ibge.gov.br/.

74. [IBGE] Instituto Brasileiro de Geografia e Estatística. Atlas de Saneamento. 2004, http://uww.ibge.gov.br/<capturado em 13/04/2004>. 
75. [IPC - FIPE] Índice de Preços Índice de Preços ao Consumidos, da Fundação Instituto de Pesquisa Econômica / USP 2004, http://www. ocaixa.com.br/banco de dados/ipe-fipe.htm <capturado em 20/02/2004>.

76. Keyes PH. Recent advances in dental research. Bacteriology. Int Dent J. 1962; des, 12 (4): 443-64.

77. Klein H, Palmer CE. Dental caries in American indian children. Public Health Bulletin, 1937; Des. (239): 1-53.

78. Klein H, Palmer CE, Knutson JW. Studies on dental caries. I. Dental status and dental needa of elementary school children. Publ. Health. Rep. 1938; mar, 53 (19): 751-65.

79. Knutson JW. Et al. The effect of topically applied sodium fluoride on dental caries experience. IV report of findings with two four and six applications. Publ. Health Rep. 1946; mar. 62(12): 425-30.

80. Knutson JW. Simplified procedure for the collection of basic data for planning appraisal. J. Amer. Publ. Health Ass. 1947; 37: 1439.

81. Krohn C. Kinderzahnpflege. apud Finn SB. Prevalence of dental caries. In: Toverud, $G$ et al. A survey of the literature of dental caries. Whashinton, DC, National Academy of Sciences/ National Research Council. 1952; 117-73.

82. Laurenti R, Mello Jorge MHP, Lebrão ML, Gotlieb SLD. Estatisticas de Saúde. 2ed. São Paulo: EPU; 198. p.31-7.

83. Lima YBO, Cury JA. Ingestão de flúor por crianças pela água e dentifrício Rev Saúde Pública 2001; 35(6): 576-81. 
84. Luce FA. Fluoruracion de lãs águas em Brasil. $65^{\circ}$ Congresso Odontológico Mundial Anual de la Federation Dentária Internacional Toronto, Canadá, 1977.

85. Maier FJ. Aspectos de ingeniería de la fluoración del agua. Boletín de la Oficina Sanitaria Panamericana 1965; 59(3): 208-11.

86. Maier FJ. Las aportaciones de la ingeniería al progreso de la fluoración. Eoletín de la Oficina Sanitaria Panamericana 1970; 68(6): 495-502.

87. Maltz $M$, Silva BB, Relação entre cárie, gengivite e fluorose e nivel socioeconômico em escolares. Rev Saúde Pública 2001; 35(2): 170-6.

88. Manau C, Cuenca E, Martinez-Carretero J, Salleras L. Economic evaluation of community programs for the prevention of dental caries in Catalonia, Spain. Community Dent Oral Epidemiol 1987; 15(6): 297-300.

89. Manfredini MA. Santos: cidade sorriso. in: Cadernos de Resumos do ENATESPO XII - Congresso Brasileiro de Saúde Bucal Coletiva; Curitiba; 1996.p 8.

90. Marcenes W, Bonecker MJS. Aspectos epidemiológicos e sociais das doenças bucais in: Buischi YP. (org.) Promoção de Saúde Bucal na Clinica Odontológica. São Paulo, Artes Médicas, 2000; p 77-98.

91. McCombie F. Cost-effectiveness considerations in planning a preventive dental program for British Columbia. Int Dental Journal 1979; 29: 12536. 
92. McKay FS. The establishment of a definite relation between enamel that is defective in structure, as mottled enamel, and the liability to decay. Dental Cosmos 1929; 71(8): 747-55.

93. Ministério da Saúde. Secretaria de Políticas Especiais de Saúde. Area Técnica de Saúde Bucal. Levantamento epidemiológico em saúde bucal - 1996: primeira etapa - Cárie Dental, [on line] . Disponivel em <http:// www..datasus.gov.br/cgi/sbucal/sbdescr.htm> [2002 out 17].

94. Moore WJ, Corbert ME. The distribution of dental caries in ancient British populations - II Iron age Romano-British and Medieval periods. Caries Research 1973; 7: 139.

95. Munblatt MA. A critical study of the incidence of dental caries in children. Dent. Cosmos. 1933; june, 75(6): 592-609.

96. Murray JJ. O uso correto de fluoretos na saúde pública. São Paulo, Organização Mundial da Saúde / Ed Santos, 1992.

97. Nadanovsky P. O declínio da Carie in: Pinto VG. Saúde bucal coletiva. São Paulo, Ed Santos, 2000; p 341-51.

98. Narvai PC, Castellanos RA. Levantamento das condiçōes de saúde bucal - Estado de São Paulo, 1998: Caderno de Instruções. São Paulo: Universidade de São Paulo - Faculdade de Saúde Pública - Núcleo de Estudos e Pesquisas de Sistemas de Saúde, 1998.

99. Narvai PC; Fluoretação das águas: razōes para prosseguir. São Paulo: FUNDAPISES-SP; 1997.

100. Narvai PC. Cárie dentária e flúor: uma relação do século $X X$. Ciência \& Saúde Coletiva 2000; 5 (2): 381-92. 
101. Narvai $P C$, Castellanos RA, Frazão $P$. Prevalência de carie em dentes permanentes de escolares do município de São Paulo, SP 1970-1996. Rev Saúde Pública 2000b; 34(2): 198-200.

102. Narvai PC. Fluoretação de água: Heterocontrole no municipio de São Paulo no periodo 1990-1999. Rev Bras Odont Saúde Coletiva 2000c; 1(2): 50-6.

103. Narvai PC. Vigilância sanitária da fluoretação das águas de abastecimento público no município de São Paulo, Brasil, no período 1990-1999. São Paulo, 2001 [Tese de Livre Docência Faculdade de Saúde Pública da Universidade de São Paulo].

104. Nelson W, Swint JM. Cost-benefit analysis of fluoridation in Houston, Texas. J Public Health Dentistry 1976; 36(2): 88-95.

105. Newbrun E. Effectiveness of water fluoridation. J Public Health Dentistry 1989; 49 (5 Special Issue): 279-89.

106. Newbrun E. Problems in caries diagnosis Int Dent $J$ 1993; 43: 13342.

107. Newbrun $E$. The fluoridation war: a scientific dispute or a religious argument? J Public Health Dentistry 1996; 56(5-special issue): 246-51.

108. Niessen L, Douglass CW. Theoretical considerations in applying benefit-cost and cost-effectiveness analyses to preventive dental programs. J Public Health Dentistry 1984; 44(4):156-68. 
109. Odenthal (1887) Kariose zahne als eingangspforte infectiosen materials und ursache chroniscer lymphdrusen scwellungen am hales. apud Finn SB. Prevalence of dental caries. In: Toverud, $G$ et al. A survey of the literature of dental caries. Whashinton, DC, National Academy of Sciences/ National Research Council. 1952; 117-73.

110. [OMS] Organização Mundial da Saúde. Levantamento epidemiológico básico de saúde bucal. $3^{\circ} e d$. São Paulo: Santos, 1991.

111. [OMS] Organização Mundial da Saúde. Levantamentos básicos em saúde bucal. $4^{\circ}$ ed. São Paulo: Santos, 1999.

112. [OMS] Organização Mundial da Saúde. Fluorides and human health, Genebra: WHO; 1970

113. [OMS] Organização Mundial da Saúde. Appropriate use of fluorides for human health, Genebra: WHO; 1986

114. [OPS] Organización Panamericana de la Salud. Manual prático de fluoretação de água potável. Washington: OPS/OMS; 1975. [Doc HP/DH/31/P].

115. [OPS] Organización Panamericana de la Salud. Guias para la calidad del agua potable. Washington: OPS/OMS; 1987.

116. Oscarson N, Kallestal C, Fjelddahl A, Lindholm L. Cost-effectiveness of different caries preventive measures in a high-risc population of swedish adolescents. Community Dent Oral Epidemiol. 2003; 31: 16878. 
117. Pereira MG. Epidemiologia teoria e prática. Rio de Janeiro: Guanabara-Koogan; 2000.

118. Peres MAA, Freitas ST, Lacerda J, Calvo MCM. Prevalência de cárie dentária na população de 3 a 12 anos de idade no municipio de Florianópolis, SC, Brasil, 1995. in: Cadernos de Resumos do ENATESPO XII - Congresso Brasileiro de Saúde Bucal Coletiva; Curitiba; 1996.p 31.

119. Peres MAA, Traebert JL, Marcenes WC. Levantamento epidemiológico em saúde bucal em escolares de 6 a 12 anos de idade no município de Blumenau, SC 1998 [Relatório final] Blumenau; 1998.

120. Peres KGA, Bastos JRM, Latorre MRDO, Severidade de cáries em crianças com aspectos sociais e comportamentais. Rev Saúde Pública 2000; 34(4): 402-8.

121. Petersson HG, Bratthall $D$. The caries decline: a review of reviews Eur J Oral Sci 1996; 104: 436-43.

122. Pinto VG. Revisão sobre uso e segurança do flúor. RGO 1993; 41(5): 263-6.

123. Pinto VG. Estudo epidemiológico sobre prevalência da cárie dental em crianças de 3 a 14 anos, Brasil 1993. Brasilia: Sesi-DN; 1996.

124. Pinto VG. Saúde bucal coletiva. São Paulo: Editora Santos; 2000.

125. PNUD/ONU Human development report 2000. New York, Oxford University Press, 2002. 
126. Ribeiro PC. Cotação do Dólar Comercial Venda. Gazeta Mercantil / Valor Econômico.

http://unw.geocities.com/Paris/Rue/5045/DOLARM.HTM <capturado em 24/01/2004>.

127. Ringelberg ML, Allen SJ, Brown LJ. Cost of Fluoridation: 44 Florida Communities. J. Public Health Dentistry 1992; 52(2): 75-80.

128. Ripa LW. A half-century of community water fluoridation in the United States: review and commentary. J. Public Health Dent 1993; 53:17-62.

129. Rosa AGF. Características epidemiológicas da cárie dental na dentição permanente de escolares do grupo etário de 7 a 14 anos no Estado de São Paulo. São Paulo, 1987. [Tese de Doutorado Faculdade de Saúde Pública, Universidade de São Paulo].

130. Sá ENC, Simioni AMC, Ramos CRS, et al. Éxodo forçado de servidores da Secretaria Municipal de Saúde de São Paulo em decorrência da implantação do PAS - Plano de atendimento a saúde: São Paulo: USP-FSP; 1997 [série monográfica nº - eixo política, planejamento e administração].

131. [SABESP] Companhia de Saneamento Básico do Estado de São Paulo, Sistema de abastecimento de águas da cidade de São Paulo, 2003. http://umw.sabesp.com.br/html/areas-de-atuacao/detalheasp?municipio/htm/. <capturado em 24/06/2003>

132. Sampaio FC, Ramm von der fehr $F$, Arneherg $P$, Petrucci Gigante $D$, Hatloy A. Dental Fluorosis and Nutritional status of 6 to 11 - year - old. Children living in rural areas of Paraiba, Brasil. Caries Res. 1999; 33 : 66-73. 
133. [SANEPAR] Secretaria de Estado de Saúde do Paraná. Custo da fluoretação das águas de abastecimento Estado do Paraná em 2000. http://uww.saude.pr.gov.br/bucal/fluoretacao/custo-fluoretacao.htm <capturado em 10/10/2003>

134. São Paulo. Lei Estadual n 4.637 de 18 de abril de 1958. São Paulo, SP.

135. São Paulo (Município). Secretaria Municipal da Educação.

Departamento de Saúde Escolar. Levantamento epidemiológico de cárie dentária em escolares de São Paulo, em 1983-1984. In: Proposta de um programa de integração da assistência Odontológica no município de São Paulo. São Paulo: mimeo; 1985.

136. São Paulo. Secretária Municipal da Saúde. Centro de Epidemiologia, Pesquisa e Informação. Assessoria de Saúde Bucal. Sistema municipal de vigilância sanitária da fluoretação de águas de abastecimento público Relatório 1990. São Paulo: mimeo;1990.

137. São Paulo (Município) Secretaria Municipal da Saúde, Coordenadoria de Saúde Bucal - COAS/SMS, Divisão Municipal de abastecimento DIMA, Sistema de Vigilância Sanitária de Fluoretação de águas de abastecimento público no município de São Paulo. 2000. São Paulo: PMSP-SMS; 2001 [Relatório anual].

138. São Paulo (Município) Secretaria Municipal da Saúde, Coordenação de Desenvolvimento da Gestão Descentralizada - COGest, Sistema de Vigilância Sanitária de Fluoretação de águas de abastecimento público no município de São Paulo. 2001. São Paulo: PMSP- SMS; 2002 [Relatório anual]. 
139. São Paulo (Município) Secretaria Municipal da Saúde, Coordenação de Desenvolvimento da Gestão Descentralizada - COGest, Sistema de Vigilância Sanitária de Fluoretação de águas de abastecimento público no municipio de São Paulo. 2002. São Paulo: PMSP- SMS; 2003 [Relatório anual].

140. São Paulo (Municipio) Secretaria Municipal da Saúde, Coordenação de Desenvolvimento da Gestão Descentralizada - COGest, Sistema de Vigilância Sanitária de Fluoretação de águas de abastecimento público no município de São Paulo. 2003. São Paulo: PMSP- SMS; 2004 [Relatório anual].

141. Schnaider Filho DA, Prado IT, Narvai PC, Barbosa SR. Fluoretação da água - Como fazer a vigilância sanitária? Cadernos de Saúde Bucal 1992; 2. Rio de Janeiro: Rede CEDROS.

142. [SEADE] Fundação SEADE. Perfil Municipal de São Paulo http://www.seade.gov.br/perfil/index.htmt <capturado em 18/08/2003 e em 08/10/2003>

143. Secretaria de Estado da Saúde de São Paulo. Universidade de São Paulo. Faculdade de Saúde Pública. Levantamento epidemiológico da cárie dentária, oclusopatias e fluorose dentária, em crianças de 5 a 12 anos de idade, em escolas públicas e privadas do município de São Paulo, em 1996. São Paulo: FSP/USP; 1997.

144. Secretaria de Estado da Saúde de São Paulo. Universidade de São Paulo. Faculdade de Saúde Pública. Levantamento epidemiológico em saúde bucal - estado de São Paulo, 1998. São Paulo: FSP/USP; 1999. 
145. Secretaria de Estado da Saúde de São Paulo. Universidade de São Paulo. Faculdade de Saúde Pública. Condiçōes de saúde bucal no estado de São Paulo em 2002. São Paulo: SES-SP; 2002.

146. Scheinin A. et al. Prevalence of dental caries and dental health in relation to variable concentration of fluoride in drinking water: a clinical study on finnish school children. Acta. Odont. Scan. 1964; 22 : 229-54.

147. Sheiham A. Changing tends in dental caries. Int J Epidemiol. 1984;13: 142-7.

148. Sheiham $A$. Why free sugar consumption should be below $15 \mathrm{Kg}$ per person per year in industrialized countries the dental evidence. Br Dent. $1991 ; 171: 63-5$.

149. Silva MC. Crise faz a Sabesp reduzir flúor na água OESP - Jornal O Estado de São Paulo; São Paulo 03/09/1992.

150. [SNVS] Secretaria Nacional de Saúde de Vigilância Sanitária. Portaria $n^{\circ} 22$ de dezembro de 1989 - Diário Oficial da União 22/12/1989 pg 24111.

http://umw.saude.gov.br/sps/areastecnicas/bucal/dados/fluor/port22vig.ht p <capturado em 05/11/02>.

151. Stamm JW, Banting DW, Imrey PB. Adult root caries survey of two similar communities with contrasting nature water fluoride levels. J Am Dent Assoc. 1990; 120(2): 143-9.

152. Souza JMP. Índice CPO-D, indice de ataque, número de dentes irrompidos: Comportamento em escolares do Município de São Paulo, São Paulo, 1970. [Tese de Doutorado - Faculdade de Saúde Pública, Universidade de São Paulo]. 
153. [TDH] Texas Department of Health. Water Fluoridation Costs in Texas, House concurrent resolution 145, Texas $75^{\text {th }}$ Legislature, May, 2000.

154. Thylstrup A, Ferjeskov O. O Tratado de Cariologia. Ed.Cultura Médica: Rio de Janeiro, 1988.

155. Thylstrup A, Ferjeskov O. Cariologia Clinica. Ed.Santos: São Paulo $2^{\circ}$ ed, 1995.

156. Toro-Freire C. Dental caries in schoolchildren. apud Finn SB. Prevalence of dental caries. In: Toverud, $G$ et al. A survey of the literature of dental caries. Whashinton, DC, National Academy of Sciences/ National Research Council. 1952; 117-73.

157. Treasure ET, Dever JG. Relationship of caries with socioeconomic status in 14-year-old children from communities with different fluoride histories. Community Dent Oral Epidemiol. 1994: 22: 226-30.

158. Ugá MAD. Instrumentos de avaliaçăo econômica de serviços de saúde: alcances e limitações. In : Piola SF, Vianna SM. Economia da saúde: conceito e contribuição para a gestão da saúde. Brasília, IPEA;1995.

159. Vasconcelos $\mathrm{JL}$. Sugestões para as atividades de um programa dentário escolar. Rev. Ass. Paul. Cirurg. Dent. 1959; jul-ag 13(4): $193-$ 208.

160. Viegas AR. Odontologia sanitária - aspectos preventivos da cárie dentária. São Paulo: Massao Ohno-USP; 1961. 
161. Viegas $Y$, Viegas $A R$. Análise dos dados de prevalência de cárie dental na cidade de Campinas, SP Brasil, depois de dez anos de fluoretação da água de abastecimento público. Rev. Saúde Pública. 1974; 8: 399-409.

162. Viegas $Y$, Viegas $A R$. Prevalência de cárie dental na cidade de Campinas, SP, Brasil, depois de 14 anos de fluoretação da água de abastecimento público. Rev Ass Paul Cirurg Dent 1985; 39: 272-82.

163. Viegas $A R$, Viegas $Y$, Castellanos RA, Rosa AGF. Fluoretação da água de abastecimento público. Rev Ass Paul Cirurg Dent 1987; 41(1): 202-4.

164. Viegas $Y$, Viegas AR. Prevalência de cárie dental em Barretos, SP, Brasil, após dezesseis anos de fluoretação da água de abastecimento público. Rev Saúde Pública 1988; 22(1): 25-35.

165. Weinstein MC, Stason WB. Foundation of cost-effectiveness analysis for health and medical practices. New Engl Journal Med 1977; 296 (13): 716-21.

166. Weyne SC. A construção do paradigma de promoção de saúde: Um desafio para as novas geraçōes. in: Kriger L. (org.) Promoção de Saúde Bucal. São Paulo: Artes Medicas 1997; p 1-26.

167. White BA, Antczak-Bouckoms AA, Weinstein MC. Issues in the economic of community water fluoritation. J Dental Education 1989; 53(11): 646-57.

168. World Health Organization, Oral health surveys, basic methods. $4^{\circ} \mathrm{ed}$. Geneva: OMS, 1997. 
169. Wright JC, Bates MN, Cutress $T$, Lee $M$. The cost-effectiveness of fluoridating water supplies in New Zealand. Australian and New Zealand J Public Health 2001; 25(2): 170-8. 


\section{ANEXOS}




\section{ANEXO 1}

Roteiro para Entrevista:

A) CUSTO DO ÁCIDO FLÚOR-SILÍCICO.

1- Sistemas de tratamento de água na cidade de São Paulo

CSP - Cidade de São Paulo

GSP - Grande São Paulo

2- Volume de água distribuido por cada sistema.

3- Tipo de flúor utilizado em cada sistema.

4- Quantidade de flúor gasto por sistema/dia.

5- Tanques de estoques, número e capacidade

6- Capacidade de estocagem do produto

\begin{tabular}{|l|l|l|l|l|l|}
\hline & Local & Vazão & $\begin{array}{c}\text { AFS } \\
\text { Tonelada }\end{array}$ & $\begin{array}{c}\text { Tanque } \\
\text { Armaz. }\end{array}$ & Estoque \\
\hline $\begin{array}{l}\text { Guaraú- } \\
\text { Cantareira }\end{array}$ & & & & & \\
\hline Guarapiranga & & & & & \\
\hline AltoTietê & & & & & \\
\hline Rio claro & & & & & \\
\hline $\begin{array}{l}\text { Ribeirão da } \\
\text { Estiva }\end{array}$ & & & & & \\
\hline Rio Grande & & & & & \\
\hline Alto Cotia & & & & & \\
\hline Baixo Cotia & & & & & \\
\hline
\end{tabular}

7 - Equipamentos necessários para:

> Estocar e armazenar;

$>$ Dosar o produto;

- Controlar e verificar a dosagem; 
8 - Armazenamento

- Equipamentos utilizados para armazenar e estocar o flúor

- Consumo dia de flúor

- Estocagem do produto

- Armazenamento ETA

- Armazenamento Central

- Compra conforme a necessidade

9 - Flúor

- Quantidade de Flüor natural

- Quantidade de flúor incorporado (flúor adicionado na ETA)

- Concentração ideal de flúor

10 - Dosagem do produto

- Equipamento utilizado para dosar o produto

- Mecânico

- Bomba dosadoras de vazão

- Controle da Dosagem

- Onde é realizado

- Quando é realizado (periodicidade)

- Como é realizado

- Quem realiza

\section{B ) CUSTOS}

1- Relatório com a planilha de despesas - ano - mês, etc.

2- Gasto na compra do Flúor?

3- Empresas que fornecem o produto?

4- Mecanismos adotados pela compra do produto - licitação pública de preços?

5- Por ser sub produto da indústria de fertilizantes há sazonalidade na produção do produto, esta sazonolidade se reflete na composição do preço do produto? 
6- Cada ETA faz sua própria compra ou há uma compra centralizada e distribuída?

7- O produto tem uma compra anual ou conforme a necessidade?

8- Qual o tempo de duração dos estoques reguladores?

\section{C) PROBLEMAS}

1. Há falta do produto no mercado?

2. Quando falta como o problema é solucionado para não interromper a fluoretação das águas?

D) OUTROS CUSTOS

1- Despesa de investimento inicial? (compra de equipamentos)

2- Despesas periódicas? (compra de tanque de armazenamento)

3- Despesas momentâneas? (troca de bomba)

4- Despesas de avanços tecnológicos? (medidores digitais)

5- Despesas com treinamento ae $\mathrm{RH}$ ?

$>N^{\circ}$ de funcionários para controle bomba

- Qualificação e salário.

$>N^{\circ}$ de funcionários para o controle químico dos produtos

- Qualificação e salário;

- Tempo exigido para o controle;

- Periodicidade dos testes;

$>$ Treinamento inicial ?

$>$ Treinamento de manutenção?

6- Despesas com laboratórios e vidrarias? 
ANEXO 2

Quadro 1 - Consumo de ácido fluorsilícico, segundo meses do ano, no período de 1985 a 2003 e o volume de água tratada na ETA Guaraú no periodo de 1974 a 2003, Săo Paulo.

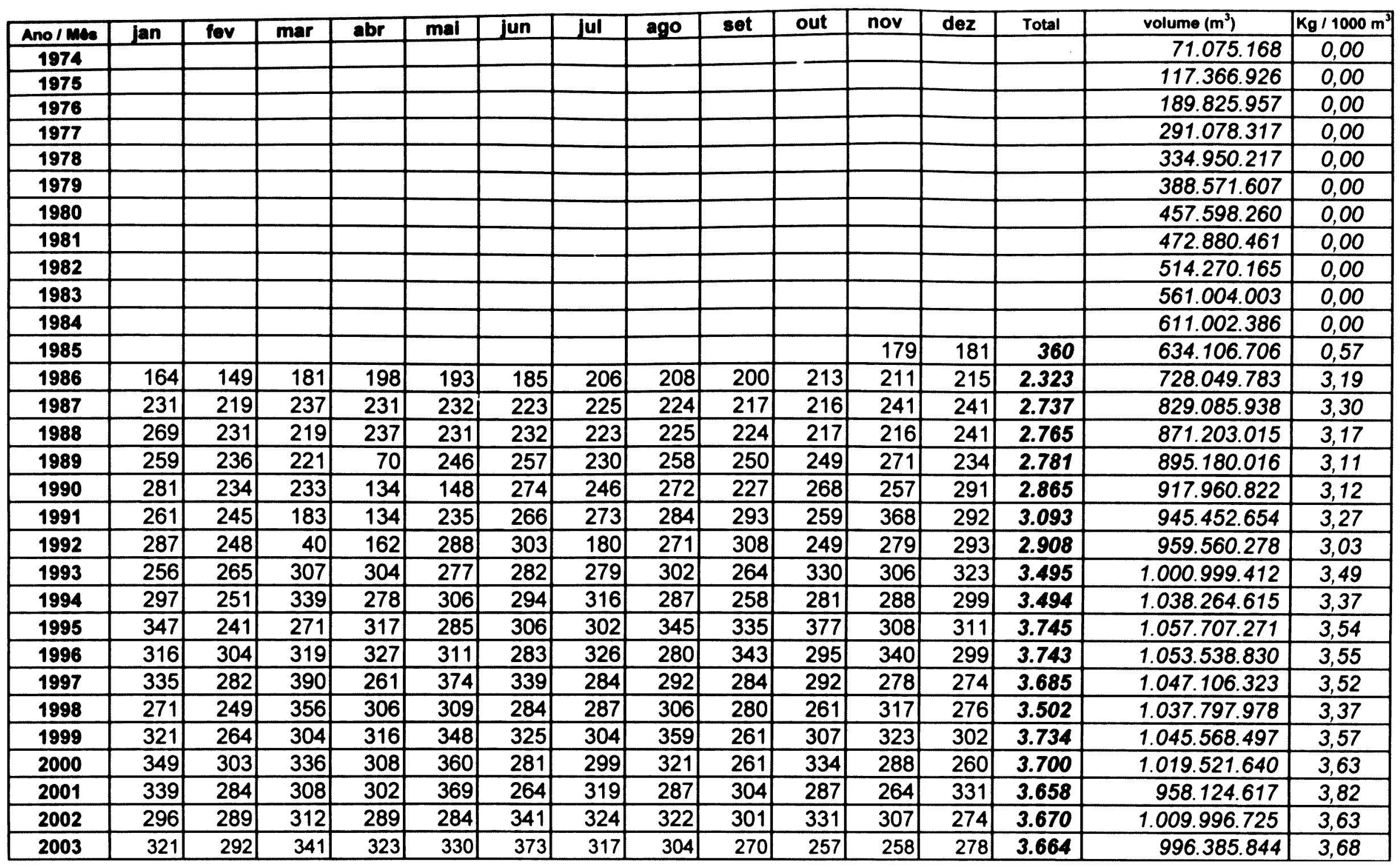




\section{Anexo 3}

\section{Cotação do Dólar Americano Médio Comercial}

\begin{tabular}{|c|c|c|c|c|c|c|c|c|c|c|c|c|}
\hline & JAN & FEV & MAR & ABR & MAI & JUN & JUL & AGO & SET & OUT & NOV & DEZ \\
\hline 1985 & 3351,42 & 3756,93 & 4162,13 & 4709,67 & 5212,48 & 5728,67 & 6222,58 & 6706,45 & 7462,17 & 8181,94 & 8913,33 & 9950,00 \\
\hline 1986 & 11243,6 & 12966,1 & 13,84 & 13,84 & 13,84 & 13,84 & 13,84 & 13,84 & 13,84 & 13,97 & 14,11 & 14,56 \\
\hline 1987 & 15,63 & 18,08 & 20,88 & 23,67 & 30,45 & 39,36 & 44,89 & 47,10 & 49,82 & 53,64 & 59,16 & 67,72 \\
\hline 1988 & 77,38 & 91,14 & 107,45 & 124,81 & 150,88 & 177,88 & 216,01 & 267,99 & 323,40 & 411,75 & 525,77 & 669,11 \\
\hline 1989 & 0,9073 & 1,00 & 1,00 & 1,014 & 1,099 & 1,328 & 1,898 & 2,471 & 3,238 & 4,466 & 6,165 & 9,326 \\
\hline 1990 & 14,206 & 24,117 & 37,341 & 47,868 & 52,190 & 57,190 & 66,524 & 71,846 & 74,904 & 95,165 & 123,130 & 154,240 \\
\hline 1991 & 193,19 & 221,76 & 230,34 & 252,19 & 271,74 & 297,62 & 328,92 & 371,33 & 428,93 & 583,85 & 740,37 & 939,18 \\
\hline 1992 & 1197,4 & 1478,7 & 1814,2 & 2196,8 & 2628,6 & 3149,8 & 3829,2 & 4672,1 & 5771,6 & 7214,9 & 9044,6 & 11150,9 \\
\hline 1993 & 14059,1 & $17868,622469,2$ & 28728,9 & 37040,3 & 48106,5 & 62773,2 & 82,74 & 111,19 & 151,23 & 205,80 & 279,39 \\
\hline
\end{tabular}

\begin{tabular}{|l|l|l|l|l|l|l|l|l|l|l|l|l|}
\hline & JAN & FEV & MAR & ABR & MAI & JUN & JUL & AGO & SET & OUT & NOV & DEZ \\
\hline 1994 & 390,82 & 550,81 & 768,12 & 1109,56 & 1585,48 & 2296,26 & 0,933 & 0,899 & 0,865 & 0,846 & 0,842 & 0,850 \\
\hline 1995 & 0,847 & 0,841 & 0,889 & 0,912 & 0,897 & 0,914 & 0,929 & 0,942 & 0,953 & 0,960 & 0,963 & 0,968 \\
\hline 1996 & 0,975 & 0,981 & 0,986 & 0,990 & 0,995 & 1,001 & 1,007 & 1,013 & 1,019 & 1,025 & 1,030 & 1,037 \\
\hline 1997 & 1,043 & 1,049 & 1,057 & 1,061 & 1,068 & 1,075 & 1,081 & 1,088 & 1,0964 & 1,1031 & 1,1098 & 1,1164 \\
\hline 1998 & 1,1237 & 1,1304 & 1,1374 & 1,1443 & 1,1505 & 1,1546 & 1,1615 & 1,1717 & 1,1809 & 1,1884 & 1,1937 & 1,2054 \\
\hline 1999 & 1,5019 & 1,9137 & 1,8968 & 1,6941 & 1,6835 & 1,7654 & 1,8003 & 1,8808 & 1,8981 & 1,9695 & 1,9299 & 1,8428 \\
\hline 2000 & 1,8037 & 1,7753 & 1,7420 & 1,7682 & 1,8279 & 1,8083 & 1,7978 & 1,8092 & 1,8392 & 1,8796 & 1,9480 & 1,9633 \\
\hline 2001 & 1,9545 & 2,0019 & 2,0891 & 2,1925 & 2,2972 & 2,3758 & 2,4660 & 2,5109 & 2,6717 & 2,7402 & 2,5431 & 2,3627 \\
\hline 2002 & 2,3779 & 2,4196 & 2,3466 & 2,3204 & 2,4804 & 2,7140 & 2,9346 & 3,1101 & 3,3420 & 3,8059 & 3,5764 & 3,6257 \\
\hline 2003 & 3,4384 & 3,5908 & 3,4469 & 3,1187 & 2,9557 & 2,8832 & 2,8798 & 3,0025 & 2,9228 & 2,8615 & 2,9138 & 2,9253 \\
\hline
\end{tabular}

Esta página é mantida pelo Prof. Paulo Cezar Ribeiro

Fonte: Gazeta Mercantil / Valor Econômico 


\section{IPC (FIPE)}

\section{Variação \% Mensal}

\begin{tabular}{|l|r|r|r|r|r|}
\hline IPC & 1985 & 1986 & 1987 & 1988 & 1989 \\
\hline JAN & 11,18 & 14,05 & 13,75 & 14,70 & 31,11 \\
\hline FEV & 9,69 & 10,86 & 11,28 & 13,38 & 14,01 \\
\hline MAR & 10,79 & 1,83 & 11,97 & 18,65 & 6,46 \\
\hline ABR & 8,33 & 2,31 & 16,55 & 21,17 & 10,02 \\
\hline MAI & 8,91 & 1,92 & 26,49 & 16,25 & 16,59 \\
\hline JUN & 8,16 & 0,96 & 26,76 & 21,70 & 25,29 \\
\hline JUL & 11,40 & 1,07 & 9,24 & 22,65 & 28,06 \\
\hline AGO & 11,71 & 1,88 & 4,45 & 19,67 & 30,95 \\
\hline SET & 7,62 & 1,43 & 6,73 & 23,60 & 35,83 \\
\hline OUT & 12,09 & 3,08 & 10,17 & 28,48 & 37,29 \\
\hline NOV & 12,76 & 4,43 & 13,40 & 25,77 & 42,96 \\
\hline DEZ & 12,46 & 10,30 & 15,92 & 27,89 & 51,82 \\
\hline ANO & 228,22 & 68,08 & 367,13 & 891,67 & $1.635,85$ \\
\hline
\end{tabular}

\begin{tabular}{|l|r|r|r|r|r|r|r|r|r|r|}
\hline IPC & 1990 & 1991 & 1992 & 1993 & 1994 & 1995 & 1996 & 1997 & 1998 & 1999 \\
\hline JAN & 74,53 & 21,02 & 25,89 & 27,42 & 40,30 & 0,80 & 1,82 & 1,23 & 0,24 & 0,50 \\
\hline FEV & 70,16 & 20,54 & 21,57 & 25,10 & 38,19 & 1,32 & 0,40 & 0,01 & $-0,16$ & 1,41 \\
\hline MAR & 79,11 & 7,48 & 21,74 & 25,16 & 41,94 & 1,92 & 0,23 & 0,21 & $-0,23$ & 0,56 \\
\hline ABR & 20,19 & 7,19 & 22,73 & 28,74 & 46,22 & 2,64 & 1,62 & 0,64 & 0,62 & 0,47 \\
\hline MAI & 8,53 & 5,76 & 22,53 & 29,14 & 45,10 & 1,97 & 1,34 & 0,55 & 0,52 & $-0,37$ \\
\hline JUN & 11,70 & 9,78 & 22,45 & 30,53 & 50,75 & 2,66 & 1,41 & 1,42 & 0,19 & $-0,08$ \\
\hline JUL & 11,31 & 11,30 & 21,10 & 30,89 & 6,95 & 3,72 & 1,31 & 0,11 & $-0,77$ & 1,09 \\
\hline AGO & 11,83 & 14,42 & 23,16 & 33,97 & 1,95 & 1,43 & 0,34 & $-0,76$ & $-1,00$ & 0,74 \\
\hline SET & 13,13 & 16,21 & 24,41 & 34,12 & 0,82 & 0,74 & 0,07 & 0,01 & $-0,66$ & 0,91 \\
\hline OUT & 15,83 & 25,17 & 26,46 & 35,23 & 3,17 & 1,48 & 0,58 & 0,22 & 0,02 & 1,13 \\
\hline NOV & 18,56 & 25,39 & 21,89 & 35,84 & 3,02 & 1,17 & 0,34 & 0,53 & $-0,44$ & 1,48 \\
\hline DEZ & 16,03 & 23,25 & 25,29 & 38,52 & 1,25 & 1,21 & 0,17 & 0,57 & $-0,12$ & 0,49 \\
\hline ANO & $1.639,08$ & 458,61 & $1.129,45$ & $2.49,99$ & 941,25 & 23,17 & 10,04 & 4,83 & $-1,79$ & 8,64 \\
\hline
\end{tabular}




\begin{tabular}{|l|r|r|r|r|}
\hline IPC & 2000 & 2001 & 2002 & 2003 \\
\hline JAN & 0,57 & 0,38 & 0,57 & 2,19 \\
\hline FEV & $-0,23$ & 0,11 & 0,26 & 1,61 \\
\hline MAR & 0,23 & 0,51 & 0,07 & 0,67 \\
\hline ABR & 0,09 & 0,61 & 0,06 & 0,57 \\
\hline MAI & 0,03 & 0,17 & 0,06 & 0,31 \\
\hline JUN & 0,18 & 0,85 & 0,31 & $-0,16$ \\
\hline JUL & 1,40 & 1,21 & 0,67 & $-0,08$ \\
\hline AGO & 1,55 & 1,15 & 1,01 & 0,63 \\
\hline SET & 0,27 & 0,32 & 0,76 & 0,84 \\
\hline OUT & 0,01 & 0,74 & 1,28 & 0,63 \\
\hline NOV & $-0,05$ & 0,61 & 2,65 & 0,27 \\
\hline DEZ & 0,26 & 0,25 & 1,83 & 0,42 \\
\hline ANO & 4,38 & 7,13 & $\mathbf{9 , 9 2}$ & $\mathbf{8 , 1 7}$ \\
\hline
\end{tabular}

Fonte: Fundação Instituto de Pesquisa Econômica (USP) 

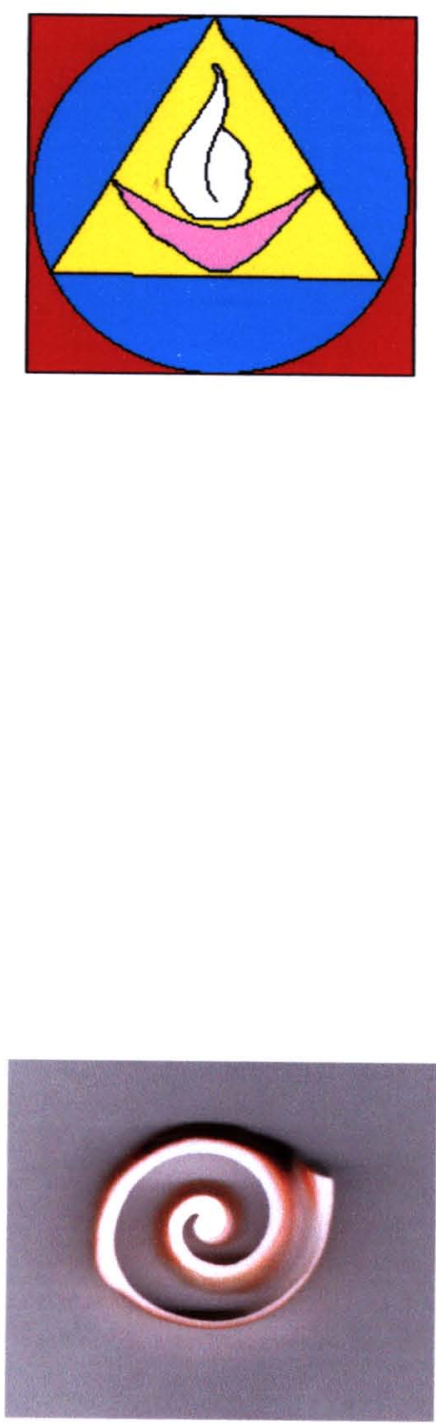